UNIVERSIDADE ESTADUAL PAULISTA

FACULDADE DE MEDICINA DE BOTUCATU

DEPARTAMENTO DE ENFERMAGEM

\title{
DESCRIÇÃO BACTERIÓLOGICA DE BRINQUEDO UTILIZADO EM UNIDADE DE INTERNAÇÃO PEDIÁTRICA
}

Dissertação apresentada ao Programa de Pós Graduação em Enfermagem - Mestrado Profissionalizante - da Faculdade de Medicina de Botucatu da Universidade Estadual Paulista "Júlio de Mesquita Filho" para obtenção do título de Mestre em Enfermagem. 
UNIVERSIDADE ESTADUAL PAULISTA

FACULDADE DE MEDICINA DE BOTUCATU

DEPARTAMENTO DE ENFERMAGEM

\section{DESCRIÇÃO BACTERIÓLOGICA DE BRINQUEDO UTILIZADO EM UNIDADE DE INTERNAÇÃO PEDIÁTRICA}

Dissertação apresentada ao Programa de Pós - Graduação em Enfermagem Mestrado Profissionalizante - da Faculdade de Medicina de Botucatu da Universidade Estadual Paulista "Júlio de Mesquita Filho" para obtenção do título de Mestre em Enfermagem.

Orientadora: Prof $^{\mathrm{a}} \mathrm{Dr}^{\mathrm{a}}$ Ione Corrêa

Aluna: Marcela C. Candido de Almeida 
FICHA CATALOGRÁFICA ELABORADA PELA SEÇÃO TÉCNICA DE AQUISIÇÃO E TRATAMENTO DA INFORMAÇÃO

DIVISÃO TÉCNICA DE BIBLIOTECA E DOCUMENTAÇÃO - CAMPUS DE BOTUCATU - UNESP BIBLIOTECÁRIA RESPONSÁVEL: Selma Maria de Jesus

Almeida, Marcela C. Candido de.

Descrição bacteriológica de brinquedo utilizado em Unidade de internação pediátrica / Marcela C. Candido de Almeida. - Botucatu : [s.n.], 2010.

Dissertação (mestrado) - Faculdade de Medicina de Botucatu, Universidade Estadual Paulista, 2010.

Orientador: Ione Corrêa

Assunto CAPES: 40403009

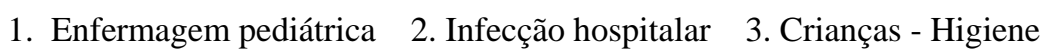


FOLHA DE APROVAÇÃO

\author{
Marcela Cristina Candido de Almeida
}

\title{
DESCRIÇÃO BACTERIÓLOGICA DE BRINQUEDO UTILIZADO EM UNIDADE DE INTERNAÇÃO PEDIÁTRICA
}

Dissertação apresentada ao Programa de Pós Graduação em Enfermagem - Mestrado Profissionalizante - da Faculdade de Medicina de Botucatu da Universidade Estadual Paulista "Júlio de Mesquita Filho" para obtenção do título de Mestre em Enfermagem

Aprovada em:

\section{Banca Examinadora}

$\operatorname{Prof}^{a} \operatorname{Dr}^{a}$ Ione Corrêa: Instituição: Faculdade de Medicina de Botucatu.

Julgamento: Assinatura:

$\operatorname{Prof}^{a} \operatorname{Dr}^{a}$ Ilda de Gody: Faculdade de Medicina de Botucatu.

Julgamento Assinatura:

Prof $^{a} \operatorname{Dr}^{a}$ Silvana Denofre Carvalho Instituição: Universidade Estadual de Campinas. Julgamento: Assinatura: 
Dedicatária

A Dens, que sempre se faz presente em minha vida...

À nassa Nina que esteve a tempa tada da mew lada, nas madrugadas intermináueis...

Vacê está sempre em mew caraçãa...

Aas meus pais par acreditarem em mim e sempre incentivarem a mew crescimenta espiritual e prafissianal... Mãe, abrigada pelas araçães...

Pai, abrigada par nãa medir esfarças para nas ver felizes...

Saw a resultada da amar de vacês par $\operatorname{mim} \ldots$ 
Dedicatária

À minha "ermã" a qual me argulha dizer minha alma gêmea...

Pelas pensamentas pasitivas e pela farça durante minha trajetária...

Aa mew namarada, Yasé Xenrique, pela campreensãa das períadas em que me ausentei e nãa pude ficar aa sew lada...

Aa mew avâ (in memariam). Tenha certeza de que vacê estaria muita argulhasa...

A minha wavazinha (in memariam). Sempre amada. 
Agradecimenta Especial

A minha arientadara, Praf $\mathscr{D}_{r}{ }^{a}$ gane Carrêa, pela dispasiçãa em ensinar-me, acreditanda que en sempre padia mais e mais...

Agradeça-lhe par me fazer perceber que passa ir mais lange...

"A mente que se abre a uma nava ideia jamais valtará ao sew tamanha ariginal..."

(Albert Einstein) 
Agradecimentas

À FUNDUNESP pela cancessãa de famenta à pesquisa,

A tadas as professares da cursa de Pás-Craduaçãa em Enfermagem da Mestrada-Prafissianalizante pelas ensinamentas que passibilitaram além desse estuda a mew crescimenta pessaal,

Aa Departamenta de Enfermagem da Pás-Cyraduaçãa de Enfermagem da UNESP pelas explanaçães e esclarecimentas de dívidas,

A prafessara $\mathscr{D r}_{r}{ }^{a}$ Maria Cristina Parada, coardenadara da Pragrama de Pás-graduaçãa de Enfermagem da UNESP par acreditar em mew patencial e dar a "start" dessa trajetária,

Aa prafessar Dr Carlas Padavani pelas arientaçães referentes à análise estatística e pelas palauras sinceras e significativas para a crescimenta desse estuda e da mew interiar,

Aa prafessar Tase Celsa Vieira pelas carreçães e arientaçães,

À enfermeira Ana Caralina, que farnecew sulsídias para a inícia deste estuda,

A tadas as calabaradares da UNESP-Batucatu que, de alguma maneira, puderam participar na realizaçãa deste sanha, cuja ajuda aferecida fai para mim de grande apreça,

Aa prafessar Dr Emília Carlas Curcelli pela cancardância na realizaçãa deste estuda na mew ambiente de trabalha, a "minha casinha": a Unidade de Internaçãa Pediátrica da Maspital Estadual de Bawrw, 
$\mathscr{A}$ gerente de enfermagem da Maspital Estadual de Baurw, Maria Valéria Pereira, pela autarizaçãa para cursar a Mestrada,

As supervisaras de enfermagem Libele Manteira Pecara e Karina Delicata pela likeraçãa para assistir às aulas, receber as arientaçães e pela apaia aferecida,

A micrabialagista da labaratária de Análises Clínicas da Haspital Estadual de Baum, Gislaine Aparecida Querina pela atençãa dispensada e dispasiçãa para me arientar,

Aas tadas as calabaradares da labaratária de Análises Clínicas da Maspital Estadual de Bauru, em especial à Regiane, Fátima, Telma e Marina pela paciência e dispasiçãa para me auxiliar durante a pesquisa, literalmente "peganda em minha mãa",

As minhas amigas, enfermeira Ana Paula Ribeira Razera e enfermeira Claudia R. Matiale Nunes pelas canversas, pelas mamentas de tristezas (que faram pancas) e pelas alegrais e risadas (que faram muitas) que pudemas ter durante a nassa percursa. Tenha certeza de que seria muita difícil sem vacês,

A equipe de enfermagem, aficiais e calabaradares da Unidade de Internaçãa Pediátrica da Maspital Estadual de Bauru pela apaia em minha trajetária prafissianal.

A tadas aqueles que, direta au indiretamente, faram impartantes e nãa tenham sida citadas.

As crianças que estãa au já passaram pela Unidade de Internaçãa Pediátrica da Maspital Estadual de Baurn pela simples fata de existirem e que me fazem querer adquirir mais canhecimentas para que ew passa cada vez mais ajudá-las. 
Epigrafe

“ canhecimenta nãa está nas liveras à espera que alguém wenha aprendê-la; a canhecimenta é praduzida em respastas às perguntas;

tada nava canhecimenta resulta de novas perguntas, muitas wezes navas perguntas sabre welhas respastas..."

(Pastman, 1969) 


\section{SUMÁRIO}

Lista de Quadros ........................................................................ 13

Lista de Figuras .................................................................................... 14

Lista de Fluxograma ............................................................................. 15

Lista de Tabelas ................................................................................ 16

Lista de Anexos ................................................................................ 18

Lista de Apêndices ................................................................................ 19

RESUMO ...................................................................................... 20

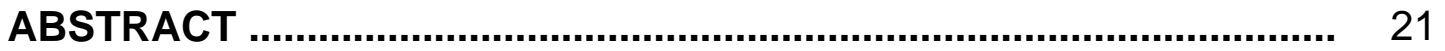

1. INTRODUÇÃO .................................................................................... 22

2. OBJETIVOS ............................................................................... 52

2.1. Objetivo Geral ............................................................. 53

2.2. Objetivos Específicos....................................................... 53

3. CASUÍSTICA E MÉTODOS .......................................................... 54

3.1. Referencial metodológico ................................................. 55

3.2. Casuística do estudo ......................................................... 56

3.3. Métodos ............................................................................ 57

3.3.1. Local do estudo ..................................................... 57

3.3.2. Unidade de internação pediátrica ................................. 58

3.3.3. Equipe de saúde da unidade de internação pediátrica ...... 58

3.3.4. Rotinas da unidade de internação pediátrica .................... 58

3.3.5. Controle de infecções da unidade de internação pediátrica. 59

3.3.6. Brinquedoteca ....................................................... 60

3.4. Aspectos éticos ......................................................... 61

3.5. Descrições do brinquedo ................................................ 61

3.6. Descrições dos produtos de higiene utilizados ........................ 62

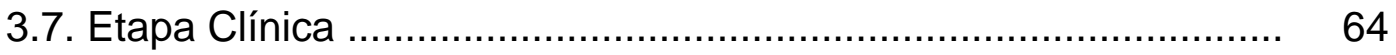

3.7.1. Amostragem ................................................... 64

3.7.2. Coleta das amostras das mãos ..................................... 65

3.7.3. Processo de observação e coleta das amostras dos 65 brinquedos .................................................................. 65

3.8. Etapa laboratorial ............................................................... 69 
3.8.1. Semeadura das amostras ...................................... 69

3.8.2. Análise das placas de Petri semeadas .......................... 70

3.8.3. Teste de sensibilidade dos produtos de higienização ........ 70

3.8.4. Variáveis do estudo ............................................. 72

3.8.4.1. Variável dependente e variáveis complementares . 72

3.8.4.2. Variáveis da análise bacteriana ........................ 77

4. RESULTADOS .......................................................................... 79

5. DISCUSSÕES.............................................................................. 111

6. CONCLUSÕES .......................................................................... 122

7. CONSIDERAÇÕES FINAIS ........................................................... 124

8. REFERÊNCIAS .................................................................... 128

9. ANEXOS ..................................................................................... 142

10. APÊNDICES ......................................................................... 145 


\section{LISTA DE QUADRO}

Quadro 1- Descrição dos produtos de higiene de acordo com sua atividade e mecanismos de ação 


\section{LISTA DE FIGURA}

Figura 1- Acomodação dos brinquedos na caixa de plástico............. 


\section{LISTA DE FLUXOGRAMA}

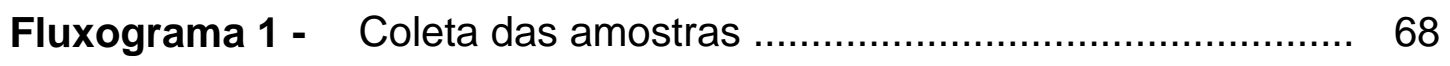




\section{LISTA DE TABELAS}

Tabela 1- Distribuição de frequência e percentual em relação à presença de bactérias nas mãos das crianças em idades pré-escolares e escolares. Bauru, 2009.

80

Tabela 2- Distribuição de frequência e percentual em relação à presença de bactérias nas mãos das crianças e sexo. Bauru, 2009.

Tabela 3- Descrição de frequência e percentual em relação às bactérias isoladas da mão direita e esquerda do préescolar e escolar. Bauru, 2009.

Tabela 4- Distribuição da frequência e percentual em relação à presença e ausência de bactérias encontradas nas amostras dos brinquedos no momento antes da brincadeira e imediatamente após a brincadeira. Bauru, 2009.

Tabela 5- $\quad$ Distribuição de frequência e percentual em relação à presença de bactérias encontradas nas amostras dos brinquedos no momento antes da brincadeira e depois da higienização do brinquedo. Bauru, 2009......

Tabela 6- Distribuição de frequência e percentual em relação à presença de bactérias encontradas nas amostras dos brinquedos no momento imediato após a brincadeira e depois da higienização do brinquedo. Bauru, 2009...

Tabela 7- Distribuição de frequência e percentual em relação à presença e ausência de bactérias no momento antes da brincadeira, imediato após a brincadeira e depois da higienização do brinquedo. Bauru, 2009.

Tabela 8- Descrição de frequências e percentuais de bactérias isoladas nas amostras dos brinquedos no momento antes da brincadeira, imediato após a brincadeira e depois da higienização do brinquedo. Bauru, 2009......

Tabela 9- Descrição das bactérias isoladas nas amostras das mãos e dos brinquedos das crianças em idade préescolar. Bauru, 2009. 
Tabela 10- Descrição dos antibiogramas das bactérias isoladas nas mãos do pré-escolar e nos momentos de coleta de swab no brinquedo. Bauru, 2009

Tabela 11- Descrição das bactérias isoladas nas amostras das mãos e dos brinquedos das crianças em idade escolar. Bauru, 2009

Tabela 12- Descrição dos antibiogramas das bactérias isoladas nas mãos do escolar e nos momentos de coleta de swab no brinquedo. Bauru, 2009.

Tabela 13- Descrição do teste de sensibilidade "in vitro" dos produtos de higiene relacionados com as bactérias isoladas e antibiograma nas amostras do pré-escolar. Bauru, 2009.

Tabela 14- Descrição do teste de sensibilidade "in vitro" dos produtos de higiene relacionados com as bactérias isoladas e antibiograma nas amostras do escolar. Bauru, 2009.

Tabela 15- Descrição da sensibilidade "in vitro" das bactérias isoladas frente aos produtos de higiene. Bauru, 2009. 


\section{LISTA DE ANEXOS}

Anexo 1 - Formulário A: Variável Dependente e Variáveis Complementares …...................................................... 143

Anexo 2 - Formulário B: Variáveis da análise bacteriana - Mãos e Brinquedos. 


\section{LISTA DE APÊNDICES}

Apêndice 1 - $\quad$ Termo de Consentimento Livre e Esclarecido.............. 146

Apêndice 2 - Parecer de concordância do Comitê Científico do Hospital Estadual de Bauru................................... 146

Apêndice 3 - Parecer de concordância do Comitê Científico do Hospital Estadual de Bauru.................................... 148

Apêndice 4 - Parecer de aprovação do Comitê de ética da Faculdade de Medicina de Botucatu.......................... 148

Apêndice 5 - Justificativa de alteração no título do projeto de pesquisa................................................................... 


\section{RESUMO}

Almeida MCC. Descrição bacteriológica de brinquedo utilizado em unidade de internação pediátrica. [dissertação]. Botucatu: Faculdade de Medicina, UNESP; 2009.

A hospitalização infantil acarreta fatores estressantes para a criança e sua família. É uma situação que pode trazer traumas emocionais à criança, exigindo dos profissionais da área da saúde além de tratamento terapêutico, o carinho e a atenção. Esses cuidados podem ser alcançados através do brinquedo, que proporciona à criança restabelecimento físico e emocional, contribuindo para sua recuperação. Todavia, há fatores que contribuem para que o uso do brinquedo se torne objeto de atenção especial quando se pensa em compartilhá-los e na falta de práticas de higiene para os mesmos em unidade de internação pediátrica, considerando que o brinquedo pode ser um veículo na transmissão de microrganismos. O objetivo deste estudo foi: descrever as condições bacteriológicas do brinquedo de plástico utilizados na unidade de internação pediátrica do Hospital Estadual Bauru (HEB). Utilizou-se swabs estéreis para a coleta das amostras das mãos e do brinquedo. A amostragem foi realizada utilizando swab estéril em três momentos: no primeiro momento realizou-se a coleta de swab das mãos das crianças e do brinquedo antes de iniciar a brincadeira, no segundo momento coletou-se a amostra imediatamente após a brincadeira e no terceiro momento houve a coleta de swab no brinquedo após o processo de higienização com álcool 70\%. Após as coletas, as amostras foram encaminhadas para o laboratório de Análises Clínicas do HEB onde foi realizada a semeadura das amostras em meios de cultura Ágar MacConkey e Manitol. Após 24 horas, observava-se a presença ou não de crescimento bacteriano. Quando havia crescimento bacteriano, seguia-se para a identificação do achado e, quando não havia crescimento bacteriano, mantinha-se a amostra na estufa por mais 24 horas para determiná-la como presente ou ausente de crescimento bacteriano. Seguidamente realizou-se o antibiograma e o teste de sensibilidade "in vitro" frente a produtos de higiene hospitalar por meio do método de difusão em Gel de Ágar. Os resultados obtidos mostraram que há, na maioria dos achados, crescimento bacteriano nas mãos das crianças e no brinquedo imediatamente após a brincadeira e até mesmo após a higiene do brinquedo com álcool 70\%. As bactérias isoladas foram: Stafilococcus coagulase negativa, Stafilococcus aureus, Pseudomonas aeruginosa e Acinetobacter. Apenas algumas amostras com Stafilococcus coagulase negativa apresentaram resistência ao antibiótico. Frente às bactérias isoladas "in vitro", os produtos de higiene que apresentaram sensibilidade foram: as clorexidinas - alcoólica $2 \%$ e degermante $2 \%$ - seguido do álcool $70 \%$ e do hipoclorito $1 \%$. A água e sabão apresentaram resistência. Concluí-se que o brinquedo utilizado em unidade de internação pediátrica pode ser veículo na transmissão de microrganismos. Recomenda-se rotinas para a higienização dos brinquedos em unidades de internações e a utilização da clorexidine alcoólica $2 \%$ para a higienização dos brinquedos de plástico compartilhados em brincadeiras.

Palavras-chave: brinquedo, higiene, infecção hospitalar. 


\begin{abstract}
Almeida MCC. Bacteriological description of toys used at a Pediatric Hospitalization Unit. [thesis]. Botucatu: Faculdade de Medicina, UNESP; 2009.

Children's hospitalization leads to stressful factors for patients and their relatives. It is a situation that can cause emotional trauma in children, thus requiring kindness and attention from health care professionals, in addition to therapeutic care. Such care can be achieved by means of toys, which help children recover physical and emotional wellness, thus contributing to their health recovery. Nevertheless, there are factors that contribute for toy use to become an object of attention when considering the fact that toys will be shared and the lack of toy hygiene practices at pediatric hospitalization units, since they may be a vehicle for microorganism transmission. The objective of this study was: to describe the bacteriological conditions of plastic toys used at the hospitalization unit of Bauru State Hospital (BSH). Sterile swabs were used to collect samples from hands and toys. Sampling was performed by using sterile swabs at three different moments: at the first moment, swab collection was performed from children's hand and from toys before playing began; at the second moment, a sample was collected immediately after playing; and, at the third moment, swab collection from the toy took place after hygienization using $79 \%$ alcohol. Following collection, the samples were sent to the Laboratory of Clinical Analysis of $\mathrm{BSH}$, where they were seeded in Agar MacConkey and Manitol culture media. The presence or not of bacterial growth was observed after 24 hours. Whenever bacterial growth occurred, the findings were identified, and when no growth was observed, the sample was kept in a stove for another 24 hours in order to determine it as present or absent of bacterial growth. Next, an antibiogram and in-vivo sensitivity tests for hospital cleaning products were performed by the Agar-Gel diffusion method. Results showed that, in most findings, bacterial growth occurred on the children's hands and on the toys immediately after playing and even after the toy's hygienization with $70 \%$ alcohol. The isolated bacteria were: coagulase-negative Staphylococcus, Staphylococcus aureus, Pseudomonas aeruginosa and Acinetobacter. Some small samples with coagulase-negative Staphylococcus showed antibiotic resistance. In face of the bacteria isolated in vivo, the hygiene products showing sensitivity were: chlorhexidines - $2 \%$ alcoholic and $2 \%$ degermant, followed by $70 \%$ alcohol and $1 \%$ hypochlorite. Water and soap showed resistance. It was concluded that the toys used in pediatric hospitalization units can be vehicles of microorganism transmission. Routines for toy hygienization in hospitalization units and the use of $2 \%$ alcohol chlorhexidine for hygienization of plastic toys shared during playing are recommended.
\end{abstract}

Key words: toy, hygiene, nosocomial infection. 
1. Intraduçãa 


\section{INTRODUÇÃO}

A história do surgimento e evolução dos hospitais tem início com o advento do Cristianismo, com as Santas Casas de Misericórdia e as Sociedades de Beneficência ${ }^{(1,2)}$.

No final do século XVIII, na Europa monarquista, ocorreu a construção de alguns hospitais gerais cujas condições higiênicas e sanitárias eram precárias. Iniciou-se então a ocorrência da alta mortalidade hospitalar devido às grandes epidemias, o que levou alguns profissionais a relacionar determinadas doenças com o aglomerado de pacientes. Ao fim do século XIX médicos percebem o aparente contágio das doenças e começam a delinear medidas para minimizar essa disseminação ${ }^{(3)}$.

O aumento crescente da população obrigou os governos a organizar unidades que pudessem acomodar os enfermos e facilitar a assistência que se pretendia prestar a eles. Na década de 1960, o crescimento brasileiro, econômico, da indústria e da urbanização, leva ao aumento pela procura por assistência à saúde iniciando a construção de hospitais ${ }^{(1,4)}$.

Já no século $X X$, a história foi se transformando devido ao avanço dos conhecimentos sobre a natureza e as doenças, com novos métodos diagnósticos e terapêuticos, com o crescimento da indústria e o desenvolvimento de aparelhos sofisticados, fazendo com que os hospitais se organizassem administrativa e economicamente e devido também ao 
esclarecimento da população, principalmente acerca dos seus direitos ao acesso à saúde ${ }^{(1)}$.

Nos últimos anos, grande parte da atenção à saúde ocorre em hospitais modernos, complexos e grandes centros que possuem amplos campos de serviços como diagnósticos e prevenção ${ }^{(2)}$. Hoje a situação hospitalar divide a sociedade em dois lados, que se conflitam: o dos que têm acesso aos meios de assistência médica mais avançada, as comunidades ricas e poderosas, que é a minoria, e os que se situam fora desses limites, a maioria, despossuída e frequentemente aculturada ${ }^{(1)}$.

A hospitalização infantil também aumentou nos últimos anos elevando a taxa de internações hospitalares a números significativos. Todos os anos mais de um milhão de crianças em nosso país passam pelo processo de hospitalização $^{(5)}$.

A experiência da hospitalização na infância é potencialmente traumática, pois pode acarretar o surgimento de sentimentos diversos como medo e ansiedade diante dessa situação ameaçadora, podendo comprometer seu processo de desenvolvimento e interação social ${ }^{(6)}$.

Os primeiros estudos, aproximadamente em 1950, avaliavam as consequências da hospitalização no desenvolvimento da criança e visavam identificar as reações negativas enfatizando as depressões, a apatia, o pânico e as birras manifestadas durante a internação. Tratava-se de estudos que se fundamentavam na valorização vínculo mãe-filho e que analisavam a separação extrema e a privação ${ }^{(2,6)}$. 
Num segundo período, em meados da década de 80, o estudo se voltou para o outro lado da hospitalização, tentando compreender processos de proteção alegando que já não se pode afirmar que uma única internação possa resultar em consequências negativas no desenvolvimento da criança. Porém, apesar de toda a evolução descrita, a hospitalização infantil ainda não é agradável; encontram-se grandes dificuldades desde a acomodação dos pais, interrupção da rotina diária da criança e a presença de equipamentos são condições que dificilmente serão eliminadas com rapidez ${ }^{(2,7)}$.

A situação de hospitalização surgiu juntamente com a institucionalização, onde as crianças eram separadas do ambiente familiar, permitindo apenas visitas rápidas de seus pais, que eram vistas como problemáticas e desaprovadas. O tempo de internação era prolongado e as crianças permaneciam nas camas sem estímulo para que saíssem e os processos de analgesia e sedação eram pouco desenvolvidos e praticados ${ }^{(2)}$.

O processo de internação hospitalar da criança sofreu grandes mudanças na maioria dos países, e ora vem se delineando com ações como a criação de especializações para a pediatria, maior preocupação com analgesia e sedação pediátrica, novas formas de tratamento e especificidade infantil, estímulo ao menor tempo de internação, adequação do ambiente para facilitar sua estada, presença de brinquedos e educadores e, sobretudo a condição da possibilidade de um acompanhante, contribuíram para essa nova fase da experiência da hospitalização ${ }^{(2,6,8)}$. 
A hospitalização de uma criança é um desafio a ser enfrentado por todos os que estão envolvidos nesse processo. É uma situação considerada determinadora de estresse, que pode fazer com que a criança fique emocionalmente traumatizada em maior grau do que está fisicamente doente. É perceptível a mudança de comportamento da criança doente; ela não tem ânimo para brincar e torna-se mais quieta que o comum, fazendo com que nesse momento ocorra não apenas o cuidado técnico, mas também o carinho e a atenção são fatores de extrema importância para a recuperação da saúde da criança $^{(9-11)}$.

Quando ocorre a internação hospitalar, a criança sai de sua rotina podendo apresentar distúrbios psicológicos, como ansiedade, alterações sensórias como: turvação da visão, alucinações, ilusões e desorientação ocorridas pelo medo do desconhecido ${ }^{(12)}$. A criança traz consigo, além do corpo doente, todas as experiências vivenciadas com sua história familiar: os amigos, a escola e as atividades cotidianas como o brincar. Diante dessa situação, a criança precisa ser acolhida, compreendida e respeitada e o profissional de saúde deve ser capaz de compreender a situação de fragilidade da criança, pois ela precisa ver nele o indivíduo que a entenda e respeite ${ }^{(8,11)}$.

Encontramos algumas práticas de atenção à criança hospitalizada onde os profissionais utilizam o brincar como estratégia de intervenção no campo da saúde da criança. Algumas ações apresentam-se apenas como recreação e outras utilizam o brincar como abordagem terapêutica. Estudo refere que o brincar exige muito conhecimento teórico tanto quanto outras técnicas de cuidados e procedimentos ${ }^{(6)}$. Florence Nightingale já preconizava para a 
criança cuidados de higiene física, alimentar e meio ambiente, bem como a recreação e ar puro ${ }^{(8)}$.

A palavra brincar deriva etimologicamente do latim brinco, que significa estabelecer laços, ligar-se. É algo essencial na vida da criança que alicerça seu desenvolvimento emocional, psicológico e social ${ }^{(13,14)}$. Além de proporcionar relaxamento e diversão, traz também encorajamento para a interação com outras crianças para torná-la mais segura ${ }^{(14)}$.

Sabe-se que o brincar é uma das características que distinguem o homem dos outros seres, relacionando a atitude como parte da constituição humana ${ }^{(15)}$. Já comprovaram a importância do brincar para o desenvolvimento sensório-motor e intelectual da criança, assim como sua importância no processo de socialização, no desenvolvimento e aperfeiçoamento da criatividade e autoconsciência, além da importância da formulação dos valores morais ${ }^{(11,16,17)}$. O modo como a criança brinca expressa como ela é e como ela está (10).

O desenvolvimento infantil está vinculado ao brincar, uma vez que este se apresenta como a linguagem própria da criança, possibilitando o acesso às informações e a assimilação do que ocorre ao seu redor. O brincar está caracterizado como linguagem, como forma de expressão e é uma maneira de a criança receber o mundo ${ }^{(16)}$.

A literatura traz que o desenvolvimento infantil se encontra vinculado ao lúdico, uma vez que o lúdico representa o brincar e este por sua vez representa a linguagem própria da criança. Considera que atividade lúdica é a atividade 
que motiva intrinsicamente o sujeito, pois a finalidade não está no seu feito utilitário ou resultado externo, mas está nas variadas vivências da realidade ${ }^{(11)}$.

Em qualquer ambiente ou situação, o brinquedo é o companheiro inseparável da criança, mas quando ocorre a hospitalização desta, num local que não tem uma estrutura física adequada para a criança, o resultado poderá gerar danos que marcarão sua vida e seu desenvolvimento ${ }^{(18)}$. Sendo o brincar uma linguagem universal e que remete ao prazer e à alegria, ele acaba se estendendo a toda instituição que atende a crianças ${ }^{(19)}$.

Como uma estratégia de enfrentamento de tal situação, surge o brincar e os brinquedos dentro das instituições de saúde, com a intenção de minimizar os efeitos da hospitalização, tanto para as crianças quanto para os profissionais da área da saúde ${ }^{(9)}$. Contextualizando a função dos brinquedos, dos jogos e das brincadeiras para a criança hospitalizada, observa-se que esses favorecem e asseguram a continuidade do seu desenvolvimento e ajudam a encontrar um sentido de normalidade em um ambiente com histórico amedrontador - o hospital ${ }^{(13)}$.

Com isso, a atividade lúdica, ou seja, brincar no hospital, deve ser vista como instrumento terapêutico a serviço da intervenção oferecida à criança, apresentando efeitos além da recreação, uma vez que essa técnica consegue amenizar o sofrimento da hospitalização ${ }^{(20)}$. Estudos demonstram que a tensão e o estresse da criança aumentam quando o hospital não oferece recursos para que ela desenvolva essa atividade de brincar, o que a leva a recorrer para um comportamento agressivo, introspectivo de medo e sofrimento ${ }^{(13,21)}$. 
Houve uma maior compreensão das necessidades emocionais da criança durante a hospitalização o que estimulou os membros da equipe de saúde a criar métodos de assistência que tornem possível um ajustamento construtivo à doença e à hospitalização ao invés de tornar a internação em um ato resultante de trauma. A equipe de saúde por meio desse ato pode diminuir os efeitos estressantes e prevenir tais traumas utilizando-se da humanização da assistência prestada à criança ${ }^{(12)}$.

Está garantida por lei, por meio da resolução $\mathrm{n}^{0} .41$ do Ministério da Justiça e do CONANDA - Conselho Nacional dos Direitos da Criança e do Adolescente de Outubro de 1995 que "toda criança e adolescente hospitalizado tem direito de desfrutar de alguma forma de recreação, programas de educação para a saúde, acompanhamento de currículo escolar durante a permanência hospitalar". Objetivando o brincar espontâneo como elemento para o desenvolvimento da criança, sua criatividade, aprendizagem e socialização é que surgem as brinquedotecas, inicialmente pelos estudos da psicologia $^{(15)}$.

Nos últimos anos, observam-se mudanças no ambiente hospitalar, nos padrões do que é oferecido às crianças em relação ao ato de brincar, destacando-se a implantação de brinquedotecas em hospitais públicos e privados ${ }^{(13)}$. E mais uma conquista para as crianças em seu tratamento hospitalar, foi a Lei Federal 11.104, de 21 de março de 2005, que dispõe a obrigatoriedade das brinquedotecas nas unidades que oferecem atendimento pediátrico em regime de internação ${ }^{(18,22,23)}$. 
Esta lei surgiu a partir de movimentos de humanização em hospitais e significa a inclusão do brinquedo no ambiente hospitalar, como parte da assistência e da terapêutica aplicada pela psicologia às crianças e aos adolescentes hospitalizados ${ }^{(22)}$.

Nas brinquedotecas hospitalares, percebe-se a necessidade de reinventar a realidade; estes espaços, além da importância acolhedora, também oportunizam situações de socialização e desenvolvimento de algumas habilidades dos pacientes como a atenção, a concentração, a afetividade e a cognição ${ }^{(22)}$.

O brinquedo tem valor terapêutico para as crianças hospitalizadas, pois influencia no restabelecimento físico e emocional e pode tornar esse processo menos traumatizante e mais alegre, resultando em melhores condições para a recuperação da criança ${ }^{(8)}$. Oferece a contribuição efetiva da comunicação entre o enfermeiro e a criança, no sentido de amenizar os seus medos e do seu acompanhante/família, permitindo a dramatização desses papéis ou dos conflitos $^{(10)}$.

A grande vantagem encontrada nas crianças é a versatilidade e a criatividade que elas têm em transformar instrumentos hospitalares em brinquedos, como quando a balança, o fluxômetro, o suporte de soro, a tala e mais, são vistos com outros olhos e passam de objeto de desconforto ou dor para objeto de prazer e distração, como visto em estudo, conforme trecho abaixo ${ }^{(8)}$ : 
“... C. brinca com uma boneca que parece estar doente, pois tem eletrodos; as crianças têm várias seringas nas proximidades. A brincadeira gira em torno de cuidados, elas pouco conversam, mas agem muito, aplicam injeções, mudam os eletrodos quando soa o bip, também simulados por elas..."

O brincar e os brinquedos terapêuticos (BT) surgem como forma de colaborar com o tratamento da criança. São vistos como elementos que propiciam o resgate de um contexto familiar à criança e à sua própria condição de criança. São facilitadores para a interação entre os profissionais de saúde, crianças e seus acompanhantes ${ }^{(19)}$.

Permitem estabelecer um relacionamento com a criança de uma maneira segura, e que permita a realização de procedimentos e a obtenção de informações relativas a aspectos de sua vida pessoal a fim de estabelecer metas para a assistência de enfermagem como um canal de comunicação e aceitação que permite preparar a criança e conseguir modificações de comportamento frente à hospitalização. Assim a enfermagem pode utilizar-se da técnica do brinquedo terapêutico como um todo ${ }^{(24,25)}$.

O BT tem como meta dar ao enfermeiro a compreensão dos sentimentos e necessidades da criança, através da utilização do brinquedo. Pode ser usado para qualquer criança, hospitalizada ou não, e a atividade pode ser realizada em uma sala de brinquedos, no quarto da criança ou qualquer ambiente conveniente ${ }^{(7,10)}$. Ele baseia-se na função catártica do brinquedo e tem sido utilizado pelos enfermeiros não só como um meio de alívio para as tensões impostas à criança, mas também como uma possibilidade de comunicação pela qual podem dar explicação e receber informações da criança, do que as situações significam para ela ${ }^{(9)}$. 
Para as atividades com BT, além dos materiais específicos, é essencial que durante a sessão ela perceba a presença de um adulto que aceite e encoraje a expressão dos seus sentimentos. De acordo com estudo ${ }^{(26), ~ s u a ~}$ finalidade e intenção, o BT pode ser classificado em três tipos como:

1- brinquedo terapêutico dramático: sua finalidade é permitir que a criança exteriorize suas experiências que não consegue verbalizar, aliviando sua tensão, medo e expressando suas necessidades,

2- brinquedo terapêutico instrucional: com a finalidade de preparar e informar a criança sobre os procedimentos terapêuticos que ela será submetida, para situá-la e facilitar sua compreensão,

3- brinquedo terapêutico capacitador de funções fisiológicas: usado para capacitar a criança para o autocuidado, de acordo com seu desenvolvimento e condições físicas.

Proporciona à criança hospitalizada a oportunidade de reorganizar a sua vida, seus sentimentos e diminuir a ansiedade, podendo também ser utilizado para ajudá-la a reconhecer seus sentimentos, assimilar novas situações, compreender o que se passa no hospital e esclarecer conceitos errôneos ${ }^{(27)}$.

Os objetivos mais marcantes das brinquedotecas hospitalares são voltados para diminuir a ansiedade e os traumas relacionados à hospitalização, fortalecer a estrutura familiar, recuperar ou fortalecer a autoimagem, autoconfiança e autoestima, estabelecer relações amigáveis e prazerosas que procuram minimizar a doença e o tratamento ${ }^{(18)}$. 
O Conselho Federal de Enfermagem (COFEN), percebendo o envolvimento e a responsabilidade do enfermeiro relacionado ao uso dos brinquedos, lançou a resolução COFEN n 295/2004 - Artigo 1 - "compete ao enfermeiro que atua na área pediátrica; enquanto integrante da equipe multiprofissional de saúde, a utilização da técnica do Brinquedo/Brinquedo terapêutico, na assistência à criança e a família hospitalizada" (28).

Nessa estratégia para a busca da humanização no atendimento à criança hospitalizada, desde a década de 90, volta-se à ideia para a participação familiar e dos acompanhantes das crianças como participantes dos procedimentos hospitalares, recebendo informações continuamente e permanecendo em tempo integral ao lado da criança ${ }^{(29,30)}$.

É imprescindível que a equipe que cuida da criança compreenda a necessidade do brincar como uma necessidade básica, valorizando assim o brinquedo tanto quanto a higiene, a medicação, a alimentação e os outros cuidados não considerando a atitude do brincar apenas como uma atividade de recreação que se alguém tiver tempo realizará com a criança ${ }^{(12,9)}$.

O hospital que faz uso desse recurso tem que elaborar rotinas para a limpeza e a desinfecção desses brinquedos e medidas profiláticas, pensando em proteção para as crianças e até mesmo para os profissionais trabalhadores, elaborar medidas profiláticas considerando a possível transmissão de patógenos pelos brinquedos que podem distribuir microrganismos para todos os que deles se utilizarem. As crianças podem estar expostas a infecções cruzadas porque elas compartilham os brinquedos presentes no ambiente hospitalar onde estão internadas ${ }^{(31,32)}$. 
Há a importância da divulgação e da implementação das medidas de segurança específicas e higiene dos brinquedos em ambiente hospitalar, incorporando a atividade de brincar, pela equipe que cuida, como filosofia de seu cuidado ${ }^{(13)}$.

O tipo de brinquedo escolhido ou fornecido à criança pode ajudar em seu desenvolvimento, mas sabendo-se que num hospital a interação entre crianças é frequente principalmente em áreas comuns como a brinquedoteca, há a preocupação do uso do brinquedo pelo risco de contaminação com secreções, tornando-os veículos de transmissão de patógenos ${ }^{(32)}$.

$\mathrm{Na}$ escolha dos brinquedos, devem ser considerados alguns aspectos como os riscos de transmissão de microrganismos para os pacientes, a natureza do material do qual é confeccionado o brinquedo e se este é passível de limpeza e desinfecção ${ }^{(33)}$.

No Brasil, existe a Associação Brasileira de Normas Técnicas (ABNT) que possui a norma técnica $n^{\circ} 11786$ que cuida exclusivamente da segurança dos brinquedos fabricados e comercializados no país. A ABNT realiza testes e simulações relativos a situações comuns e extremas no dia a dia, como puxar, bater, derrubar, pisar e atirar o brinquedo. Após avaliação, o Instituto Brasileiro de Qualificação e Certificação realiza um programa de certificação de qualidade do produto e emprega um selo de garantia para os brinquedos testados ${ }^{(13)}$.

Estudos ${ }^{(13,34,35)}$ descrevem que há práticas de segurança com brinquedos divididos em quatro princípios, como: 
1 - seleção- os brinquedos devem estimular a criatividade da criança e proporcionar distração. Deve-se considerar a idade, as habilidades e as capacidades. A qualidade do brinquedo precisa ser avaliada e devem-se respeitar as recomendações do fabricante sobre segurança. De modo geral, os brinquedos devem ser leves, atóxicos, sem produção de ruídos altos e estridentes, sem pontas ou bordas afiadas, sem correntes, tiras e cordas com mais de $15 \mathrm{~cm}$. Na composição do brinquedo, devem-se considerar as superfícies e as dimensões, de modo que sejam de fácil higiene.

2 - supervisão- as crianças devem ser supervisionadas de perto durante suas brincadeiras;

3 - manutenção- inspecionar os brinquedos com regularidade, os novos e os antigos, realizando reparos e trocas necessárias;

4 - armazenamento- os brinquedos devem ficar em local seguro de acordo com a faixa etária, isenta de dispositivos de travamento que possam ferir ou cair sobre a criança.

Devem existir rotinas estabelecidas junto à equipe, quando se referem aos produtos utilizados na higienização e treinamento de responsáveis por esta rotina e do setor de compras, dando destaque à composição e detalhes para a compra dos brinquedos ${ }^{(13)}$.

Os artigos de uso hospitalar possuem classificação e segundo Spaulding podem ser ${ }^{(33)}$ : 
a) artigos críticos: são os que penetram através da pele e mucosas atingindo os tecidos subepiteliais e sistema vascular, que devem ser esterilizados;

b) artigos semicríticos: são os que entram em contato com mucosa íntegra do paciente, são artigos que requerem desinfecção (destruição de microrganismos na forma vegetativa, com exceção dos esporos);

c) artigos não críticos: são os que entram em contato com a pele íntegra do paciente; a maioria requer apenas limpeza (remoção mecânica da sujidade e conseqüente redução da população microbiana).

Essa classificação favorece a escolha do processo de limpeza e desinfecção dos brinquedos que podem ser considerados artigos semicríticos e não críticos ${ }^{(33)}$.

De acordo com o Consumer Product Safety Commission (CPSC), deve haver higiene dos brinquedos sempre que possível e principalmente quando tiver contato com saliva ou outras secreções corporais sendo higienizados com uma solução de hipoclorito $1 \%{ }^{(13,36)}$.

Outros métodos recomendados para a higiene dos brinquedos em ambiente hospitalar são: limpeza com detergente neutro (manual), detergente enzimático (máquina de lavar), desinfecção por termo desinfecção ou solução germicida (por imersão ou fricção). A secagem e armazemanento adequado também têm importante papel no processo de higienização ${ }^{(35)}$.

Todos esses cuidados são relacionados com a Infecção Hospitalar (IH) que representa um importante problema de saúde pública, tanto no Brasil quanto no mundo e constitui risco à saúde dos usuários dos hospitais que se submetem a procedimentos terapêuticos ou de diagnóstico ${ }^{(4,37)}$. 
Na metade do século passado, apesar de não se ter conhecimentos de microbiologia, foi-se percebendo a associação entre hospitalização e infecção, de onde surge o termo "hospitalismo" para as infecções adquiridas no hospital ${ }^{(38)}$.

A situação de insalubridade dos hospitais reconhecidas no século XVIII transforma-se quando ocorre uma mudança na concepção de hospital, ao se retirar a ideia de local para aguardar a morte e torná-lo um local destinado à cura. Essa situação persiste ainda até o século XIX quando aparecem no cenário hospitalar à bacteriologia, por Pasteur e os conceitos de assepsia, por Lister. Nessa época, também a enfermagem assume as funções de prevenção e controle das contaminações por ambiente hospitalar, desde o desempenho de Florence Nightingale ${ }^{(38)}$.

As infecções hospitalares existem desde a idade média, mas seu reconhecimento como problema de saúde pública ocorreu apenas na década de $50^{(39)}$. No Brasil, alguns hospitais começaram a preocupar-se na década de 70 e iniciaram medidas como prevenção e controle ${ }^{(40)}$.

$\mathrm{Na}$ década de 80, o assunto passa a ser objeto de ações governamentais com publicações de portarias para regulamentar e normatizar serviços e medidas de prevenção e controle das infecções hospitalares ${ }^{(41,42)}$.

O Ministério da Saúde define então como Infecção Hospitalar (IH) "aquela adquirida após a admissão do paciente e que se manifeste durante a internação ou após a alta, quando puder ser relacionada com a internação ou procedimentos hospitalares", segundo a portaria n. 2.616, de 12 de maio de $1998^{(41)}$. 
Embora as principais causas de $\mathrm{IH}$ estejam relacionadas com o doente susceptível à infecção e com os métodos-diagnósticos e terapêuticos utilizados, não se pode deixar de considerar a parcela de responsabilidade relacionada aos padrões de assepsia e de higiene do ambiente hospitalar e seus utensílios ${ }^{(43)}$.

A participação da enfermeira Florence Nightingale na prevenção das infecções foi extremamanente fundamental, quando em 1854, ela e mais 38 enfermeiras foram designadas para o hospital de base de Scutari, em Constantinopla, hoje Istambul, ficando responsáveis por 1500 pacientes. Era o período da guerra entre a Rússia e as forças armadas da Inglaterra, França e Turquia e o hospital chegava a ter 3000 a 4000 feridos e doentes. O hospital não tinha nenhuma condição de higiene, não havia sanitários, os leitos e roupas de cama eram insuficientes, não havia bacia, sabão ou toalhas, as pessoas comiam com as mãos e a taxa de mortalidade era de $42 \%{ }^{(44)}$.

Foi com sua iniciativa que se desenvolveu um trabalho sistemático para a aquisição de um conhecimento diferente dos já buscadas pelos médicos no hospital reorganizado, onde os fundamentos se originavam das ações da Medicina Social, ou seja, permitir a manutenção do organismo em não adoecer ou de se recuperar. Essa percepção de mudar a doença para ação da restauração da saúde deu para a enfermagem uma dimensão original das suas ações como a de favorecer o processo de recuperação com o uso do ambiente, da limpeza e da dieta ${ }^{(4)}$. 
Ainda traz na literatura que Florence iniciou então a organização desse hospital instalando cozinhas, lavanderias, melhorando as condições sanitárias, abrindo janelas para a entrada do ar e da luz, fazendo rondas à noite para levar assistência e conforto aos doentes e feridos. Conseguiu então reduzir a mortalidade de $42,7 \%$ para 2,2\%. Após essa conquista, ela retorna a Londres, inaugura uma escola de enfermeiras e publicam trabalhos valorizando as condições ambientais como limpeza, iluminação natural, ventilação, odores, calor, ruídos, sistema de esgoto mais do que a estética. Reforça e comprova a necessidade de mudanças de condutas pensando na redução da transmissão de patógenos ${ }^{(44)}$.

É bom lembrar que a IH não é somente uma preocupação dos órgãos de saúde competentes, mas um problema de ordem social, ética e jurídica em face às implicações na vida dos usuários e o risco a que estes estão submetidos, trazendo repercussões penais, civis e éticas, as quais nascem em decorrência de atos falhos cometidos pelos profissionais e acabam gerando consequências danosas aos seus clientes. E além da responsabilidade dos profissionais envolvidos no atendimento aos usuários, há também a fiscalização da ANVISA (Agência Nacional de Saúde) e dos gestores das instituições, que exigem responsabilidade no atendimento, para não ocorrer descaso ou descuido ${ }^{(45)}$.

O pensamento voltado para as IH não é algo recente. Consta na história, que em 1843, Oliver Wendel Homes sugeriu que os médicos, inconscientemente, eram a maior causa de complicações infecciosas nas parturientes e nos recém-nascidos, decorrente das mãos não higienizadas. Em 
1846, uma notória preocupação surgiu no Hospital Geral de Viena, com Ignaz Semmelweis. O mesmo obrigou que todas as pessoas, antes de entrar nas salas de Clínica Obstétrica, lavassem as mãos com uma solução de ácido clórico até mesmo se fossem somente examinar as puérperas. Com essa atitude, ele reduziu significativamente os números de mortalidade materna, de 18,27 para 3,07\% dentro de dois meses. Essa foi à primeira evidência científica de que a lavagem das mãos pudesse transmitir alguma infecção ${ }^{(37)}$.

Sendo a lavagem das mãos um plano assistencial importante para a prevenção da transmissão de doenças infecciosas ${ }^{(46)}$, a equipe de saúde deve conhecer e utilizar adequadamente os princípios da técnica ${ }^{(47,48)}$.

As mãos dos próprios profissionais de saúde podem ser veículos importantes na transmissão de microrganismos dentro do hospital ${ }^{(46,49,50)}$. Tem-se como veículo a forma de transmissão indireta e qualquer objeto ou material inanimado que possa carrear algum microorganismo ${ }^{(17)}$.

Estudos mostraram que as infecções preveníveis, cerca de 30 a 50\% do total das infecções hospitalares, estão entre as quais são geradas por falhas nos cuidados ao paciente, como exemplos: o uso e a manutenção das sondas nas vias urinárias, cateterismo venoso, terapia respiratória, imperícias cirúrgicas e ausência do hábito das lavagens das mãos. A pele das mãos apresenta uma população de microrganismos que pode ser diferenciada em flora residente (normal) e flora transitória, sendo flora transitória aquela constituída por qualquer microorganismo depositado sobre a pele, sem, no entanto, colonizá-la como ocorre com os da flora residente ${ }^{(51,52)}$. 
Resultados obtidos da observação do comportamento dos profissionais de saúde com relação à lavagem das mãos, antes do cuidado com crianças portadoras do diagnóstico de diarreia aguda bacteriana, em uma Unidade de Internação Pediátrica e Pronto-Socorro de Pediatria mostraram que 66,6 \% dos docentes, $25 \%$ dos residentes, $30 \%$ dos enfermeiros e apenas $11,4 \%$ dos auxiliares de enfermagem lavavam suas mãos. Essa autora conclui que a maioria dos profissionais de saúde não demonstrou o hábito de lavar as mãos antes e após os cuidados com criança portadora de diarreia aguda bacteriana, particularmente os enfermeiros ${ }^{(49)}$.

Em 1863, a enfermeira Florence Nightingale descrevia os procedimentos relacionados aos pacientes e ao ambiente, com a finalidade de diminuir os riscos da infecção hospitalar; ela solicitava às enfermeiras que mantivessem um sistema de relatos dos óbitos para avaliar o serviço. Esta atitude é a primeira referência de Vigilância Epidemiológica, onde Florence trabalhou juntamente com seu colaborador William Farr, que fazia análises estatísticas dos dados coletados referentes aos relatórios ${ }^{(44)}$.

Nas décadas de 50 a 60, ainda que o termo infecção hospitalar não seja usado, escreve-se sobre infecção em setores, a resistência a antibióticos já é conhecida, assim como críticas à falta de critérios do seu uso, porém sem associação com infecção endógena. Na década de 70 , o crescimento da industrialização e a urbanização tiveram como consequência o aumento da assistência à saúde, com a expansão das indústrias farmacêuticas e de equipamentos hospitalares. A assistência médica e sua tecnologia aumentam sua forma de utilização sem controle adequado, tendo como resultado as 
infecções endógenas e as exógenas, reconhecendo a multicausalidade das IH, tanto relacionada ao ambiente e procedimentos, quanto à susceptibilidade individual e à evolução do modo clínico e sua incorporação de tecnologia ${ }^{(4)}$.

Estudo descreve que nessa época se percebe a necessidade de controlar e formar um processo de trabalho específico para o Controle de Infecção Hospitalar $(\mathrm{ClH})$, trazendo a idéia de organizar uma Comissão de Controle de Infecção Hospitalar $(\mathrm{CClH})$, para realizar essas atividades nas instituições de saúde, onde o enfermeiro é reconhecido como um dos agentes principais ${ }^{(27)}$. As atividades desenvolvidas pelos enfermeiros que compõem a CCIH são bastante distintas, pois eles devem exercer ações técnicas, burocráticas, de educação continuada e outras ${ }^{(53)}$.

No final desta década, a resistência dos microrganismos inicia a era antimicrobiana, devido ao aumento dos números do uso clínico destas drogas que geram uma resistência considerável dos genes, apesar de eles existirem na natureza e precederem ao uso clínico das drogas. Nesse período, algumas medidas precisaram ser adotadas para minimizar esse crescimento e a capacidade de mutação dos microrganismos, das quais se inicia a indicação fundamentada dos antibióticos, a vigilância e o isolamento dos pacientes com cepas multirresistentes, dando destaque para a eficácia do controle do Staphylococcus aureus resistentes à oxacilina ${ }^{(39)}$.

Na década de 80, a IH aumenta em quantidade e gravidade, juntamente com a péssima condição da assistência prestada, além da falta e desigualdade de acesso. Foi num cenário sociopolítico com aumento dos números de 
hospitais que as IH tiveram repercussão no Brasil, desencadeadas por denúncias da população atendida nesses hospitais, públicos e privados, pela divulgação na mídia sobre essa ação e pela forma de gerir os recursos financeiros não suficientes pela Previdência Social ${ }^{(39)}$.

As ações governamentais regularizam a CCIH para atender à demanda. Não se nega a estreita relação da $\mathrm{IH}$ com 0 modelo de assistência predominante e sua qualidade, mas a melhor qualificação dessa assistência, através da $\mathrm{CCIH}$, vem mais forte a partir da década de $90^{(27)}$.

A pesquisa nacional e o maior intercâmbio com centros internacionais favorecem o conhecimento de fontes de microrganismos, fontes e formas de infecção, permitindo discutir práticas e novas tecnologias e a enfermagem também contribui com pesquisas importantes nessa área e assunto ${ }^{(4)}$.

Em 1985, é publicado o "Manual de Controle de Infecção Hospitalar", com a finalidade de ser referência de consulta para o profissional envolvido no controle de IH, para a solução de problemas específicos e atuar como um guia de orientação na resolução da infecção hospitalar ${ }^{(42)}$.

A portaria n. 2.616, de 12 de maio de 1998, traz no Anexo I, que "para a adequada execução do Programa de Controle de Infecção Hospitalar (PCIH), os hospitais deverão constituir Comissão de Controle de Infecção Hospitalar $(\mathrm{CClH})$, órgão de assessoria à autoridade máxima da instituição e de execução das ações de controle de infecção hospitalar" $(39,41)$.

A literatura $^{(4)}$ traz ainda que a década de 90 vivenciou as tentativas de implementar o sistema de saúde vigente (SUS). Na prática, quando se diz 
sobre $\mathrm{CClH}$, apesar de toda mobilização dos profissionais e das ações governamentais específicas através das legislações, campanhas, cursos e treinamentos, a coordenadoria de CIH do Ministério da Saúde reconhece, em 1993, a pouca efetividade nos hospitais, estimando em apenas $10 \%$ a criação da $\mathrm{ClH}$.

Ainda existem desafios a serem superados em relação ao controle de infecção como os agentes infecciosos emergentes, a resistência microbiana, o incremento de métodos invasivos no diagnóstico e na terapêutica, as consequências das transições demográfica e epidemiológica, além das condições dos recursos humanos nas instituições de saúde, seu preparo e sua conscientização ${ }^{(54)}$.

Estudo relata que a era dos procedimentos invasivos e altamente sofisticados e o uso clínico dos antibióticos, desde o início do uso da penicilina $\mathrm{G}$ até o recente betalactâmico ( $4^{\mathrm{a}}$ geração), vem sofrendo uma pressão pela administração abusiva e indiscriminada resultando na seleção de espécies resistentes, não só as drogas administradas, mas também a outras drogas que geram expectativas preocupantes para o futuro da antibioticoterapia e seus efeitos $^{(43)}$.

Apesar dos esforços e das contribuições das pesquisas que têm retroalimentado as ações para o controle das $\mathrm{IH}$, ela continua sendo uma ameaça à segurança dos pacientes hospitalizados e contribui para aumentar as taxas de morbi-mortalidades e os custos de internações hospitalares ${ }^{(39)}$. 
O controle das infecções hospitalares engloba vários pontos como: políticas de saúde, recursos administrativos, financeiros, planta física, recursos humanos e envolvimento dos profissionais num processo de trabalho onde haja o conhecimento da existência e presença de microrganismos que representam desafios para as instituições de saúde ${ }^{(39)}$.

Novas propostas de assistência incluem o autocuidado pensando em períodos menores de internação que geram menores riscos e chances de contaminação por infecções hospitalares. A IH é um problema que deve envolver ações com vários focos, desde a aplicação de princípios e normas que cada profissional faz no seu exercício, a observação ativa e sistemática da ocorrência e atuação mediante os fatos observados ${ }^{(43)}$.

Estudo realizado em 2002, com o envolvimento de enfermeiras em várias instituições de saúde mostraram que elas atuam no controle das infecções, mas com desafios para efetivar o controle das mesmas, pois relatam falta de apoio e a escassez de verbas destinadas a sustentar programas de prevenção das $\mathrm{IH}^{(39)}$.

O controle das IH resulta de um esforço conjunto e da adoção de medidas eficazes, pois, em um ambiente hospitalar, os próprios pacientes, a equipe e até os visitantes podem fazer o papel de vetores na transmissão de microrganismos e podem incluir indivíduos com doenças agudas, indivíduos com microrganismos no período de incubação de uma doença, que são colonizadas por agente infeccioso, mas que não tem doença aparente, ou indivíduos que são carreadores crônicos de um agente infeccioso ${ }^{(55)}$. 
As formigas também são classificadas como um vetor mecânico na transmissão de microrganismos. Estudos bacteriológicos mostram que as patas das formigas demonstraram ser veiculadoras de espécies de microrganismos como Staphylococcus aureus, Serratia, Klebsiella, Acinetobacter, Enterobacter, Candida e Enterococcus. Outra pesquisa realizada em uma maternidade pública da cidade do Recife-PE, envolvendo as formigas, revelou que 54,5\% das amostras analisadas apresentaram crescimento bacteriano sendo que das amostras positivas 50 eram bactérias patogênicas consideradas pela literatura como importantes no controle de infecção hospitalar ${ }^{(56,57)}$.

Outras fontes de microrganismos infectantes podem ser a flora endógena e a flora exógena ${ }^{(39,55)}$. Há um consenso entre autores que cerca de $70 \%$ das infecções hospitalares são de origem endógena, sendo esta ocasionada por doenças ou condições clínicas predisponentes, conjugadas com procedimentos invasivos diagnóstico-terapêuticos, agressivos e imunossupressivos. Tais situações geram de um lado o agravamento da susceptibilidade do paciente e do outro a migração e aumento da resistência dos microrganismos de sua própria flora, resultando as infecções ${ }^{(4)}$.

Já a infecção exógena é a ocasionada por microrganismos oriundos do ambiente e dos artigos médicos-hospitalares que são transmitidos ao paciente. Os microrganismos podem estar presentes no ambiente hospitalar, nas mãos dos profissionais ou nos instrumentos, compondo o ambiente não somente por microrganismos primários, mas também de flora humana que pode ser liberada por qualquer pessoa que esteja nesse ambiente, gerando o risco do paciente adquirir uma infecção oriunda dele mesmo ou de outras pessoas ${ }^{(4)}$. 
A infecção hospitalar é a consequência da forma como se desenvolve a assistência, gerando ou não os riscos para o desenvolvimento e transmissão dos microrganismos. O modo de transmissão das infecções hospitalares é dividido em dois subgrupos ${ }^{(4,41,55) \text { : }}$

a) transmissão por contato direto: esse modo de transmissão envolve o contato direto de superfícies corporais e a transferência física de microrganismos entre um hospedeiro suscetível e uma pessoa infectada ou colonizada; como a que ocorre quando uma pessoa muda um paciente de decúbito, realiza um banho no leito ou executa outras atividades de cuidados com pacientes que requeiram contato pessoal direto. Pode também ocorrer entre dois pacientes com um servindo de fonte do agente infeccioso e o outro como hospedeiro suscetível.

b) transmissão por contato indireto: a transmissão por contato indireto envolve o contato de um hospedeiro suscetível com um objeto inanimado contaminado, como instrumentos, agulhas, coberturas de curativos, mãos contaminadas que não foram higienizadas ou luvas que não foram trocadas após procedimentos e cuidados com os pacientes. Antes da manifestação da infecção, o paciente passa por alguns estágios que incluem, além da aquisição da cepa, um período variável de colonização. Tanto o paciente infectado quanto colonizado pode transmitir o microrganismo a pacientes, funcionários ou superfícies de mobiliários do ambiente.

As infecções hospitalares na área pediátrica são consideradas fatores de complicações no tratamento, pois que aumentam a morbidade, mortalidade, 
o tempo de permanência hospitalar, os custos e o sofrimento para a criança e seus acompanhantes/responsáveis. Os serviços que tenham cirurgias apresentam taxas mais elevadas de infecções de sítio cirúrgico, e os que possuem pacientes oncológicos ou com doenças infecto-contagiosas apresentam maiores taxas de risco de infecções hospitalares ${ }^{(35)}$.

Nas enfermarias de Pediatria Geral, as infecções mais frequentes são as pneumonias, infecções de corrente sanguínea, de cavidade oral, de tecidos moles e de pele. As infecções de corrente sanguínea relacionam-se ao uso de dispositivos invasivos ocorrendo a disseminação bacteriana a partir da colonização dos catéteres; para as infecções de cavidade oral, relaciona-se o fato de internações prolongadas com o uso de antibióticos de largo espectro, desnutrição, imunodeficiências e administração de drogas que lesam a mucosa oral e para as infecções de pele e tecidos moles cuja principal relação está na incontinência urinária e fecal, própria de certas idades, deficiências neurológicas e de movimentação, desidratação e edemas ${ }^{(35)}$.

Estudos nos quais a idade é incluída apresentam que 9\% das crianças até um ano contraem infecção hospitalar comparadas a $4 \%$ das crianças maiores de 10 anos. O aumento do número de crianças com imunocomprometimento e que precisam de procedimentos invasivos gera o aumento das infecções. Entre as bactérias de maior relevância clínica e epidemiológica, estão os Staphylococcus aureus, Staphylococcus coagulase negativa, Enterobactérias como Klebsiella sp, Escheirichia coli e Enterobacter sp.,microrganismos não fermentadores como Acinetobacter sp, Pseudomonas aeruginosas, Burkholderia cepacea e Stenotrophomonas maltophilia que são 
encontradas com mais frequência em pacientes oncológicos e fibrocísticos, sendo estes últimos considerados patógenos emergentes e multirresistentes aos antimicrobianos ${ }^{(35)}$.

Segundo o Estatuto da Criança e do Adolescente, art. $12^{(58)}$, é permitida a presença de acompanhantes, inclusive no período noturno com condições adequadas de acomodações para tais, sendo respeitada e obedecida a distância entre berços e camas, que correspondem à distância mínima de 1 metro, e esses acompanhantes devem ser orientados quantos às normas hospitalares e às medidas de prevenção de controle de infecções ${ }^{(35,59)}$.

Os controles de infecção em hospitais pediátricos devem levar em conta sua especificidade pensando na susceptibilidade das crianças. A simplicidade imunológica dessas crianças traduz uma maior via de infecção com importante consequência na sua saúde. Alguns fatores específicos como aleitamento materno, brinquedos e terapias com animais são associados a maiores riscos para infecções no ambiente ${ }^{(60)}$.

Algumas evidências sugerem que há associação entre brinquedos e infecção hospitalar. Estudo realizado utilizando revisão sistemática de literatura considerou essa associação de moderada a forte, encontrando uma relação plausível entre a utilização dos brinquedos e o risco de infecção. Os brinquedos foram colocados no leito de uma UTI Neonatal e avaliados microbiologicamente e, após o seu uso, demonstraram altos níveis de colonização (92\%), concluindo que assim como outros elementos os brinquedos podem ser fontes de infecções hospitalares ${ }^{(61)}$. 
É imperioso o uso adequado de antibióticos, da higienização das mãos, da desinfecção, descontaminação, esterilização, bem como, a utilização de critérios no que concerne ao reuso de artigos. Quanto maior o envolvimento do profissional, maior será a adesão aos protocolos de prevenção e controle da infecção ${ }^{(62)}$.

Estudo observou frequência da não adesão a medidas simples e de alta eficácia para o controle das infecções hospitalares, como lavagem das mãos e incorporação de aparatos para proteção individual e coletiva devido à sensação e percepção dos funcionários de que essas medidas dificultam e atrasam a execução dos seus serviços necessitando que o agente de mudanças transmita credibilidade e tenha perseverança para instalar essas atitudes e fazer com que elas se tornem pertencentes à rotina diária desses funcionários ${ }^{(39)}$.

O impacto da promoção do brincar durante a hospitalização deve ser real e essa ação deve ser estruturada e desenvolvida por profissionais inseridos nas equipes das instituições, do gestor ao auxiliar de enfermagem para que se construa um modelo de atendimento cada vez mais seguro que contemple a complexidade do adoecer e a singularidade de cada indivíduo, pois quando se pensa em atitudes isoladas corre-se o risco da perda e da não repercussão do brincar na dinâmica hospitalar ${ }^{(15)}$.

Sabendo que a hospitalização de uma criança pode trazer além dos riscos psicológicos, os riscos que o ambiente hospitalar facilita para o desenvolvimento de uma infecção e consequentemente atraso da recuperação 
na saúde; e ciente da necessidade de instrumentos que possam amenizar esse risco para infecção e fator de estresse, como os brinquedos e a brinquedoteca, há a preocupação com o fato de que esses sejam transmissores de microrganismos e se espalhem, por causa de os brinquedos serem compartilhados entre várias crianças internadas.

Deve-se considerar que o brinquedo pode ser contagioso, mas do tipo "contágio de divertimento", pois a criança mesmo doente é capaz de demonstrar seu desejo de brincar e com pequenos estímulos ela tenta vincularse com as pessoas e o ambiente ${ }^{(34)}$.

Ciente de que o brinquedo é fundamental no processo de internação como acolhimento, apresentador de melhorias, meio de distração, apoio psicológico e resultante de bem-estar para a criança e sabendo-se que não se pode pensar em processo de internação sem a presença do mesmo, faz-se necessário avaliar se o brinquedo de plástico pode transmitir algum tipo de bactéria e propuser um meio de higienização para reduzir ou eliminar sua presença.

E diante de conclusões em que as publicações sobre o assunto são escassas, há a necessidade de evidências científicas para tornar o ato de brincar seguro, sendo a hipótese formulada para o estudo: os brinquedos utilizados pelas crianças da Unidade de Internação Pediátrica podem ser veículos na transmissão de bactérias. 
2. Objetivas 


\section{OBJETIVOS}

\subsection{Objetivo Geral}

2.1.1- Descrever as condições bacteriológicas dos brinquedos de plástico utilizados na Unidade de Pediatria do Hospital Estadual de Bauru HEB.

\subsection{Objetivos Específicos}

2.2.1. Identificar as bactérias nas mãos das crianças e no brinquedo utilizado nas atividades de brincadeiras na Unidade de Internação Pediátrica do HEB.

2.2.2. Identificar o perfil de resistência aos antibióticos das bactérias isoladas,

2.2.3. Determinar a sensibilidade "in vitro" das bactérias isoladas nos brinquedos frente aos produtos de higiene.

2.2.4. Sugerir recomendações sobre a higienização do brinquedo de plástico na Unidade de Internação Pediátrica do HEB. 
3. Casuística e Métadas 


\section{CASUÍSTICA E MÉTODOS}

Inicialmente será pesquisada a presença de bactérias em mãos e brinquedos utilizados pelas crianças na Unidade de Internação Pediátrica do Hospital Estadual Bauru (HEB) e posteriormente será estudada a forma de desinfecção e prevenção da transmissão de bactérias.

Antes da entrega do brinquedo à criança será realizada a coleta de swab das mãos das crianças, a fim de fortalecer a associação entre os resultados encontrados nos brinquedos e sua origem - mãos. As duas mãos foram objeto de coleta (direita e esquerda).

\subsection{Referencial metodológico}

O estudo presente é descritivo e quantitativo, realizado no HEB. A pesquisa descritiva tem o objetivo de informar sobre a distribuição de um evento, na população, em termos quantitativos ${ }^{(63)}$. Há interesse em apenas observar como ocorre determinada situação e expressar as respectivas frequências de modo apropriado.

Esse tipo de estudo tem como um dos objetivos identificar grupos de risco, o que informa sobre as necessidades e as características dos segmentos que poderiam beneficiar-se de alguma forma de medida saneadora ${ }^{(63)}$. 
A proposta do estudo descritivo é observar como certas situações ocorrem como exemplos: de mortalidade, de morbidade, de pessoas expostas a um risco e de recursos e seus são apresentados através da distribuição de frequências de um evento expressos em tabelas e gráficos ${ }^{(63)}$.

\subsection{Casuística do estudo}

A casuística foi composta por crianças com idade pré-escolar (03 aos 05 anos) e idade escolar (06 aos 10 anos) ${ }^{(64)}$, dos sexos masculinos e femininos, nos meses de Junho a Setembro de 2009.

As crianças com idade pré-escolar têm como marcos de desenvolvimento psicossocial às participações de jogos coletivos progredindo para interativos, segue instruções e brincam com ajuda, depois com supervisão e em seguida, sozinhos, e as crianças em idade escolar têm como marcos importantes saltar, andar em fila, participar de jogos com regras e atividades organizadas e assume a maioria dos cuidados pessoais ${ }^{(64)}$.

O número de participantes em cada faixa de idade foi estabelecido a partir do número de internações que ocorrem na Unidade de Internação Pediátrica do HEB, que em média apresenta 150 internações por mês, que corresponde a 600 crianças no período do estudo. Considerando-se um nível de $95 \%$ de confiança, um erro de estimação da ordem de $10 \%$ e os achados de Davies et al ${ }^{(65)}$ como a proporção das ocorrências de infecção microbiológicas 
a partir do contato com os brinquedos, estimou-se o tamanho amostral mínimo de 85 participantes em cada faixa etária.

A análise estatística foi realizada através de contagens e médias apresentadas em tabelas e gráficos. O Teste de McNemar (1947) foi aplicado para avaliar a significância das mudanças entre os momentos de coletas de swabs, sendo este Teste um método não paramétrico usado em dados nominais para determinar se a frequência entre as linhas e as colunas são iguais ${ }^{(66)}$.

\subsection{Métodos}

\subsubsection{Local do Estudo}

O estudo ocorreu no Hospital Estadual Bauru que é uma instituição de saúde que conta com recursos oriundos da Secretaria do Estado da Saúde do Estado de São Paulo sendo a Faculdade de Medicina de Botucatu (FMB) responsável pela administração do HEB com a interveniência da Fundação para o Desenvolvimento Médico e Hospitalar - FAMESP.

O HEB é uma unidade hospitalar com 381 leitos, que coopera com a FMB no cumprimento de suas finalidades de ensino, pesquisa e assistência ${ }^{(67)}$.

As amostras dos materiais coletados foram processadas no laboratório de Análises Clínicas do próprio hospital. 


\subsubsection{Unidade de Internação Pediátrica}

O estudo foi realizado na Unidade de Internação Pediátrica, que possui 33 leitos para atendimento da faixa etária de 01 mês aos 18 anos de idade, com patologias clínicas e cirúrgicas, provenientes do Pronto Atendimento Infantil de Bauru e Prontos-Socorros da Diretoria Regional de Saúde IV (DRS IV) e Unidade Ambulatorial do HEB.

\subsubsection{Equipe de saúde da unidade de internação pediátrica}

A Unidade possui um quadro de funcionários composto por médicos, fonoaudiólogos, fisioterapeutas, assistente social, psicóloga, nutricionista, enfermeiros, auxiliares de enfermagem e técnicos de enfermagem.

A equipe de Enfermagem é composta por cinco enfermeiros, sendo um denominado coordenador da unidade, responsável pela área administrativa e os outros denominados assistenciais, três auxiliares de enfermagem e 20 técnicos de enfermagem. A jornada de trabalho é variável de acordo com cada categoria profissional.

\subsubsection{Rotinas da unidade de internação pediátrica}

A criança é recebida na Unidade de Internação pelo enfermeiro de plantão e pelo funcionário que irá assistí-la naquele período. No momento da admissão, inicia-se a Sistematização da Assistência de Enfermagem - SAE 
(Exame Físico, Histórico, Diagnósticos de Enfermagem, Prescrição de Enfermagem, Evoluções diárias e Anotações de Enfermagem) sendo as informações descritas no instrumento de registro de SAE do HEB, que serve de comunicação a todos os profissionais envolvidos na assistência da criança.

As crianças são acomodadas em berços ou camas, de acordo com faixa etária, sexo e patologias, no alojamento conjunto. Há ainda na unidade três leitos destinados à assistência a criança com uso de precauções universais ${ }^{(68)}$.

A meta de média de permanência é de três dias, com no mínimo 24 horas de internação, de acordo com o proposto pelo Sistema Único de Saúde (SUS). A unidade de internação pediátrica apresenta prevalência de patologias como: Pneumonia Adquirida na Comunidade, Leishmaniose Visceral Americana e Cardiopatias Congênitas, conforme levantamento realizado nos últimos dois anos no HEB.

Na alta hospitalar, a criança e seu responsável recebem um resumo de alta, denominado "Resumo de Saída" e as orientações dos profissionais de acordo com as necessidades de cuidados no domicílio, inclusive com agendamento de retorno ou encaminhamento.

\subsubsection{Controle de infecções da unidade de internação pediátrica}

A unidade conta com a busca ativa inclusive com tabulação de dados na avaliação da acreditação hospitalar. 


\subsubsection{Brinquedoteca}

A unidade de internação pediátrica possui uma brinquedoteca destinada ao lazer e entretenimento da criança/adolescente e seu acompanhante durante a hospitalização. A brinquedoteca tem acesso livre a todas as crianças/adolescentes e seu acompanhante nas 24 horas do dia e com atividades direcionadas pela psicóloga do hospital, alunos estagiários do curso de psicologia da Universidade Estadual Paulista (UNESP), voluntárias treinadas e do grupo Projeto Alegria pelo setor de humanização do HEB ocorrendo em apenas alguns períodos diurno e noturno.

As atividades na brinquedoteca são coordenadas pela psicóloga da unidade e a manutenção, aquisição dos brinquedos é de responsabilidade do enfermeiro.

Não há uma rotina de higienização para os brinquedos utilizados na brinquedoteca, apenas os voluntários realizam uma higiene em alguns brinquedos com álcool $70 \%$ e esfregaço com tecido limpo, sem rotina estabelecida pela unidade. É permitido o uso de brinquedo de plástico e livros de histórias infantis, gibis e revistas, de acordo com as orientações da SCHI do HEB. Essa norma é válida para o brinquedo terapêutico e o favorito da criança. 


\subsection{Aspectos éticos}

A pesquisa foi previamente submetida ao parecer do Comitê de Ética em Pesquisa da Instituição da Faculdade de Medicina de Botucatu após receber concordância da Comissão Científica do HEB.

As crianças que foram incluídas na pesquisa tiveram seus acompanhantes/responsáveis convidados e após explanação sobre a pesquisa obtinha-se o consentimento e a concordância confirmou-se com a assinatura do Termo de Consentimento Livre e Esclarecido (Apêndice 1).

\subsection{Descrições do brinquedo}

O brinquedo selecionado para a brincadeira e coleta das amostras foi pinos do jogo de boliche, de material totalmente plástico, lavável, atóxico e sem aberturas que facilita a entrada de líquidos ou sujidades. O brinquedo selecionado tem aprovação do Inmetro ( $\left.n^{\circ} 300 / 2000\right)$ e pelo ICEPEX - Instituto de Certificação Expressa de Produtos, órgão responsável por segurança de brinquedos $^{(69)}$. 


\subsection{Descrições dos produtos de higiene utilizados}

Os produtos de higiene selecionados para a realização da pesquisa foram os produtos mais utilizados nos hospitais que possuem brinquedotecas, obtidos por meio da pesquisa intitulada "BRINQUEDOTECA: Processo de higienização no controle de infecção hospitalar", de Iniciação Científica com apoio da Fundação de Amparo à Pesquisa do Estado de São Paulo, desenvolvida por aluna de Graduação de Enfermagem da UNESP- Botucatu. O resultado da pesquisa indicou o uso dos seguintes produtos ${ }^{(70)}$ :

- clorexidina alcoólica $2 \%$

- clorexidina detergente $2 \%$

- álcool $70 \%$

- sabão líquido comum

- $\quad$ hipoclorito de sódio 1\%

Cada produto de higiene possui uma atividade específica com mecânicos de ações diferentes, conforme estudos ${ }^{(71,72)}$ e segue descrito em quadro 1: 
Quadro 1 - Descrição dos produtos de higiene de acordo com sua atividade e mecanismos de ação.

\begin{tabular}{|c|c|c|}
\hline $\begin{array}{l}\begin{array}{c}\text { Produtos de } \\
\text { higiene }\end{array} \\
\end{array}$ & Atividades & Mecanismos de ação \\
\hline \multirow[t]{2}{*}{$\begin{array}{l}\text { Clorexidina } \\
\text { alcoólica } 2 \%\end{array}$} & $\begin{array}{l}\text { - germicida efetivo frente às } \\
\text { bactérias Gram-positivas mais } \\
\text { do que Gram-negativas e } \\
\text { fungos }\end{array}$ & $\begin{array}{l}\text { - afinidade pelas bactérias em } \\
\text { decor rência da adesão da } \\
\text { molécula catiônica à parede } \\
\text { celular aniônica r do } \\
\text { microrganismo }\end{array}$ \\
\hline & \begin{tabular}{|l} 
- não apresenta \\
virucida
\end{tabular} & \\
\hline $\begin{array}{c}\text { Clorexidina } \\
\text { detergente } 2 \%\end{array}$ & $\begin{array}{l}\text { - em associação com álcool } \\
\text { etílico é efetiva contra } \\
\text { bactérias Não fermentadoras }\end{array}$ & $\begin{array}{l}\text { - aumento da permeabilidade } \\
\text { da membrana da bactéria, } \\
\text { abrindo espaços para a } \\
\text { penetração do produto no } \\
\text { citoplasma causando a morte } \\
\text { da bactéria }\end{array}$ \\
\hline \multirow{3}{*}{$\begin{array}{l}\text { Álcool etílico } \\
70 \%\end{array}$} & $\begin{array}{lr}\text { - eficientes contras as formas } \\
\text { vegetativas } \\
\text { microrganismos } \\
\end{array}$ & $\begin{array}{l}\text { - atividade microbiana que } \\
\text { desnatura as proteínas }\end{array}$ \\
\hline & - propriedades bactericidas & $\begin{array}{l}\text { - solventes lipídicos que lesam } \\
\text { as membranas das células } \\
\text { microbianas }\end{array}$ \\
\hline & & $\begin{array}{l}\text { - eficiente como desinfetante } \\
\text { para superfícies devido a ação } \\
\text { de limpeza que auxilia na } \\
\text { remoção mecânica }\end{array}$ \\
\hline $\begin{array}{c}\text { Sabão líquido } \\
\text { comum }\end{array}$ & $\begin{array}{l}\text { - não possui ação na redução } \\
\text { de microrganismos }\end{array}$ & $\begin{array}{l}\text { - remoção mecânica de } \\
\text { sujidades da pele }\end{array}$ \\
\hline \multirow[b]{2}{*}{ Hipoclorito $1 \%$} & $\begin{array}{l}\text { - desinfetante ativo frente a } \\
\text { bactérias, fungos e vírus }\end{array}$ & $\begin{array}{l}\text { - desinfetante que libera ácido } \\
\text { hipocloroso que se decompõe } \\
\text { em cloro e oxigênio livre }\end{array}$ \\
\hline & - pouco ativo frente a esporos & $\begin{array}{l}\text { - inibe as reações enzimáticas } \\
\text { intracelulares, desnatura as } \\
\text { proteínas e inativa ácidos } \\
\text { nucléicos }\end{array}$ \\
\hline
\end{tabular}




\subsection{Etapa Clínica}

\subsubsection{Amostragem}

A amostragem foi composta de crianças internadas na Unidade de Internação Pediátrica do HEB, tendo como:

\section{Critérios de inclusão:}

todas as crianças de 3 a 10 anos de idade com período mínimo de internação de 24 horas, pensando na socialização e adaptação da criança ao ambiente hospitalar ${ }^{(64)}$,

concordância dos responsáveis em assinar o termo de consentimento livre e esclarecido,

não encostar o brinquedo em qualquer superfície.

\section{Critérios de exclusão:}

crianças com limitação de movimentos, que não conseguem manipular o brinquedo somente com as mãos,

crianças com menos de 24 horas de internação,

> não concordância dos pais em assinar o termo de consentimento livre e esclarecido,

$>$ encostar o brinquedo em superfície. 


\subsubsection{Coleta das amostras das mãos}

Para a coleta, utilizou-se do Swab estéril seco após calçar luvas estéreis, sendo sempre realizada na área correspondente à superfície da palma e das bordas, partindo da região dos punhos. De maneira angular, o Swab foi passado com movimentos giratórios, da parte inferior da palma até a extremidade dos dedos e voltando ao punho, repetindo-se esse procedimento três vezes na direção de cada dedo. Os movimentos nas bordas foram de ida e vinda, avançando um dos lados das mãos onde a linha do punho se inicia, passando entre os dedos e encontrado o outro lado da linha do punho.

\subsubsection{Processo de observação e coleta das amostras do brinquedo}

Antes de iniciar a etapa de observação, o brinquedo foi higienizado utilizando o esfregaço com compressa cirúrgica $(45 \mathrm{~cm}$ x $50 \mathrm{~cm})$, esterilizada e embebida com álcool 70\%. A quantidade de álcool utilizada para umidificar a compressa foi de $40 \mathrm{ml}$, de modo que ficasse úmida sem ocorrer gotejamento quando a mesma fosse esfregada na superfície do brinquedo. O brinquedo foi acomodado em caixa de plástico que foi higienizada previamente da mesma maneira que o brinquedo (Figura 1). Todo o procedimento foi realizado com luva estéril. 


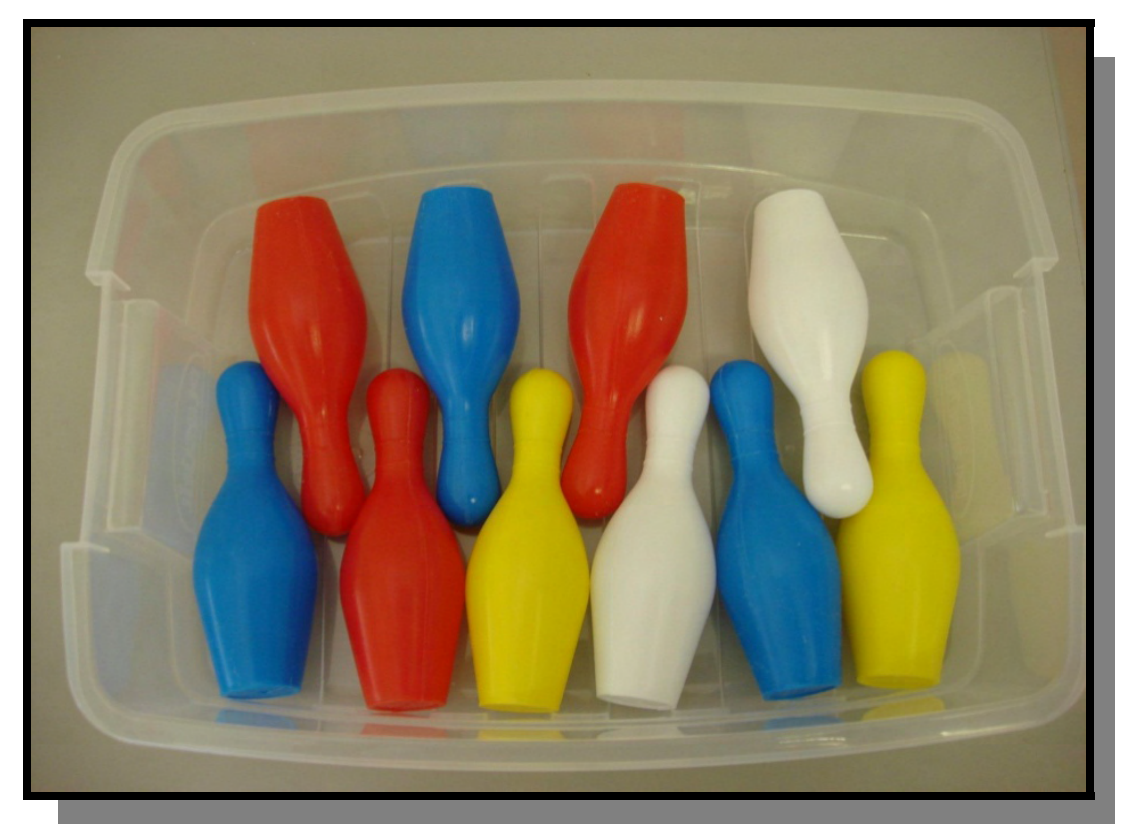

Figura 1- Acomodação dos brinquedos na caixa de plástico.

Seguidamente iniciou-se a coleta das amostras pelo processo de observação, verificando se a criança encontrava-se sozinha no leito ou na brinquedoteca. Foi oferecido o brinquedo a criança selecionada para desenvolver a brincadeira e após 10 minutos, no máximo, o brinquedo foi recolhido, utilizando luva estéril e procedeu-se à amostragem. Outro brinquedo idêntico poderia ser oferecido à criança caso ela quisesse continuar a brincar.

Foi estipulado no máximo 10 minutos de duração de brincadeira, após a revisão da literatura em relação à transmissão por contato direto e o projeto piloto realizado anteriormente. Define-se por contato direto aquele que envolve duas superfícies ${ }^{(41,55)}$. Julgou-se que apenas o contato, sem tempo mínimo determinado, seria o suficiente para a transmissão de microrganismos das mãos das crianças para os brinquedos, confirmando por meio de trabalhos que 
fazem uso de Rodac Plate "Replicate Organisms Direct Agar" que estabelecem o simples contato como determinador de transmissão ${ }^{(43,50,73)}$.

A higienização das mãos é um ato simples e importante no controle das infecções hospitalares, visto que a pele tem a capacidade de abrigar microrganismos e transferí-los de uma superfície para outra por contato direto e indireto ${ }^{(37,48-50)}$.

A coleta transcorreu durante os meses de junho, julho, agosto e Setembro de 2009, considerando apenas os dias úteis, para a observação e coleta das amostras. A escolha do período foi aleatória.

O total de crianças observadas foi de 180, subdivididas em pré-escolar (90) e escolar (90), perfazendo um total de 900 amostras, considerando todos os momentos de coleta de amostragem, pois para cada criança observada foi coletada uma amostra de Swab da mão direita e da esquerda e mais 3 amostras no brinquedo, conforme descrição:

Iniciou-se a coleta realizando esfregaço com a zaragatoa estéril seca, da região superior para a inferior, dividindo o brinquedo em quadro lados e seguidamente foi oferecido o brinquedo à criança. Aguardou-se o período máximo de dez minutos ou solicitou-se o brinquedo antes que o mesmo entrasse em contato com outra criança ou a superfície.

Após a brincadeira, recebeu o brinquedo utilizando-se luvas estéreis, onde se segurou somente a porção superior do brinquedo (pino) e realizou-se novamente o esfregaço com a zaragatoa estéril seca, da mesma maneira como na primeira amostra e armazenou-se a zaragatoa no gel Stuart. 
Seguidamente realizou-se a higiene do brinquedo com compressa cirúrgica umedecida com $40 \mathrm{ml}$ de álcool 70\% e coletou-se a terceira amostra com zaragatoa estéril seca do brinquedo higienizado. Todas as amostras da coleta foram encaminhadas ao laboratório de Análises Clínicas do HEB. As etapas seguem descritas em Fluxograma 1.

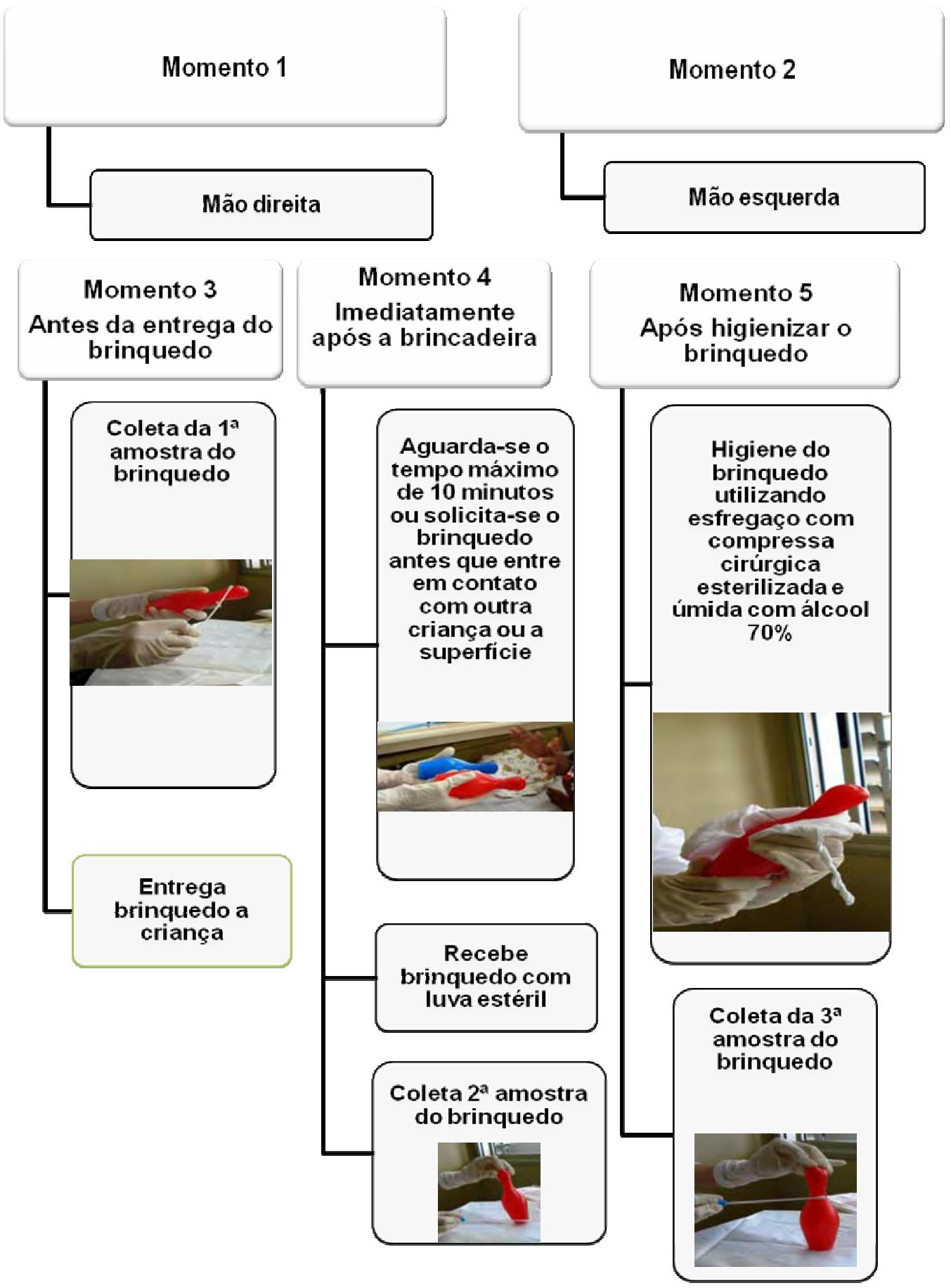

Fluxograma 1 - Coletas das amostras. 


\subsection{Etapa laboratorial}

As amostras coletadas foram encaminhadas no meio de transporte Stuart (gel) ao laboratório para a realização da identificação de microrganismos de acordo com a rotina do HEB.

Cada amostra foi identificada numericamente em ordem crescente de acordo com sujeito da pesquisa e os momentos de coleta, por exemplo:

1PEMD: primeira amostra do pré-escolar da mão direita

1PEME: primeira amostra do pré-escolar da mão esquerda

1PEA: primeira amostra do pré-escolar antes

1PEI: primeira amostra do pré-escolar imediatamente

1PEH: primeira amostra do pré-escolar após higiene

1EMD: primeira amostra do escolar da mão direita

1EME: primeira amostra do escolar da mão esquerda

1EA: primeira amostra do escolar antes

1El: primeira amostra do escolar imediatamente

1EH: primeira amostra do escolar após higiene

\subsubsection{Semeadura das amostras}

A semeadura foi realizada nos meios de cultura Ágar MacConkey e Manitol, manipulados próximos a chama do bico de Bunsen. As placas de Petri e os Swabs foram incubados a $37^{\circ} \mathrm{C}$ por 24 horas e analisou o crescimento bacteriano. Quando não houve crescimento bacteriano, as placas de Petri foram submetidas novamente à incubação por mais 24 horas a $37^{\circ} \mathrm{C}$, para determinar se a amostra é ou não negativa ${ }^{(74)}$. 


\subsubsection{Análise das placas de Petri semeadas}

O crescimento de colônias na placa de Petri contendo o meio de cultura Ágar MacConkey é indicativo de presença de bactérias Gram-negativas e a placa de Petri contendo meio de cultura Manitol indica presença de bactérias Gram-positivas $^{(74)}$.

As placas de Petri com presença de crescimento bacteriano foi analisada pelas características morfotintoriais das colônias e pela coloração do Gram, de acordo com as normas estabelecidas pelo Laboratório de Análises Clínicas do HEB.

Após identificar a presença de bactérias ou não, nas respectivas placas de Petri, foi dada a sequência de análise com as respectivas provas de identificação de acordo com o protocolo do laboratório de Análises Clínicas do HEB.

\subsubsection{Teste de sensibilidade dos produtos de higienização}

Foi realizado teste de sensibilidade "in vitro", utilizando o método de difusão em Gel de Ágar ${ }^{(74)}$, nas amostras de bactérias de maior prevalência, isoladas dos brinquedos. Os produtos utilizados para a realização do teste dos brinquedos de plástico foram: água e sabão, álcool 70\%, hipoclorito 1\%, clorexidina detergente $2 \%$ e clorexidina alcoólico $2 \%$, utilizando $0,1 \mathrm{ml}$ de cada produto, em triplicata. 
Foram preparados discos de papel filtro estéreis, com dimensões de 6 $\mathrm{mm}$, semelhantes aos utilizados nos testes de antibiograma, contendo 0,1 ml de solução do produto de higienização e para controle foram utilizados discos contendo $0,1 \mathrm{ml}$ de solução salina.

Após a colonização das placas Ágar MacConkey e/ou Manitol, retiraramse com uma alça descartável estéril colônias bacterianas presentes e transferiram-se para um tubo contendo aproximadamente $3 \mathrm{ml}$ de solução salina 0,85\% estéril sendo agitado de modo a atingir uma turvação equivalente à do padrão $n^{0} 5$ da escala MacFarland ${ }^{(74)}$.

Foi submerso um Swab de algodão atóxico e estéril na suspensão bacteriana e antes de retirá-lo, eliminou-se o excesso de líquido apertando-o contra a parede do tubo e realizou-se a semeadura sobre a superfície seca da Placa de Petri que continha meio de cultura Ágar Muller-Hinton, mantida em temperatura ambiente, em repouso entre 5 a 10 minutos para secagem, antes da colocação dos discos de papel filtro.

Os discos foram colocados com pelo menos três centímetros de distância entre eles, incubando-as por 48 horas a $37^{\circ} \mathrm{C}$.

Após a incubação, foram analisados os tamanhos dos halos formados ao redor dos discos. A sensibilidade foi medida através da média do tamanho dos três halos determinando a sensibilidade do produto de higiene frente à bactéria analisada. 
Para determinar a sensibilidade ou a resistência do produto de higiene em relação à determinada bactéria, dividiram-se os tamanhos dos halos em três grupos, sendo os que possuem de $1 \mathrm{~mm}$ a $6 \mathrm{~mm}$ denominados de pouco sensível, os que possuem de $7 \mathrm{~mm}$ à $12 \mathrm{~mm}$ denominados de sensível e os que apresentaram resultado igual a zero denominados de resistente.

As bactérias tornam-se resistentes quando algumas delas produzem enzimas que modificam a parte ativa da molécula do antibacteriano onde essas novas enzimas não sofrem a ação do antibiótico. Ocorre a alteração do sítio de ação e a expulsão do antibacteriano ${ }^{(75)}$.

\subsubsection{Variáveis do estudo}

As variáveis do estudo são apresentadas em: variável dependente, variáveis complementares e variáveis de análise bacteriológica.

\subsubsection{Variável dependente e variáveis complementares}

As variáveis foram selecionadas por permitirem verificar a característica de similaridade entre os grupos. Selecionou-se: idade - Variável Dependente, sexo, mão dominante, hipótese médica de diagnóstico, tipo de patologia, horário da coleta, antibioticoterapia, lesões de pele, presença de catéteres invasivos e presença de incisões cirúrgicas - Variáveis Complementares (Anexo 1). 


\section{IDADE}

A idade da criança foi medida por meio do registro de data de nascimento na abertura do prontuário na admissão da criança, sendo medida em anos.

\section{SEXO}

A fim de caracterizar a amostra, elegeu-se a variável, dicotomizada em:

- Masculino

- Feminino

\section{> MÃO DOMINANTE}

Esta variável foi selecionada a fim de obter dados para aproximar a associação entre amostras positivas e o uso da mão que envolveu o brinquedo, sugerindo ser esta a mão que a mesma utiliza para a realização da maior parte de suas atividades.

\section{HIPÓTESE MÉDICA DE DIAGNÓSTICO}

Os diagnósticos gerados na internação da criança foram classificados segundo sua natureza em:

- Cirúrgico (pós-operatório)

- Clínico 
Selecionou-se essa variável devido à possibilidade da influência sobre a amostra estudada, pois a Unidade de Internação Pediátrica recebe diversas crianças com diferentes tipos de patologias.

As crianças com patologias de bases clínicas, dependendo do tipo e graus de disfunção orgânica apresentadas, podem desenvolver maiores riscos para infecções hospitalares. As crianças admitidas para procedimentos cirúrgicos eletivos podem estar menos debilitadas diante das crianças em recuperação de patologias clínicas, e subentende-se que essas tenham menos riscos de adquirir infecções hospitalares por estarem previamente fora do ambiente hospitalar, porém, devido ao procedimento cirúrgico, podem apresentar maior quantidade de dispositivos invasivos ${ }^{(64)}$.

\section{$>\quad$ TIPO DE PATOLOGIA}

Classificou-se a patologia que gerou internação hospitalar em:

- Aguda

- Crônica

- Moléstia Infecciosa

\section{HORÁRIO DA COLETA}

Selecionou-se essa variável, pois a rotina de higienização da Unidade de Internação Pediátrica ocorre no período da manhã indicando que no período da tarde, após as atividades na brinquedoteca e ou procedimentos, há maior exposição da criança com outras crianças, equipe da unidade e objetos. 


\section{$>$ ANTIBIOTICOTERAPIA}

Visando associar as crianças que poderiam ter características de colonização de pele alteradas necessitando do uso de antibióticos. Classificouse essa variável em:

- $\operatorname{Sim}$

- Não

- Tratamento profilático

- $\operatorname{Sim}$

- Não

- Pesquisa de cultura (sangue ou urina)

- $\operatorname{Sim}$

- Não

- História de hipertermia (no dia da coleta)

- $\operatorname{Sim}$

- Não 


\section{$>\quad$ LESÕES DE PELE}

Tal variável foi selecionada para obter e identificar as crianças que apresentam maiores riscos para infecções e condições que possibilitem uma maior aderência de microrganismos à superfície da pele facilitando assim a colonização da pele ${ }^{(60)}$.

\section{Considerou-se:}

- Com lesões de pele: aquelas com cortes, fissuras, abrasões e lesões, com ou sem presença de secreção.

- Sem lesões de pele: aquelas com pele íntegra.

\section{$>$ PRESENÇA DE CATÉTERES INVASIVOS E INCISÕES CIRÚRGICAS}

Essa variável foi selecionada pensando em identificar se as crianças que necessitem de procedimentos e artifícios invasivos estão mais sujeitas a infecções hospitalares, uma vez que passaram por procedimentos que a deixaram expostas a riscos maiores para a entrada de microrganismos. Considerou-se o uso de artifícios como: catéteres venosos centrais, acessos venosos periféricos, sonda nasogástrica e/ou enteral, sonda vesical de demora e/ou Intermitente e Incisões cirúrgicas ${ }^{(64)}$. 


\subsubsection{Variáveis da análise bacteriana}

Estas variáveis relacionam-se com os aspectos da análise bacteriana realizada, ocorrendo o estudo de: presença de bactéria, ausência de bactéria, tipos de bactérias, sensibilidade da bactéria encontrada com produto de higiene (Anexo 2).

$>$ Presença

Ausência

- Tipo de Bactéria

Sensibilidade da bactéria encontrada com produto de higiene, representada por presença de halo:

- água e sabão

- Sim

- Não

- Álcool etílico (70\%)

- Sim

- Não

- hipoclorito 1\% (1\%)

- Sim

- Não 
- clorexidina detergente (2\%)

- Sim

- Não

- clorexidina alcoólico (2\%)

- Sim

- Não 
4. Resultdas 


\section{RESULTADOS}

A amostra foi constituída de 180 crianças, sendo 90 pré-escolares e 90 escolares. Deste total, 95 são do sexo masculino e 85 do sexo feminino, havendo predomínio de internações de crianças com diagnósticos médicos classificados em clínicos (95 casos) e cirúrgicos (85 casos).

Percebe-se o uso da mão direita como predominante em 159. Do total de 180 amostras, 135 crianças apresentaram crescimento bacteriano na mão direita e 124 na mão esquerda, conforme mostra Tabela 1. Esta Tabela mostra ainda, percentual maior de crescimento bacteriano na mão direita do escolar $(51,85 \%)$.

Tabela 1 - Distribuição de frequência e percentual em relação à presença de bactérias nas mãos das crianças em idades pré-escolares e escolares. Bauru, 2009.

\begin{tabular}{l|cc|cc}
\hline \multicolumn{5}{c}{ PRESENÇA DE BACTÉRIAS } \\
\hline \multirow{2}{*}{ ESCOLARIDADE } & \multicolumn{2}{|c|}{ MÃO DIREITA } & \multicolumn{2}{c}{ MÃO ESQUERDA } \\
\cline { 2 - 5 } & $\begin{array}{c}\text { Freqüência } \\
\text { (N) }\end{array}$ & $\begin{array}{c}\text { Percentual } \\
\text { (\%) }\end{array}$ & $\begin{array}{c}\text { Freqüência } \\
\text { (N) }\end{array}$ & $\begin{array}{c}\text { Percentual } \\
\text { (\%) }\end{array}$ \\
\hline Pré-Escolar & 65 & 48,15 & 62 & 50,00 \\
Escolar & 70 & 51,85 & 62 & 50,00 \\
\hline Total & 135 & 100,00 & 124 & 100,00 \\
\hline
\end{tabular}

Do total de amostras que apresentaram crescimento bacteriano nas mãos das crianças hospitalizadas, percebe-se presença maior nas amostras das crianças do sexo masculino na mão direita $(54,81 \%)$ e esquerda $(51,60 \%)$, conforme demonstrado na Tabela 2. 
Tabela 2 - Distribuição de frequência e percentual em relação à presença de bactérias nas mãos das crianças e sexo. Bauru, 2009.

\begin{tabular}{c|cc|cc}
\hline \multicolumn{5}{c}{ PRESENÇA DE BACTÉRIAS } \\
\hline \multirow{2}{*}{ SEXO } & \multicolumn{2}{|c|}{ MÃO DIREITA } & \multicolumn{2}{|c}{ MÃO ESQUERDA } \\
\cline { 2 - 5 } & $\begin{array}{c}\text { Freqüência } \\
(\mathrm{N})\end{array}$ & $\begin{array}{c}\text { Percentual } \\
(\%)\end{array}$ & $\begin{array}{c}\text { Freqüência } \\
(\mathrm{N})\end{array}$ & $\begin{array}{c}\text { Percentual } \\
(\%)\end{array}$ \\
\hline Feminino & 61 & 45,19 & 60 & 48,40 \\
Masculino & 74 & 54,81 & 64 & 51,60 \\
\hline Total & 135 & 100,00 & 124 & 100,00 \\
\hline
\end{tabular}

Do total de amostras que apresentaram algum tipo de crescimento bacteriano nas mãos das crianças hospitalizadas, obteve-se maior presença de bactéria Stafilococcus coagulase negativa tanto para mão direita como para a mão esquerda, nas duas faixas etárias estudadas - pré-escolar e escolar. Ressalva ainda que em relação à faixa etária amostrada, houve percentual maior de crescimento bacteriano na mão direita da criança em idade escolar, quando comparado com a faixa etária do pré-escolar; já para a mão esquerda, o maior percentual encontrado foi a faixa etária do pré-escolar, conforme ilustrado na Tabela 3. 
Tabela 3 - Descrição de frequência e percentual em relação às bactérias isoladas da mão direita e esquerda do pré-escolar e escolar. Bauru, 2009.

\begin{tabular}{|c|c|c|c|c|c|c|c|c|}
\hline \multirow{3}{*}{$\begin{array}{l}\text { BACTÉRIAS } \\
\text { ISOLADAS }\end{array}$} & \multicolumn{4}{|c|}{ PRÉ-ESCOLAR } & \multicolumn{4}{|c|}{ ESCOLAR } \\
\hline & \multicolumn{2}{|c|}{ Mão direita } & \multicolumn{2}{|c|}{$\begin{array}{c}\text { Mão } \\
\text { esquerda }\end{array}$} & \multicolumn{2}{|c|}{ Mão direita } & \multicolumn{2}{|c|}{$\begin{array}{c}\text { Mão } \\
\text { esquerda } \\
\end{array}$} \\
\hline & $\mathbf{N}$ & $\%$ & $\mathbf{N}$ & $\%$ & $\mathbf{N}$ & $\%$ & $\mathbf{N}$ & $\%$ \\
\hline $\begin{array}{l}\text { Stafilococcus } \\
\text { coagulase } \\
\text { negativa }\end{array}$ & 61 & 93,87 & 56 & 90,33 & 62 & 88,58 & 55 & 88,71 \\
\hline $\begin{array}{l}\text { Stafilococcus } \\
\text { aureus }\end{array}$ & 0 & 0,00 & 0 & 0,00 & 4 & 5,72 & 5 & 8,07 \\
\hline $\begin{array}{l}\text { Pseudomonas } \\
\text { aeruginosa }\end{array}$ & 2 & 3,07 & 1 & 1,61 & 1 & 1,42 & 1 & 1,61 \\
\hline Acinetobacter & 1 & 1,53 & 2 & 3,23 & 1 & 1,42 & 0 & 0,00 \\
\hline Escheirichia coli & 0 & 0,00 & 0 & 0,00 & 0 & 0,00 & 1 & 1,61 \\
\hline $\begin{array}{l}\text { Stafilococcus } \\
\text { coagulase } \\
\text { negativa } \\
\text { Stafilococcus } \\
\text { aureus }\end{array}$ & 1 & 1,53 & 1 & 1,61 & 0 & 0,00 & 0 & 0,00 \\
\hline $\begin{array}{l}\text { Stafilococcus } \\
\text { aureus } \\
\text { Pseudomonas }\end{array}$ & 0 & 0,00 & 1 & 1,61 & 0 & 0,00 & 0 & 0,00 \\
\hline $\begin{array}{l}\text { Stafilococcus } \\
\text { coagulase } \\
\text { negativa } \\
\text { Pseudomonas }\end{array}$ & 0 & 0,00 & 1 & 1,61 & 2 & 2,86 & 0 & 0,00 \\
\hline TOTAL & 65 & 100,00 & 62 & 100,00 & 70 & 100,00 & 62 & 100,00 \\
\hline
\end{tabular}


A Tabela 4 ilustra a presença bacteriana nos momentos antes da entrega do brinquedo (momento $3=\mathrm{M} 3$ ) e imediatamente após o término da brincadeira da criança (momento $4=M 4$ ). Observa-se que houve maior crescimento bacteriano no brinquedo imediatamente após a brincadeira (68 amostras) quando comparado com outro momento que apresentou 15 amostras com presença de bactérias. Esta tabela mostra também que em M3 há 15 amostras com crescimento bacteriano onde 12 amostras permaneceram com o mesmo resultado em M4.

$\mathrm{Na}$ análise do Teste de McNemar, verificaram-se alterações significativas $(P<0,001)$ das frequências de respostas entre os momentos M3 e M4.

Tabela 4 - Distribuição da frequência e percentual em relação à presença e ausência de bactérias encontradas nas amostras dos brinquedos no momento antes da brincadeira e imediatamente após a brincadeira. Bauru, 2009.

\begin{tabular}{|c|c|c|c|}
\hline $\begin{array}{ll}\mathrm{M} 3 & \mathrm{M} 4 \\
\end{array}$ & PRESENÇA & AUSÊNCIA & TOTAL \\
\hline PRESENÇA & 12 & 3 & 15 \\
\hline AUSÊNCIA & 57 & 108 & 165 \\
\hline TOTAL & 68 & 111 & 180 \\
\hline
\end{tabular}

$X^{2}=48,61(P<0,001)$

LEGENDA: M3= Momento 3: antes da entrega do brinquedo à criança.

M4= Momento 4: imediatamente após o término da brincadeira da criança.

A Tabela 5 ilustra a presença de crescimento bacteriano nos momentos antes da entrega do brinquedo (M3) e depois do processo de higienização realizado por esfregaço com compressa umidificada com álcool 70\% estéril (M5). Pode-se notar nesta Tabela que do total de 15 amostras com crescimento bacteriano em M3, há oito amostras que permaneceram com crescimento bacteriano em M5. 
Essa Tabela traz também que do total de 165 amostras com ausência de crescimento bacteriano apresentado em M3, há 135 amostras que mantiveram o resultado de ausência de crescimento bacteriano em M5.

Um dado que desperta atenção na Tabela 5 é relacionado ao resultado da amostra do brinquedo após a higienização, pois conforme demonstrado, houve apenas a redução das bactérias e não a eliminação total das mesmas.

A Tabela 5 apresenta resultado significativo conforme análise realizada com o Teste de McNemar onde há $X^{2}=17,63$ sendo $P<0,001$ significante de alterações entre as frequências de respostas entre os momentos M3 e M5.

Tabela 5 - Distribuição de frequência e percentual em relação à presença de bactérias encontradas nas amostras dos brinquedos no momento antes da brincadeira e depois da higienização do brinquedo. Bauru, 2009.

\begin{tabular}{|c|c|c|c|}
\hline $\begin{array}{ll}\text { M3 } & \text { M5 } \\
\end{array}$ & PRESENÇA & AUSÊNCIA & TOTAL \\
\hline PRESENÇA & 8 & 7 & 15 \\
\hline AUSÊNCIA & 30 & 135 & 165 \\
\hline TOTAL & 38 & 142 & 180 \\
\hline
\end{tabular}

$\mathrm{X}^{2}=17,63(\mathrm{P}<0,001)$

LEGENDA: M3= Momento 3: antes da entrega do brinquedo à criança. M5= Momento 5: depois do processo de higienização do brinquedo.

A Tabela 6 representa a presença bacteriana nos momentos imediatamente após o término da brincadeira da criança (M4) e depois do processo de higienização realizado por esfregaço com compressa umidificada com álcool 70\% estéril (M5). Traz como resultado que das 68 amostras em M4 
com crescimento bacteriano, 31 amostras apresentam também crescimento bacteriano em M5. Essa Tabela também mostra a redução das bactérias presentes em M4 (31) e não a eliminação total das mesmas em M5 (7).

Para esses dados, aplicou-se o Teste de McNemar e verificaram-se alterações significativas $(P<0,001)$ das frequências de respostas entre os momentos M3 e M5.

Tabela 6 - Distribuição de frequência e percentual em relação à presença de bactérias encontradas nas amostras dos brinquedos no momento imediato após a brincadeira e depois da higienização do brinquedo. Bauru, 2009.

\begin{tabular}{|c|c|c|c|}
\hline $\begin{array}{ll}\text { M4 } & \text { M5 }\end{array}$ & PRESENÇA & AUSÊNCIA & TOTAL \\
\hline PRESENÇA & 31 & 38 & 68 \\
\hline AUSÊNCIA & 7 & 104 & 111 \\
\hline TOTAL & 38 & 142 & 180 \\
\hline
\end{tabular}

$\mathrm{X}^{2}=21,36(\mathrm{P}<0,001)$

LEGENDA: M4= Momento 4: imediatamente após o término da brincadeira da criança. M5= Momento 5: depois do processo de higienização do brinquedo.

Os dados da Tabela 7 mostram maior percentual de amostras com ausência de bactérias em todos dos momentos, sendo 91,60\% no momento antes da brincadeira (M3), 62,20\% no momento imediato após a brincadeira (M4) e 78,80\% no momento depois do processo de higienização do brinquedo (M5). E entre todos os momentos de coletas de swabs no brinquedo, o M4 foi o que apresentou maior percentual de presença de bactérias, sendo 37,70\%. 
Tabela 7 - Distribuição de frequência e percentual em relação à presença e ausência de bactérias no momento antes da brincadeira, imediato após a brincadeira e depois da higienização do brinquedo. Bauru, 2009.

\begin{tabular}{l|cc|cc|cc}
\hline \multicolumn{1}{|c}{ MOMENTOS } \\
\hline \multirow{2}{*}{ BACTÉRIAS } & \multicolumn{3}{|c}{ M3 } & \multicolumn{2}{c}{ M4 } & \multicolumn{2}{c}{ M5 } \\
\cline { 2 - 8 } & $\begin{array}{c}\text { FREQUÊNCIA } \\
\text { (N) }\end{array}$ & $\begin{array}{c}\text { PERCENTUAL } \\
(\%)\end{array}$ & $\begin{array}{c}\text { FREQUÊNCIA } \\
\text { (N) }\end{array}$ & $\begin{array}{c}\text { PERCENTUAL } \\
(\%)\end{array}$ & $\begin{array}{c}\text { FREQUÊNCIA } \\
\text { (N) }\end{array}$ & $\begin{array}{c}\text { PERCENTUAL } \\
(\%)\end{array}$ \\
\hline PRESENÇA & 15 & 8,40 & 68 & 37,70 & 38 & 2,20 \\
AUSÊNCIA & 165 & 91,60 & 112 & 62,20 & 142 & 78,80 \\
\hline TOTAL & 180 & 100,00 & 180 & 100,00 & 180 & 100,00 \\
\hline
\end{tabular}

LEGENDA: M3= Momento 3: antes da entrega do brinquedo à criança.

M4= Momento 4: imediatamente após o término da brincadeira da criança.

M5= Momento 5: depois do processo de higienização do brinquedo.

A Tabela 8 representa a descrição das bactérias isoladas no momento antes da brincadeira (M3), no momento imediatamente após a brincadeira (M4) e no momento depois do processo de higienização do brinquedo (M5) onde a bactéria Stafilococcus coagulase negativa apresentou o maior percentual de presença em todos os momentos, apresentando em M4 o percentual de $95,50 \%$.

Esta Tabela mostra ainda que há o crescimento de Stafilococcus aureus, Pseudomonas e Acinetobacter em M4, sendo todas com o percentual de 1,50\%, porém com redução total dessas bactérias após o processo de higienização (M5). 
Tabela 8 - Descrição de frequências e percentuais de bactérias isoladas nas amostras dos brinquedos no momento antes da brincadeira, imediato após a brincadeira e depois da higienização do brinquedo. Bauru, 2009.

\begin{tabular}{|c|c|c|c|c|c|c|}
\hline \multicolumn{7}{|c|}{ MOMENTOS DE COLETAS } \\
\hline \multirow{2}{*}{$\begin{array}{l}\text { BACTÉRIAS } \\
\text { ISOLADAS }\end{array}$} & \multicolumn{2}{|c|}{ M3 } & \multicolumn{2}{|c|}{ M4 } & \multicolumn{2}{|c|}{ M5 } \\
\hline & $\begin{array}{l}\text { FREQUÊNCIA } \\
\text { (N) }\end{array}$ & $\begin{array}{c}\text { PERCENTUAL } \\
\text { (\%) }\end{array}$ & $\begin{array}{l}\text { FREQUÊNCIA } \\
\text { (N) }\end{array}$ & $\begin{array}{c}\text { PERCENTUAL } \\
(\%)\end{array}$ & $\begin{array}{l}\text { FREQUÊNCIA } \\
\text { (N) }\end{array}$ & $\begin{array}{c}\text { PERCENTUAL } \\
(\%)\end{array}$ \\
\hline $\begin{array}{l}\text { Stafilococcus } \\
\text { coagulase } \\
\text { negativa }\end{array}$ & 15 & 100,00 & 65 & 95,50 & 38 & 100,00 \\
\hline $\begin{array}{l}\text { Stafilococcus } \\
\text { aureus }\end{array}$ & 0 & 0,00 & 1 & 1,50 & 0 & 0,00 \\
\hline Acinetobacter & 0 & 0,00 & 1 & 1,50 & 0 & 0,00 \\
\hline Pseudomonas & 0 & 0,00 & 1 & 1,50 & 0 & 0,00 \\
\hline TOTAL & 15 & 100,00 & 68 & 100,00 & 38 & 100,00 \\
\hline
\end{tabular}

LEGENDA: M3= Momento 3: antes da entrega do brinquedo à criança.

M4= Momento 4: imediatamente após o término da brincadeira da criança.

M5= Momento 5: depois do processo de higienização do brinquedo.

A Tabela 9 mostra que houve crescimento bacteriano ora na mão direita e ora na mão esquerda, com algumas amostras que apresentaram bactérias nas duas mãos. Para o total de 90 amostras, referente à coleta de swab das mãos, observam-se 70 amostras com crescimento bacteriano onde 65 amostras apresentaram crescimento bacteriano na mão direita e 62 amostras na mão esquerda.

Na mão direita, conforme demonstrados nessa Tabela, foram encontrados: Stafilococcus coagulase negativa (62), Pseudomonas aeruginosa (duas), Stafilococcus aureus (uma) e Acinetobacter (uma), observando que 
uma amostra apresentou mais de um tipo de bactéria na mesma mão, sendo a amostra 12 PE com Stafilococcus coagulase negativa e Stafilococcus aureus.

Para a mão esquerda, a Tabela 9 mostra a presença de Stafilococcus aureus (duas), Pseudomonas aeruginosa (três), Stafilococcus coagulase negativa (58) e Acinetobacter (duas), onde há três amostras com dois tipos de bactérias, sendo 1PE com Stafilococcus aureus e Pseudomonas aeruginosas, 7PE Stafilococcus coagulase negativa e Pseudomonas e 12PE Stafilococcus coagulase negativa e Stafilococcus aureus.

A Tabela 9 apresenta que para M3, momento anterior à brincadeira, há crescimento de Stafilococcus coagulase negativa em oito amostras, para o M4, momento imediato após a brincadeira há crescimento de Stafilococcus coagulase negativa em 35 amostras seguido de uma Pseudomonas aeruginosas e um Acinetobacter. Para M5, momento depois do processo de higienização com álcool $70 \%$, essa Tabela mostra que houve crescimento bacteriano em 20 amostras onde três delas apresentaram resultado com o mesmo tipo de bactéria nas mãos e 17 amostras apresentaram crescimento bacteriano em M3 ou M4, sendo do mesmo tipo.

Esta Tabela ilustra ainda que há amostras que apresentaram diferentes crescimentos bacterianos, ou seja, uma mesma amostra com resultados diferentes dependendo do momento de coleta do swab como as amostras:

$\checkmark$ 1PE com Stafilococcus coagulase negativa na mão direita, Stafilococcus aureus e Pseudomonas aeruginosa na mão esquerda e Stafilococcus coagulase negativa em M4, 
$\checkmark$ 37PE com Stafilococcus coagulase negativa na mão direita e esquerda e Pseudomonas aeruginosa em M4,

$\checkmark$ 81PE que apresenta na mão direita Stafilococcus coagulase negativa, na mão esquerda Acinetobacter e em M4 Stafilococcus coagulase negativa. 
Tabela 9 - Descrição das bactérias isoladas nas amostras das mãos e dos brinquedos das crianças em idade pré-escolar. Bauru, 2009.

\begin{tabular}{|c|c|c|c|c|c|}
\hline \multicolumn{6}{|c|}{ BACTÉRIAS ISOLADAS } \\
\hline AMOSTRA & MÃO DIREITA & $\begin{array}{c}\text { MÃO } \\
\text { ESQUERDA } \\
\end{array}$ & M3 & M4 & M5 \\
\hline $1 \mathrm{PE}$ & SCN & $\begin{array}{c}\text { S. aureus } \\
\text { P. aeruginosa }\end{array}$ & * & SCN & * \\
\hline $2 \mathrm{PE}$ & SCN & SCN & * & * & * \\
\hline $3 \mathrm{PE}$ & SCN & SCN & * & * & SCN \\
\hline $4 \mathrm{PE}$ & * & * & * & * & * \\
\hline $5 \mathrm{PE}$ & SCN & $S C N$ & * & * & * \\
\hline $6 \mathrm{PE}$ & SCN & SCN & * & * & * \\
\hline $7 \mathrm{PE}$ & P. aeruginosa & $\begin{array}{c}S C N \\
\text { P. aeruginosa }\end{array}$ & * & * & * \\
\hline $8 \mathrm{PE}$ & SCN & SCN & * & * & * \\
\hline $9 \mathrm{PE}$ & SCN & * & * & * & * \\
\hline $10 \mathrm{PE}$ & * & SCN & * & * & * \\
\hline $11 \mathrm{PE}$ & SCN & SCN & * & * & * \\
\hline $12 \mathrm{PE}$ & $\begin{array}{c}\text { SCN } \\
\text { S. aureus }\end{array}$ & $\begin{array}{c}\text { SCN } \\
\text { S. aureus }\end{array}$ & * & * & * \\
\hline $13 \mathrm{PE}$ & SCN & SCN & * & * & * \\
\hline $14 \mathrm{PE}$ & SCN & SCN & * & SCN & * \\
\hline $15 \mathrm{PE}$ & * & $P$. aeruginosa & * & * & * \\
\hline $16 \mathrm{PE}$ & P. aeruginosa & SCN & * & * & * \\
\hline $17 \mathrm{PE}$ & SCN & SCN & * & * & * \\
\hline $18 \mathrm{PE}$ & SCN & SCN & * & * & * \\
\hline $19 \mathrm{PE}$ & SCN & SCN & * & * & * \\
\hline $20 \mathrm{PE}$ & SCN & SCN & * & * & * \\
\hline $21 \mathrm{PE}$ & SCN & SCN & * & SCN & * \\
\hline $22 \mathrm{PE}$ & SCN & * & * & * & * \\
\hline $23 \mathrm{PE}$ & * & * & * & * & * \\
\hline $24 \mathrm{PE}$ & SCN & SCN & * & SCN & * \\
\hline $25 \mathrm{PE}$ & SCN & SCN & * & * & * \\
\hline $26 \mathrm{PE}$ & SCN & SCN & * & * & * \\
\hline $27 \mathrm{PE}$ & SCN & SCN & * & SCN & SCN \\
\hline $28 \mathrm{PE}$ & SCN & * & * & SCN & SCN \\
\hline $29 \mathrm{PE}$ & SCN & * & * & * & * \\
\hline $30 \mathrm{PE}$ & Acinetobacter & Acinetobacter & * & * & * \\
\hline $31 \mathrm{PE}$ & SCN & * & * & SCN & * \\
\hline $32 \mathrm{PE}$ & * & SCN & * & * & * \\
\hline $33 \mathrm{PE}$ & SCN & SCN & * & * & * \\
\hline $34 \mathrm{PE}$ & * & * & * & * & * \\
\hline $35 \mathrm{PE}$ & * & * & * & * & * \\
\hline $36 \mathrm{PE}$ & SCN & SCN & * & SCN & * \\
\hline $37 \mathrm{PE}$ & SCN & $S C N$ & * & P. aeruginosa & * \\
\hline $38 \mathrm{PE}$ & SCN & SCN & * & SCN & * \\
\hline $39 \mathrm{PE}$ & * & * & * & Acinetobacter & * \\
\hline $40 \mathrm{PE}$ & SCN & SCN & * & $S C N$ & SCN \\
\hline $41 \mathrm{PE}$ & SCN & SCN & * & SCN & SCN \\
\hline $42 \mathrm{PE}$ & SCN & SCN & $S C N$ & SCN & SCN \\
\hline $43 \mathrm{PE}$ & SCN & SCN & $S C N$ & SCN & SCN \\
\hline
\end{tabular}

LEGENDA: M3: Antes da entrega do brinquedo à criança. M5: Após o processo de higienização do brinquedo. SCN: Stafilococcus coagulase negativa

$P$. aeruginosa: Pseudomonas aeruginosa

M4: Imediatamente após o término da brincadeira.

* Ausência de crescimento bacteriano

S.aureus: Stafilococcus aureus

PE: Pré-escolar 
Tabela 9 - Descrição das bactérias isoladas nas amostras das mãos e dos brinquedos das crianças em idade pré-escolar. Bauru, 2009. (Continuação).

\begin{tabular}{|c|c|c|c|c|c|}
\hline \multicolumn{6}{|c|}{ BACTÉRIAS ISOLADAS } \\
\hline AMOSTRA & MÃO DIREITA & $\begin{array}{c}\text { MÃO } \\
\text { ESQUERDA }\end{array}$ & M3 & M4 & M5 \\
\hline $44 \mathrm{PE}$ & SCN & * & * & SCN & * \\
\hline $45 \mathrm{PE}$ & $S C N$ & * & * & SCN & $S C N$ \\
\hline $46 \mathrm{PE}$ & $S C N$ & SCN & * & SCN & $S C N$ \\
\hline 47 PE & SCN & SCN & * & SCN & $S C N$ \\
\hline $48 \mathrm{PE}$ & SCN & SCN & * & * & * \\
\hline $49 \mathrm{PE}$ & $S C N$ & SCN & * & SCN & $S C N$ \\
\hline $50 \mathrm{PE}$ & * & SCN & * & $*$ & SCN \\
\hline $51 \mathrm{PE}$ & SCN & SCN & * & SCN & $S C N$ \\
\hline $52 \mathrm{PE}$ & $S C N$ & SCN & SCN & SCN & $S C N$ \\
\hline $53 \mathrm{PE}$ & $S C N$ & SCN & * & SCN & $S C N$ \\
\hline $54 \mathrm{PE}$ & * & * & * & SCN & $S C N$ \\
\hline $55 \mathrm{PE}$ & SCN & SCN & SCN & SCN & $S C N$ \\
\hline $56 \mathrm{PE}$ & $S C N$ & SCN & * & SCN & $S C N$ \\
\hline $57 \mathrm{PE}$ & $S C N$ & SCN & * & SCN & * \\
\hline $58 \mathrm{PE}$ & * & * & * & * & * \\
\hline $59 \mathrm{PE}$ & * & SCN & * & SCN & * \\
\hline $60 \mathrm{PE}$ & $S C N$ & SCN & * & * & * \\
\hline $61 \mathrm{PE}$ & $S C N$ & $S C N$ & * & * & * \\
\hline $62 \mathrm{PE}$ & SCN & * & * & * & * \\
\hline $63 \mathrm{PE}$ & SCN & SCN & * & * & * \\
\hline $64 \mathrm{PE}$ & SCN & SCN & * & * & * \\
\hline $65 \mathrm{PE}$ & * & * & * & * & * \\
\hline $66 \mathrm{PE}$ & SCN & SCN & * & * & * \\
\hline $67 \mathrm{PE}$ & SCN & SCN & * & * & * \\
\hline $68 \mathrm{PE}$ & * & SCN & * & SCN & * \\
\hline $69 \mathrm{PE}$ & $S C N$ & SCN & * & * & * \\
\hline $70 \mathrm{PE}$ & SCN & SCN & SCN & SCN & * \\
\hline $71 \mathrm{PE}$ & $S C N$ & SCN & SCN & SCN & * \\
\hline $72 \mathrm{PE}$ & * & * & $*$ & * & * \\
\hline $73 \mathrm{PE}$ & $S C N$ & SCN & * & SCN & * \\
\hline $74 \mathrm{PE}$ & SCN & SCN & * & SCN & * \\
\hline $75 \mathrm{PE}$ & SCN & SCN & * & SCN & * \\
\hline $76 \mathrm{PE}$ & * & * & * & * & * \\
\hline $77 \mathrm{PE}$ & * & * & * & * & * \\
\hline $78 \mathrm{PE}$ & * & * & * & * & * \\
\hline $79 \mathrm{PE}$ & * & * & * & * & * \\
\hline $80 \mathrm{PE}$ & * & * & * & * & * \\
\hline $81 \mathrm{PE}$ & $S C N$ & Acinetobacter & * & SCN & * \\
\hline $82 \mathrm{PE}$ & SCN & * & * & * & $S C N$ \\
\hline $83 \mathrm{PE}$ & * & * & * & * & * \\
\hline $84 \mathrm{PE}$ & SCN & SCN & * & SCN & * \\
\hline $85 \mathrm{PE}$ & * & * & * & * & * \\
\hline $86 \mathrm{PE}$ & * & * & * & * & * \\
\hline $87 \mathrm{PE}$ & * & * & * & * & * \\
\hline $88 \mathrm{PE}$ & * & * & * & * & * \\
\hline $89 \mathrm{PE}$ & SCN & SCN & SCN & * & * \\
\hline $90 \mathrm{PE}$ & $S C N$ & SCN & SCN & SCN & $S C N$ \\
\hline
\end{tabular}

LEGENDA: M3: Antes da entrega do brinquedo à criança. M5: Após o processo de higienização do brinquedo. SCN: Stafilococcus coagulase negativa $P$. aeruginosa: Pseudomonas aeruginosa
M4: Imediatamente após o término da brincadeira.

* Ausência de crescimento bacteriano

S.aureus: Stafilococcus aureus 
A Tabela 10 mostra a descrição dos antibiogramas das bactérias isoladas nas mãos e nos brinquedos do pré-escolar perfazendo um total de 39 amostras.

Para a mão direita, a Tabela 10 apresenta 15 amostras com Stafilococcus coagulase negativa - Oxacilina Resistente e 21 amostras com Stafilococcus coagulase negativa - Oxacilina Sensível.

A Tabela 10 mostra que, em relação à mão esquerda, há uma amostra com Stafilococcus aureus - Oxacilina Sensível e Pseudomonas aeruginosa Ceftazidima e Imipenem Sensível, 16 amostras com Stafilococcus coagulase negativa - Oxacilina Sensível e 16 amostras com Stafilococcus coagulase negativa - Oxacilina Resistente.

Para o M3, momento antes da brincadeira, a Tabela 10 mostra que há oito amostras com crescimento de Stafilococcus coagulase negativa sendo que todas as amostras apresentam o resultado Sensível à Oxacilina.Enquanto para M4, momento imediato a brincadeira há 17 Stafilococcus coagulase negativa Oxacilina Sensível, 17 Stafilococcus coagulase negativa - Oxacilina Resistente e uma Pseudomona aeruginosa - Ceftazidima e Imipenem Sensível. Em M5, momento depois da higienização, há 14 Stafilococcus coagulase negativa Oxacilina Sensível e cinco Stafilococcus coagulase negativa - Oxacilina Resistente.

Essa Tabela também apresenta algumas amostras com o mesmo crescimento bacteriano, porém com um diferente resultado no antibiograma como as amostras: 
$\checkmark$ 1PE com Stafilococcus coagulase negativa na mão direita e em M4, porém com antibiograma diferente sendo para a mão direita Stafilococcus coagulase negativa - Oxacilina Resistente e para o M4 Stafilococcus coagulase negativa - Oxacilina Sensível,

$\checkmark$ 31PE com Stafilococcus coagulase negativa - Oxacilina Sensível na mão direita e Stafilococcus coagulase negativa - Oxacilina Resistente em M4,

$\checkmark$ 40PE com Stafilococcus coagulase negativa - Oxacilina Sensível na mão direita e esquerda e Stafilococcus coagulase negativa - Oxacilina Resistente em M4,

$\checkmark$ 43PE com Stafilococcus coagulase negativa - Oxacilina Resistente nas duas mãos e Stafilococcus coagulase negativa - Oxacilina Sensível em M3,

$\checkmark$ 45PE com resultado Stafilococcus coagulase negativa - Oxacilina Resistente na mão direita e em M4 e Stafilococcus coagulase negativa Oxacilina Sensível em M5,

$\checkmark$ 49PE com Stafilococcus coagulase negativa - Oxacilina Resistente nas mãos e Stafilococcus coagulase negativa - Oxacilina Sensível em M4,

$\checkmark$ 51PE com Stafilococcus coagulase negativa - Oxacilina Resistente na mão direita e esquerda e Stafilococcus coagulase negativa - Oxacilina Sensível em M5.

Há também representado na Tabela 10 as amostras 52PE, 55PE e 90PE onde apresentam Stafilococcus coagulase negativa - Oxacilina Sensível nas duas mãos e em todos os momentos de coleta de swab. 
Tabela 10 - Descrição dos antibiogramas das bactérias isoladas nas mãos do pré-escolar e nos momentos de coleta de swab no brinquedo. Bauru, 2009.

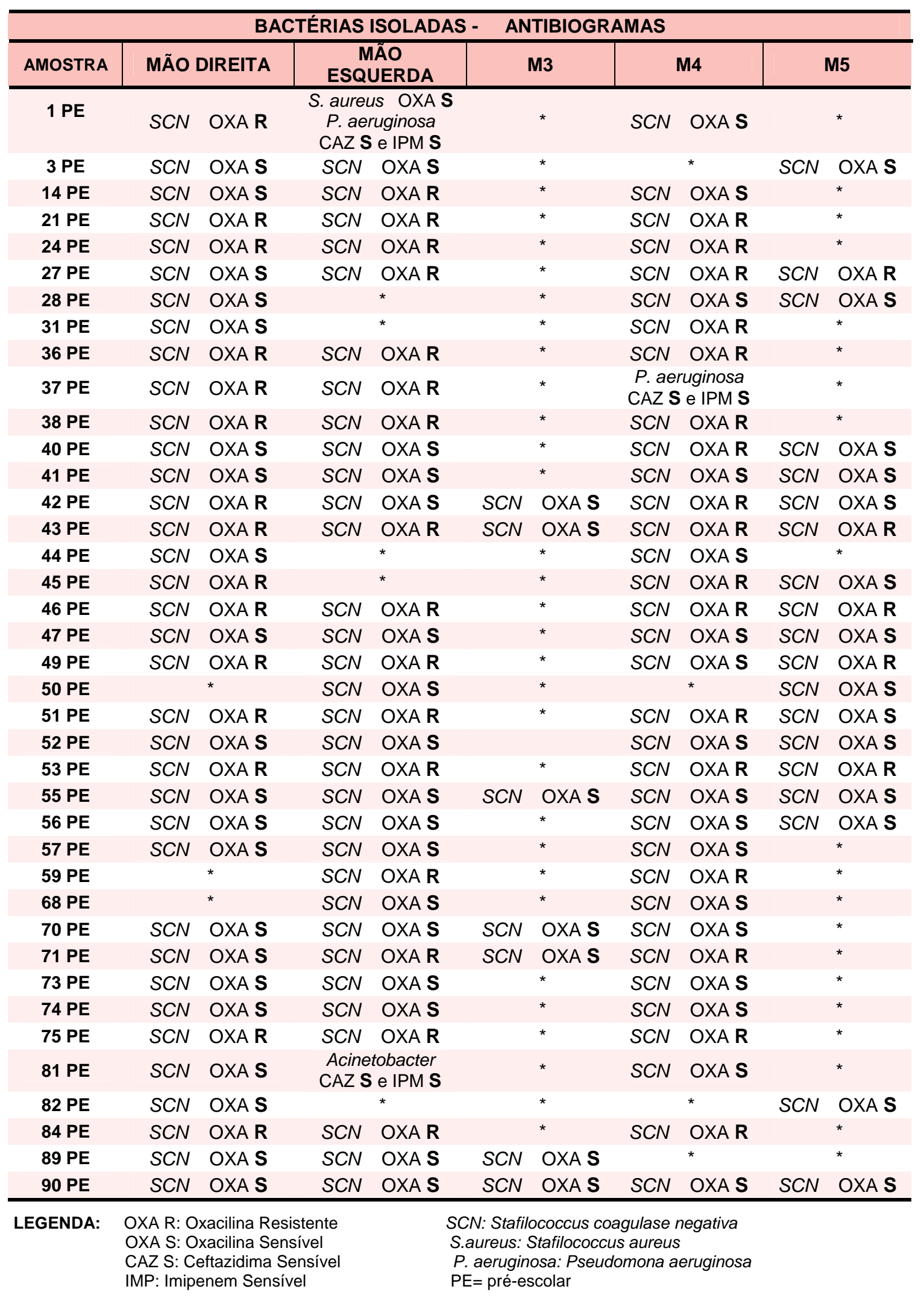


A Tabela 11 mostra que das 90 amostras de coletas das mãos dos escolares, há 75 amostras com crescimento bacteriano, sendo 70 amostras para a mão direita e 62 amostras para a mão esquerda.

Essa Tabela apresenta o crescimento bacteriano de Stafilococcus coagulase negativa em 64 amostras, Pseudomonas aeruginosa em três amostras, Stafilococcus aureus em quatro amostras e Acinetobacter em duas amostras, observando ainda que dentre essas quatro amostras há algumas que apresentaram mais de um tipo de bactéria na mão direita, como as amostras:

$\checkmark \quad 4 \mathrm{E}$ e 18E com Stafilococcus coagulase negativa e Pseudomonas aeruginosa,

$\checkmark$ 47E e 48E com Stafilococcus coagulase negativa e Acinetobacter.

Em relação à mão esquerda, a Tabela 11 mostra o crescimento bacteriano de Stafilococcus coagulase negativa em 55 amostras, Stafilococcus aureus em cinco amostras, Pseudomonas aeruginosa em uma amostra e Escheirichia coli em uma amostra.

Essa Tabela ilustra também as amostras coletadas nos brinquedos sendo que para o momento antes da brincadeira (M3) há Stafilococcus coagulase negativa em sete amostras, para o momento imediato após a brincadeira (M4) há Stafilococcus coagulase negativa em 31 amostras e Stafilococcus aureus em uma amostra e para as amostras do M5, o momento depois do processo de higienização há Stafilococcus coagulase negativa em 17 amostras e Acinetobacter em uma amostra. 
A Tabela 11 mostra ainda que há quatro amostras (5E, 49E, 54E e 61E) com crescimento bacteriano de Stafilococcus coagulase negativa em M3 que apresentam também Stafilococcus coagulase negativa em M4. E as amostras 49E e a 54E que apresentam Stafilococcus coagulase negativa em todos os momentos de coleta de swab.

Há também, demonstrado na Tabela 11, amostras com crescimento bacteriano apenas nas amostras pesquisadas das mãos e ausência de bactérias em todos os outros momentos de coleta.

No momento depois do processo de higienização com álcool 70\% (M5), há 17 amostras com crescimento bacteriano onde duas dessas amostras, 65E e 67E, apresentaram crescimento bacteriano apenas nas mãos e a amostra 89E que apresentou crescimento bacteriano apenas nesse momento de coleta.

A Tabela 11 apresenta também amostras com crescimento bacteriano em todos os momentos de coletas, como as amostras 49E e 54E e amostras com ausência de crescimento bacteriano em todos os momentos de coleta, sendo as amostras: 2E, 9E, 30E, 40E, 42E, 81E, 83E, 84E, 86E, 87E, 88E e 90E. 
Tabela 11 - Descrição das bactérias isoladas nas amostras das mãos e dos brinquedos das crianças em idade escolar. Bauru, 2009.

\begin{tabular}{|c|c|c|c|c|c|}
\hline \multicolumn{6}{|c|}{ BACTÉRIAS ISOLADAS } \\
\hline AMOSTRA & MÃO DIREITA & $\begin{array}{c}\text { MÃO } \\
\text { ESQUERDA } \\
\end{array}$ & M3 & M4 & M5 \\
\hline $1 \mathrm{E}$ & SCN & * & * & * & * \\
\hline $2 \mathrm{E}$ & * & * & * & * & * \\
\hline $3 \mathrm{E}$ & $\mathrm{SCN}$ & * & * & * & * \\
\hline $4 \mathrm{E}$ & $S C N / P$. aeruginosa & SCN & * & * & * \\
\hline $5 \mathrm{E}$ & SCN & SCN & $\mathrm{SCN}$ & SCN & * \\
\hline $6 \mathrm{E}$ & SCN & * & * & * & * \\
\hline $7 \mathrm{E}$ & SCN & SCN & * & SCN & * \\
\hline $8 \mathrm{E}$ & S. aureus & S. aureus & * & * & * \\
\hline $9 \mathrm{E}$ & * & * & * & * & * \\
\hline $10 \mathrm{E}$ & $S C N$ & $S C N$ & * & * & * \\
\hline $11 \mathrm{E}$ & * & SCN & * & SCN & * \\
\hline $12 \mathrm{E}$ & SCN & SCN & * & * & * \\
\hline $13 \mathrm{E}$ & SCN & SCN & * & * & * \\
\hline $14 \mathrm{E}$ & S. aureus & P. aeruginosa & * & * & * \\
\hline $15 \mathrm{E}$ & $\mathrm{SCN}$ & S. aureus & * & * & * \\
\hline $16 \mathrm{E}$ & P. aeruginosa & * & * & * & * \\
\hline $17 \mathrm{E}$ & SCN & SCN & * & * & * \\
\hline $18 \mathrm{E}$ & $S C N / P$. aeruginosa & SCN & * & SCN & * \\
\hline $19 \mathrm{E}$ & SCN & SCN & * & * & * \\
\hline $20 \mathrm{E}$ & SCN & $\mathrm{SCN}$ & * & * & * \\
\hline $21 \mathrm{E}$ & SCN & SCN & * & * & * \\
\hline $22 \mathrm{E}$ & $\mathrm{SCN}$ & SCN & * & * & * \\
\hline $23 \mathrm{E}$ & SCN & SCN & * & * & * \\
\hline $24 \mathrm{E}$ & SCN & SCN & * & * & * \\
\hline $25 \mathrm{E}$ & $\mathrm{SCN}$ & SCN & * & * & * \\
\hline $26 \mathrm{E}$ & $\mathrm{SCN}$ & SCN & * & * & * \\
\hline $27 \mathrm{E}$ & SCN & S. aureus & * & * & * \\
\hline $28 \mathrm{E}$ & SCN & SCN & * & * & * \\
\hline $29 \mathrm{E}$ & $S C N$ & SCN & * & * & * \\
\hline $30 \mathrm{E}$ & * & * & * & * & * \\
\hline $31 \mathrm{E}$ & * & SCN & * & * & * \\
\hline $32 \mathrm{E}$ & SCN & SCN & * & * & * \\
\hline $33 \mathrm{E}$ & SCN & $S C N$ & * & $S C N$ & * \\
\hline $34 \mathrm{E}$ & S. aureus & * & * & * & * \\
\hline $35 \mathrm{E}$ & $S C N$ & SCN & * & * & * \\
\hline $36 \mathrm{E}$ & SCN & SCN & * & SCN & * \\
\hline $37 \mathrm{E}$ & SCN & SCN & $S C N$ & * & * \\
\hline $38 \mathrm{E}$ & * & SCN & * & SCN & * \\
\hline $39 \mathrm{E}$ & S. aureus & S. aureus & * & S. aureus & * \\
\hline $40 \mathrm{E}$ & * & * & * & * & * \\
\hline $41 \mathrm{E}$ & * & * & * & SCN & * \\
\hline $42 \mathrm{E}$ & * & * & * & * & * \\
\hline $43 \mathrm{E}$ & SCN & * & * & * & * \\
\hline $44 \mathrm{E}$ & SCN & $S C N$ & * & $S C N$ & $S C N$ \\
\hline
\end{tabular}

LEGENDA: M3: Antes da entrega do brinquedo à criança. M4: Imediatamente após o término da brincadeira da criança. M5: Após o processo de higienização do brinquedo utilizado na brincadeira

* Ausência de crescimento de bactéria SCN: Stafilococcus coagulase negativa

$\begin{array}{ll}\text { S.aureus: Stafilococcus aureus } & \text { P. aeruginosa: Pseudomonas aeruginosa }\end{array}$

E. coli: Escheirichia coli E: Escolar 
Tabela 11 - Descrição das bactérias isoladas nas amostras das mãos e dos brinquedos das crianças em idade escolar. Bauru, 2009. (Continuação).

\begin{tabular}{|c|c|c|c|c|c|}
\hline \multicolumn{6}{|c|}{ BACTÉRIAS ISOLADAS } \\
\hline AMOSTRA & MÃO DIREITA & MÃO ESQUERDA & M3 & M4 & M5 \\
\hline $45 \mathrm{E}$ & SCN & E. coli & * & * & * \\
\hline $46 \mathrm{E}$ & * & S. aureus & * & * & * \\
\hline $47 \mathrm{E}$ & SCN / Acinetobacter & SCN & * & SCN & SCN \\
\hline $48 \mathrm{E}$ & SCN / Acinetobacter & SCN & * & SCN & SCN / Acinetobacter \\
\hline $49 \mathrm{E}$ & SCN & SCN / Acinetobacter & SCN & SCN & SCN \\
\hline $50 \mathrm{E}$ & * & SCN & * & SCN & * \\
\hline $51 \mathrm{E}$ & SCN & SCN & * & SCN & SCN \\
\hline $52 \mathrm{E}$ & SCN & SCN & * & SCN & SCN \\
\hline $53 \mathrm{E}$ & SCN & SCN & * & SCN & * \\
\hline $54 \mathrm{E}$ & SCN & SCN & SCN & SCN & SCN \\
\hline $55 \mathrm{E}$ & SCN & SCN & * & SCN & * \\
\hline $56 \mathrm{E}$ & SCN & SCN & * & SCN & SCN \\
\hline $57 \mathrm{E}$ & SCN & * & * & SCN & SCN \\
\hline $58 \mathrm{E}$ & SCN & SCN & * & $S C N$ & SCN \\
\hline $59 \mathrm{E}$ & SCN & SCN & * & SCN & * \\
\hline $60 \mathrm{E}$ & SCN & SCN & * & SCN & SCN \\
\hline $61 \mathrm{E}$ & SCN & $S C N$ & $S C N$ & $S C N$ & * \\
\hline $62 \mathrm{E}$ & * & SCN & * & * & * \\
\hline $63 \mathrm{E}$ & SCN & SCN & * & SCN & * \\
\hline $64 \mathrm{E}$ & SCN & * & * & * & * \\
\hline $65 \mathrm{E}$ & SCN & * & * & * & SCN \\
\hline $66 \mathrm{E}$ & SCN & * & * & SCN & SCN \\
\hline $67 \mathrm{E}$ & * & * & * & * & SCN \\
\hline $68 \mathrm{E}$ & SCN & SCN & * & * & * \\
\hline $69 \mathrm{E}$ & SCN & SCN & * & * & * \\
\hline $70 \mathrm{E}$ & SCN & SCN & * & * & * \\
\hline $71 \mathrm{E}$ & SCN & SCN / Acinetobacter & * & * & SCN \\
\hline $72 \mathrm{E}$ & SCN & SCN & * & * & * \\
\hline $73 \mathrm{E}$ & SCN & SCN & * & * & * \\
\hline $74 \mathrm{E}$ & SCN & * & * & * & * \\
\hline $75 \mathrm{E}$ & SCN & SCN & * & * & * \\
\hline $76 \mathrm{E}$ & SCN & SCN & * & * & * \\
\hline $77 \mathrm{E}$ & SCN & * & * & SCN & * \\
\hline $78 \mathrm{E}$ & SCN & SCN & * & $S C N$ & * \\
\hline $79 \mathrm{E}$ & SCN & * & SCN & * & SCN \\
\hline $80 \mathrm{E}$ & SCN & SCN & * & SCN & * \\
\hline $81 \mathrm{E}$ & * & * & * & * & * \\
\hline $82 \mathrm{E}$ & SCN & SCN & SCN & SCN & * \\
\hline $83 \mathrm{E}$ & * & * & * & * & * \\
\hline $84 \mathrm{E}$ & * & * & * & * & * \\
\hline $85 \mathrm{E}$ & SCN & SCN & * & $S C N$ & * \\
\hline $86 \mathrm{E}$ & * & * & * & * & * \\
\hline $87 \mathrm{E}$ & * & * & * & * & * \\
\hline $88 \mathrm{E}$ & * & * & * & * & * \\
\hline $89 \mathrm{E}$ & * & * & * & * & SCN \\
\hline $90 \mathrm{E}$ & * & * & * & * & * \\
\hline
\end{tabular}


Na Tabela 12, observamos que a mão direita apresenta 22 amostras com presença de Stafilococcus coagulase negativa - Oxacilina Sensível e nove amostras com presença de Stafilococcus coagulase negativa - Oxacilina Resistente, uma amostra com Pseudomonas aeruginosa - Ceftazidima Sensível e Imipenem Sensível, um Stafilococcus aureus - Oxacilina Sensível e duas bactérias Acinetobacter - Ceftazidima Sensível e Imipenem Sensível.

Para mão esquerda, a Tabela 12 mostra 22 amostras com presença de Stafilococcus coagulase negativa - Oxacilina Sensível, um Stafilococcus aureus - Oxacilina Sensível, um Acinetobacter - Ceftazidima Sensível e Imipenem Sensível e sete amostras com presença de Stafilococcus coagulase negativa Oxacilina Resistente.

Para o M3, momento antes da brincadeira, a Tabela 12 apresenta três amostras com Stafilococcus coagulase negativa - Oxacilina Resistente e quatro amostras com Stafilococcus coagulase negativa - Oxacilina Sensível. Para o M4, momento imediato após a brincadeira, a Tabela 12 apresenta 10 amostras com Stafilococcus coagulase negativa - Oxacilina Resistente, 20 amostras com Stafilococcus coagulase negativa - Oxacilina Sensível e uma amostra com Stafilococcus aureus - Oxacilina Sensível.

A Tabela 12 mostra que em M5, momento depois da higiene do brinquedo, há 12 amostras com Stafilococcus coagulase negativa - Oxacilina Sensível, três amostras com Stafilococcus coagulase negativa - Oxacilina Resistente e uma amostra com Stafilococcus coagulase negativa - Oxacilina Sensível e Acinetobacter - Ceftazidima Sensível/Imipenem Sensível. 
Essa Tabela apresenta algumas amostras com um determinado crescimento bacteriano e de antibiograma apenas nas amostras das mãos, tendo resultados diferentes nas amostras dos momentos de coleta no brinquedo, sendo as amostras:

$\checkmark 5 \mathrm{E}$ com Stafilococcus coagulase negativa - Oxacilina Sensível nas duas mãos e Stafilococcus coagulase negativa Oxacilina - Resistente em M3 e M4,

$\checkmark$ 18E com Stafilococcus coagulase negativa - Oxacilina Sensível e Pseudomonas aeruginosa - Ceftazidima Sensível/Imipenem Sensível apenas na mão direita,

$\checkmark$ 47E com Stafilococcus coagulase negativa - Oxacilina Sensível e Acinetobacter - Ceftazidima Sensível/Imipenem Sensível apenas na mão direita,

49E com Stafilococcus coagulase negativa - Oxacilina Sensível e Acinetobacter - Ceftazidima Sensível/Imipenem Sensível apenas na mão esquerda,

71E com Stafilococcus coagulase negativa - Oxacilina Resistente e Acinetobacter - Ceftazidima Sensível/Imipenem Sensível apenas na mão esquerda.

Apenas uma amostra a 54E apresentou Stafilococcus coagulase negativa - Oxacilina Sensível em todos os momentos de coletas. 
Tabela 12 - Descrição dos antibiogramas das bactérias isoladas nas mãos do escolar e nos momentos de coleta de swab no brinquedo. Bauru, 2009.

\begin{tabular}{|c|c|c|c|c|c|c|c|c|c|c|}
\hline \multicolumn{11}{|c|}{ BACTÉRIAS ISOLADAS - ANTIBIOGRAMAS } \\
\hline \multirow{2}{*}{$\frac{\text { AMOSTRA }}{5 \mathrm{E}}$} & \multicolumn{2}{|c|}{ MÃO DIREITA } & \multicolumn{2}{|c|}{ MÃO ESQUERDA } & \multicolumn{2}{|c|}{ M3 } & \multicolumn{2}{|r|}{ M4 } & \multicolumn{2}{|c|}{ M5 } \\
\hline & SCN & OXA S & SCN & OXA S & SCN & OXA R & SCN & OXA R & & * \\
\hline $7 \mathrm{E}$ & $S C N$ & OXA S & SCN & OXA S & & * & $S C N$ & OXA S & & * \\
\hline $11 \mathrm{E}$ & \multicolumn{2}{|r|}{ * } & SCN & OXA S & & * & $S C N$ & OXA S & & * \\
\hline $18 \mathrm{E}$ & \multicolumn{2}{|c|}{$\begin{array}{c}\text { SCN OXA S } P . \\
\text { aeruginosa } \\
\text { CAZ S e IPM S }\end{array}$} & $S C N$ & OXA S & & * & SCN & OXA S & & * \\
\hline $33 \mathrm{E}$ & $S C N$ & OXA R & SCN & OXA S & & * & SCN & OXA R & & * \\
\hline $36 \mathrm{E}$ & SCN & OXA S & SCN & OXA S & & * & $S C N$ & OXA S & & * \\
\hline $37 \mathrm{E}$ & SCN & OXA S & SCN & OXA S & SCN & OXA S & & * & & * \\
\hline $38 \mathrm{E}$ & & * & SCN & OXA S & & * & $S C N$ & OXA S & & * \\
\hline $39 \mathrm{E}$ & \multicolumn{2}{|c|}{ S. aureus OXA S } & \multicolumn{2}{|c|}{ S. aureus OXA S } & & * & \multicolumn{2}{|c|}{$\begin{array}{c}\text { S. aureus OXA } \\
\mathbf{S}\end{array}$} & & * \\
\hline $44 \mathrm{E}$ & $S C N$ & OXA R & SCN & OXA S & & * & SCN & OXA R & SCN & OXA S \\
\hline $47 \mathrm{E}$ & \multicolumn{2}{|c|}{$\begin{array}{l}\text { Acinetobacter } \\
\text { CAZ S e IPM S }\end{array}$} & $S C N$ & OXA S & & * & $S C N$ & OXA S & $S C N$ & OXA S \\
\hline $48 \mathrm{E}$ & \multicolumn{2}{|c|}{$\begin{array}{l}\text { Acinetobacter } \\
\text { CAZ S e IPM S }\end{array}$} & SCN & OXA $\mathbf{S}$ & & * & $S C N$ & OXA S & \multicolumn{2}{|c|}{$\begin{array}{l}\text { Acinetobacter } \\
\text { CAZ S e IPM S }\end{array}$} \\
\hline $49 \mathrm{E}$ & SCN & OXA S & \multicolumn{2}{|c|}{$\begin{array}{l}\text { Acinetobacter } \\
\text { CAZ S e IPM S }\end{array}$} & SCN & OXA S & $S C N$ & OXA S & $S C N$ & OXA S \\
\hline $50 \mathrm{E}$ & \multicolumn{2}{|r|}{ * } & SCN & OXA R & & * & SCN & OXA R & & * \\
\hline $51 \mathrm{E}$ & $S C N$ & OXA S & SCN & OXA S & & * & $S C N$ & OXA S & SCN & OXA S \\
\hline $52 \mathrm{E}$ & $S C N$ & OXA R & SCN & OXA R & & * & SCN & OXA R & $S C N$ & OXA $\mathbf{R}$ \\
\hline $53 \mathrm{E}$ & $S C N$ & OXA R & SCN & OXA S & & * & $S C N$ & OXA S & & * \\
\hline $54 \mathrm{E}$ & $S C N$ & OXA S & SCN & OXA S & $S C N$ & OXA S & $S C N$ & OXA S & $S C N$ & OXA S \\
\hline $55 \mathrm{E}$ & $S C N$ & OXA R & SCN & OXA R & & * & SCN & OXA R & & * \\
\hline $56 \mathrm{E}$ & $S C N$ & OXA R & SCN & OXA R & & * & SCN & OXA R & $S C N$ & OXA $\mathbf{R}$ \\
\hline $57 \mathrm{E}$ & $S C N$ & OXA S & & * & & * & SCN & OXA R & $S C N$ & OXA S \\
\hline $58 \mathrm{E}$ & $S C N$ & OXA S & SCN & OXA S & & * & $S C N$ & OXA S & $S C N$ & OXA S \\
\hline $59 \mathrm{E}$ & $S C N$ & OXA S & SCN & OXA S & & * & $S C N$ & OXA S & & * \\
\hline $60 \mathrm{E}$ & $S C N$ & OXA S & SCN & OXA S & & * & $S C N$ & OXA S & $S C N$ & OXA S \\
\hline $61 \mathrm{E}$ & $S C N$ & OXA S & SCN & OXA S & $S C N$ & OXA S & $S C N$ & OXA S & & * \\
\hline $63 \mathrm{E}$ & $S C N$ & OXA R & SCN & OXA R & & * & SCN & OXA R & & * \\
\hline $65 \mathrm{E}$ & $S C N$ & OXA S & & * & & * & & * & $S C N$ & OXA S \\
\hline $66 \mathrm{E}$ & $S C N$ & OXA S & & * & & * & $S C N$ & OXA S & $S C N$ & OXA S \\
\hline $71 \mathrm{E}$ & SCN & OXA S & $\begin{array}{l}\text { SCN } \\
\text { Acine } \\
\text { CAZ S }\end{array}$ & $\begin{array}{l}\text { OXA R } \\
\text { tobacter } \\
\text { e IPM S }\end{array}$ & & * & & * & $S C N$ & OXA S \\
\hline $77 \mathrm{E}$ & SCN & OXA S & & * & & * & $S C N$ & OXA S & & * \\
\hline $78 \mathrm{E}$ & $S C N$ & OXA S & SCN & OXA S & & * & $S C N$ & OXA S & & * \\
\hline $79 \mathrm{E}$ & $S C N$ & OXA R & & * & SCN & OXA R & & * & $S C N$ & OXA R \\
\hline $80 \mathrm{E}$ & $S C N$ & OXA S & SCN & OXA S & & * & $S C N$ & OXA S & & * \\
\hline $82 \mathrm{E}$ & $S C N$ & OXA R & SCN & OXA R & $S C N$ & OXA R & SCN & OXA R & & * \\
\hline $85 \mathrm{E}$ & SCN & OXA S & SCN & OXA S & & * & SCN & OXA S & & * \\
\hline GENDA: & $\begin{array}{l}\text { OXA R: } \\
\text { OXA S: } \\
\text { CAZ S: C } \\
\text { IMP: Imip }\end{array}$ & $\begin{array}{l}\text { xacilina res } \\
\text { xacilina sen } \\
\text { eftazidima s } \\
\text { enem sensí }\end{array}$ & $\begin{array}{l}\text { ente } \\
\text { vel } \\
\text { sível } \\
\text { I }\end{array}$ & & $\begin{array}{l}\text { ireus: } \\
\text { erugin } \\
\text { escolar }\end{array}$ & $\begin{array}{l}\text { ococcus } \\
\text { Stafiloco } \\
\text { osa: Pse }\end{array}$ & $\begin{array}{l}\text { gulase } r \\
\text { aureus } \\
\text { mona ae }\end{array}$ & $\begin{array}{l}\text { negativa } \\
\text { eruginosa }\end{array}$ & & \\
\hline
\end{tabular}


A Tabela 13 apresenta os resultados do teste de sensibilidade "in vitro" dos produtos de higiene em relação às bactérias isoladas nas amostras do préescolar, tendo como resultado para a mão direita que a clorexidina degermante 2\% tem em média halo de 6,6 mm, a clorexidina alcoólica 2\% média de halo de 6,4 mm, o álcool 70\% média de halo de 1,6 mm e o hipoclorito de Sódio 1\% média de halo de 0,7 mm.

Para as bactérias isoladas na mão esquerda, a média do halo em relação ao produto clorexidina degermante $2 \%$ é de $5,5 \mathrm{~mm}$, o clorexidina alcoólico $2 \%$ de $5,3 \mathrm{~mm}$, o álcool $70 \%$ de $1,0 \mathrm{~mm}$ e a do hipoclorito $1 \%$ é 0,3 $\mathrm{mm}$.

A Tabela 13 mostra que para as bactérias isoladas dos brinquedos antes da brincadeira (M3), as médias dos halos em relação às bactérias isoladas dos produtos clorexidina alcoólico $2 \%$ e clorexidina degermante $2 \%$ são de $6,7 \mathrm{~mm}$, o álcool $70 \%$ tem média de $1,6 \mathrm{~mm}$ e a média do hipoclorito $1 \%$. Para 0 momento imediatamente após a brincadeira (M4), a média do halo para a clorexidina alcoólica $2 \%$ é $6,5 \mathrm{~mm}$, para o clorexidina degermante $2 \%$ é $5,3 \mathrm{~mm}$, para o álcool $70 \%$ é $2,2 \mathrm{~mm}$ e para o hipoclorito $1 \%$ é de $0,5 \mathrm{~mm}$. E para as bactérias isoladas no momento depois da higiene do brinquedo (M5) a média dos halos em relação ao produto clorexidina alcoólica $2 \%$ é de $7,4 \mathrm{~mm}$, clorexidina degermante $2 \%$ é de $6,6 \mathrm{~mm}$, álcool $70 \%$ é de $2,1 \mathrm{~mm}$ e hipoclorito $1 \%$ é de $1 \mathrm{~mm}$. 
A Tabela 13 ilustra ainda que os produtos de higiene clorexidina Alcoólico $2 \%$ e clorexidina degermante $2 \%$ foram os produtos que obtiveram maiores halos formados nas Placas de Petri pesquisadas, sendo o mesmo aferido em milímetros, o que demonstra que a bactéria isolada apresenta sensibilidade em relação ao produto de higiene, seguido do álcool 70\%. A água e o sabão não obtiveram resultado maior que zero, ou seja, não houve formação de halo nas Placas de Petri pesquisadas o que significa resistência da bactéria isolada frente ao produto. 


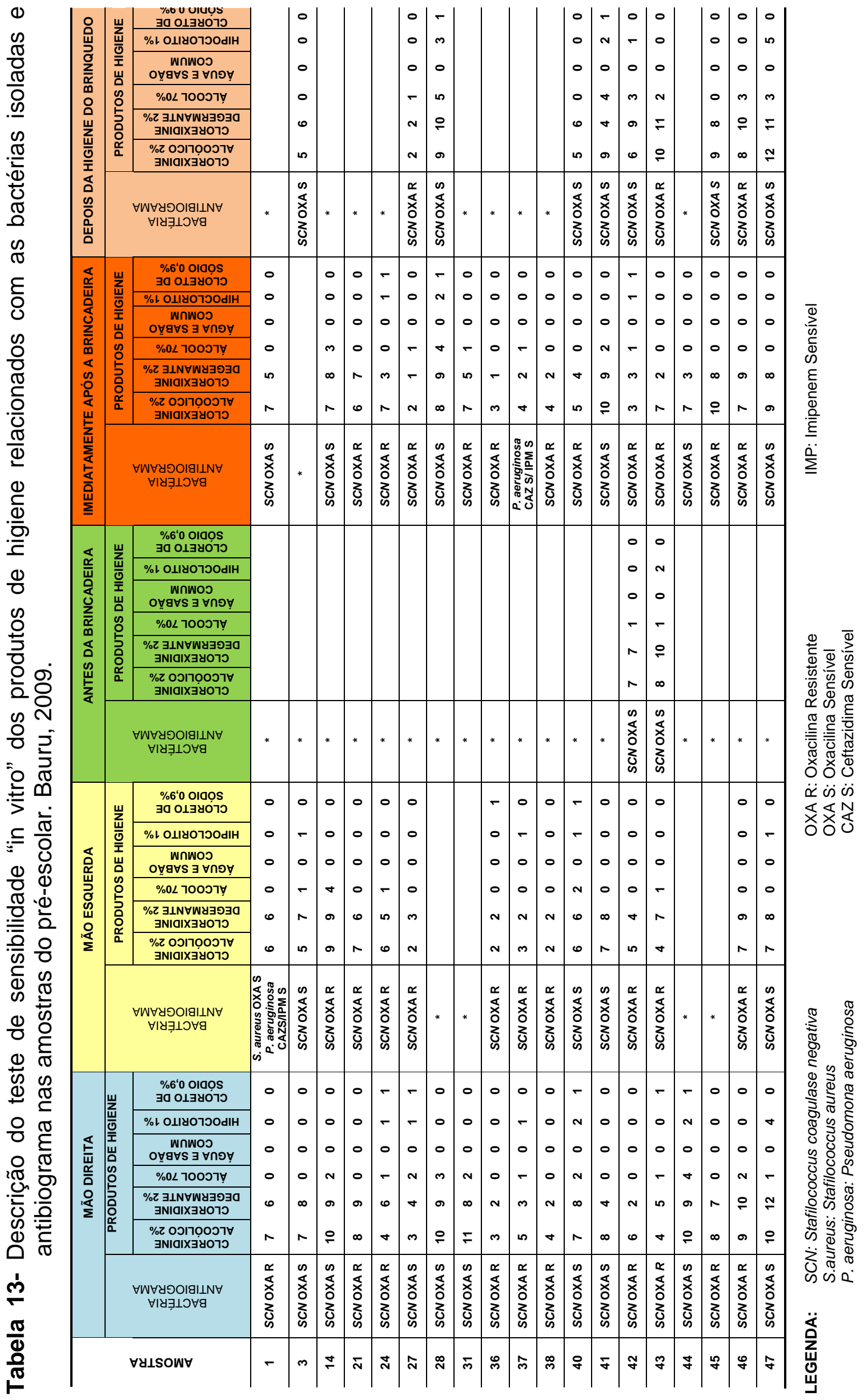




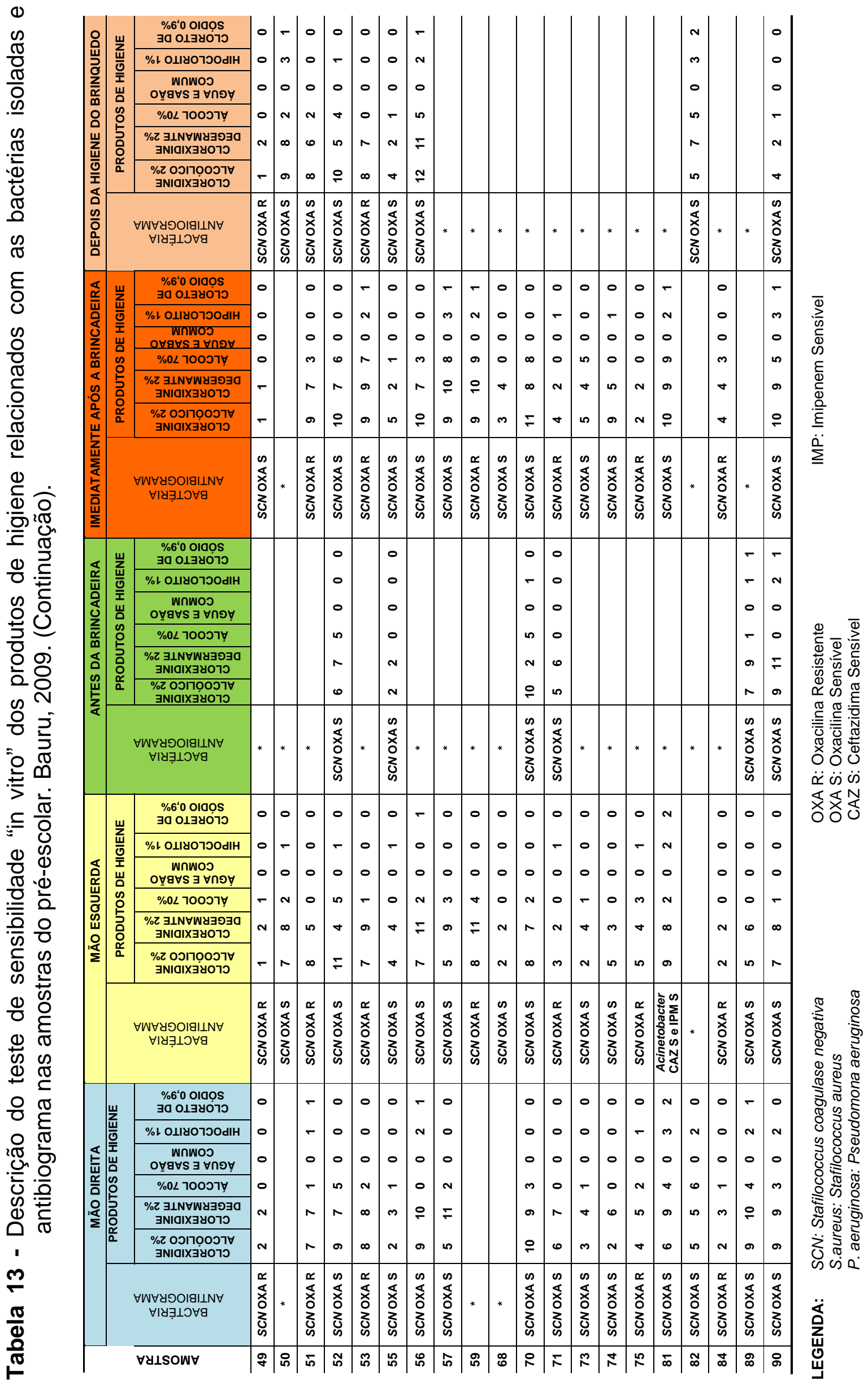


A Tabela 14 mostra os resultados para o teste de sensibilidade "in vitro" dos produtos de higiene em relação às bactérias isoladas do escolar.

Traz nessa Tabela que para a mão direita a média do halo frente ao produto clorexidina alcoólico $2 \%$ é $6,7 \mathrm{~mm}$, da clorexidina degermante $2 \%$ a média é de $6,5 \mathrm{~mm}$, o álcool $70 \%$ tem média de $1,5 \mathrm{~mm}$ e o hipoclorito $1 \%$ média de 0,6mm. Para a mão esquerda, a média do halo do produto clorexidina alcoólica $2 \%$ é de $6,7 \mathrm{~mm}$, do clorexidina degermante $2 \%$ é $6,5 \mathrm{~mm}$, do álcool $70 \%$ a média é $1,8 \mathrm{~mm}$ e do produto hipoclorito $1 \%$ a média é $0,6 \mathrm{~mm}$.

No momento de coleta antes da brincadeira (M3), a Tabela 14 mostra para o produto clorexidina alcoólica $2 \%$ a média do halo é de $6 \mathrm{~mm}$, para 0 clorexidina degermante $2 \%$ a média é de $6,6 \mathrm{~mm}$, para o álcool $70 \%$ é $2,8 \mathrm{~mm}$ e par o produto hipoclorito $1 \%$ a média é $1,3 \mathrm{~mm}$. Para o momento imediato após a brincadeira (M4), a média do halo da clorexidina alcoólica $2 \%$ é 7,4mm, para o clorexidina degermante $2 \%$ é $6,9 \mathrm{~mm}$, para o álcool $70 \%$ é $2,8 \mathrm{~mm}$ e para o produto de higiene hipoclorito $1 \%$ é $0,8 \mathrm{~mm}$.

A Tabela 14 apresenta para o momento depois da higiene do brinquedo (M5) média de halo para a clorexidina alcoólica $2 \%$ de é $7,5 \mathrm{~mm}$, para a clorexidina degermante $2 \%$ média de $6,8 \mathrm{~mm}$, para o álcool $70 \%$ média de 2,7mm e para o hipoclorito 1\% média de 1,3mm. Para a água e sabão houve apenas uma amostra (56 E) com resultado numérico maior que zero, sendo 2 $\mathrm{mm}$.

A caixa de plástico contendo os pinos não apresentou nenhum crescimento bacteriano em todas as amostras realizadas. 


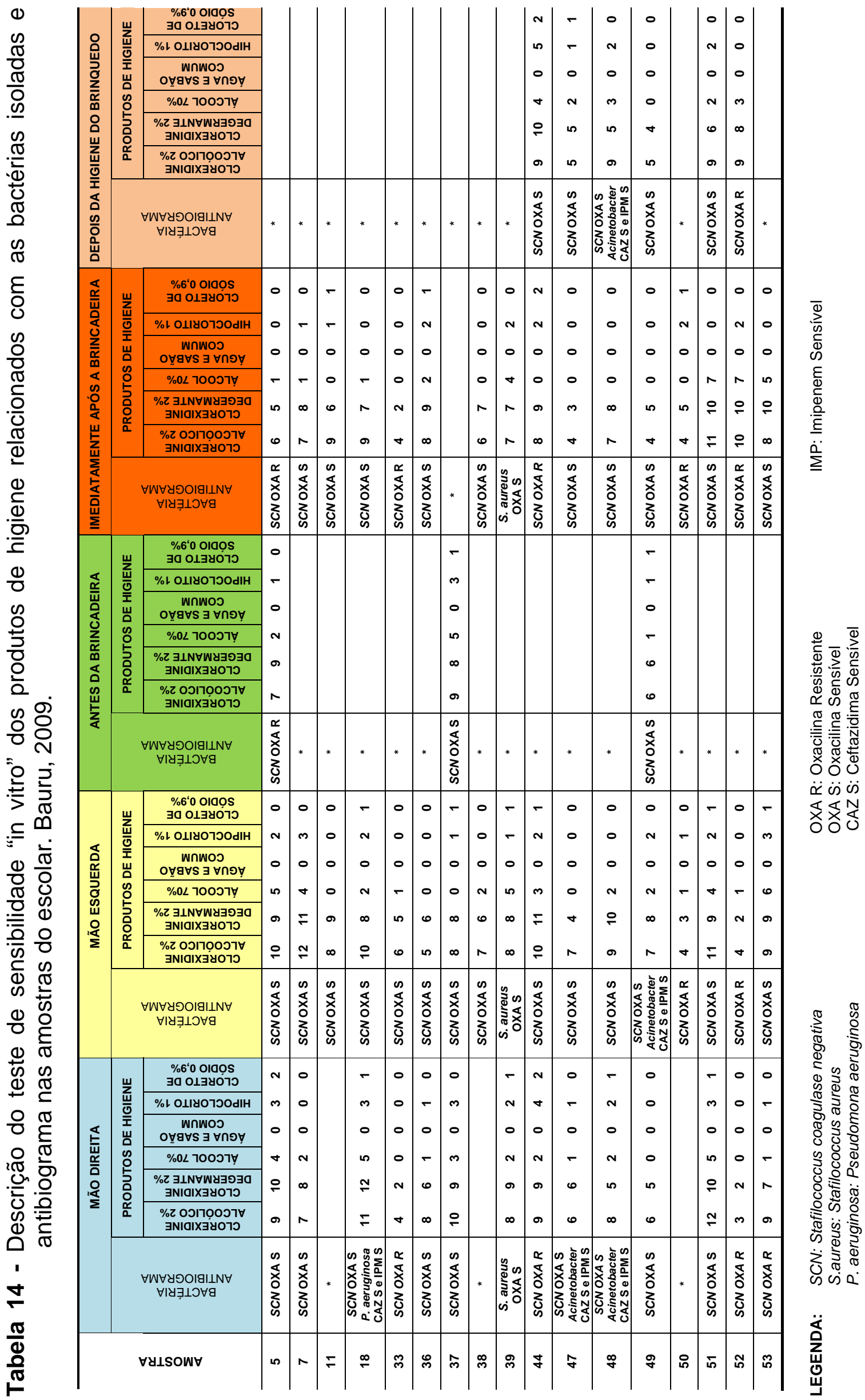




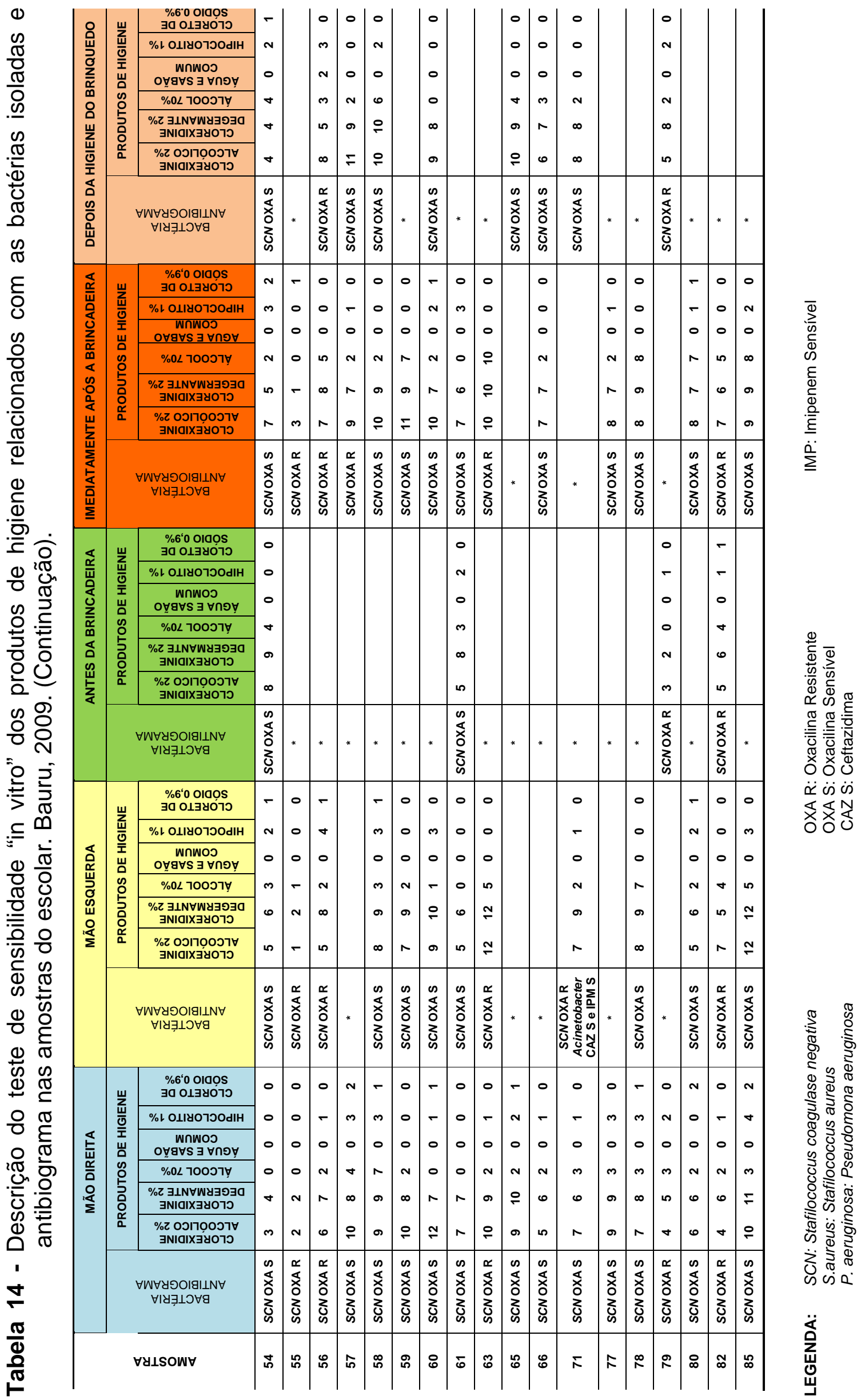


A Tabela 15 ilustra a sensibilidade "in vitro" das bactérias isoladas frente aos produtos de higiene pesquisados, onde há para o produto clorexidina alcoólica 2\% um maior número de amostras com halos maiores que $7 \mathrm{~mm}$, ou seja, as bactérias isoladas apresentaram sensibilidade em relação a esse produto de higiene, perfazendo um total de 149 amostras.

Para a clorexidina degermante $2 \%$, a Tabela 15 também apresenta um número grande de amostras com presença de halos maiores que $7 \mathrm{~mm}$, indicando que as bactérias isoladas também apresentam sensibilidade relacionada a esse produto. Já para o álcool 70\%, apresenta mais amostras com halos medindo entre $1 \mathrm{~mm}$ a $6 \mathrm{~mm}$, indicando que as bactérias isoladas apresentam pouca sensibilidade frente a esse produto de higiene.

Nessa Tabela, também há mostrada a sensibilidade da Água e Sabão comum e hipoclorito 1\%, onde ambos apresentaram um grande número de amostras com ausência de halos nas Placas de Petri que contêm as bactérias isoladas, demonstrado pelo valor $0 \mathrm{~mm}$, o que torna esses produtos indicativos de resistentes às bactérias isoladas. Há um diferencial para o produto Água e Sabão que apresentou em uma amostra um halo de $2 \mathrm{~mm}$.

A Tabela 15 apresenta que o produto Cloreto de Sódio 0,9\%, usado como controle, apresentou algumas amostras com resposta de sensibilidade, sendo 65 amostras com presença de halos com valores entre $1 \mathrm{~mm}$ e $6 \mathrm{~mm}$.

Dos 247 testes de sensibilidade realizados para cada produto de higiene, podemos classificá-los em resistente $(0 \mathrm{~mm})$, pouco sensível $(1 \mathrm{~mm}$ a $6 \mathrm{~mm}$ ) e sensível (7 $\mathrm{mm}$ a $12 \mathrm{~mm})$. 
Tabela 15 - Descrição da sensibilidade "in vitro" das bactérias isoladas frente aos produtos de higiene. Bauru, 2009.

\begin{tabular}{|c|c|c|c|c|c|c|}
\hline \multicolumn{7}{|c|}{ PRODUTOS DE HIGIENE } \\
\hline $\begin{array}{l}\text { TAMANHO } \\
\text { DO HALO }\end{array}$ & 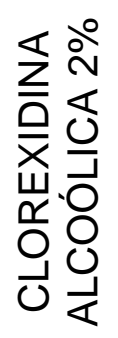 & 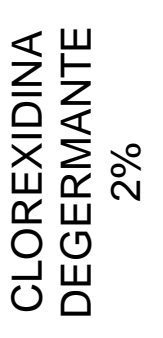 & 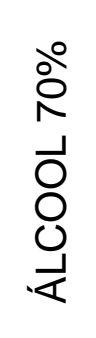 & 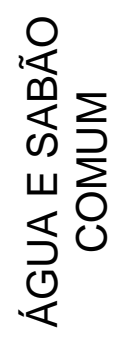 & 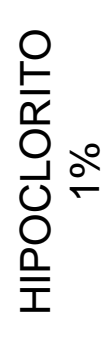 & 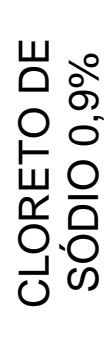 \\
\hline $0 \mathrm{~mm}$ & 0 & 0 & 78 & 246 & 134 & 182 \\
\hline $1 m m-6 m m$ & 98 & 110 & 155 & 1 & 113 & 65 \\
\hline $7 \mathrm{~mm}-12 \mathrm{~mm}$ & 149 & 137 & 14 & 0 & 0 & 0 \\
\hline Total & 247 & 247 & 247 & 247 & 247 & 247 \\
\hline
\end{tabular}

LEGENDA: $0 \mathrm{~mm}$ : resistência

$1 \mathrm{~mm}-6 \mathrm{~mm}$ : pouca sensibilidade

$7 \mathrm{~mm}-12 \mathrm{~mm}$ : sensibilidade 
5. Discussães 


\section{DISCUSSÕES}

As mãos como já se sabe é um dos mais preocupantes veículos de transmissão de microorganismos e a sua higienização se faz necessária principalmente na diminuição de riscos para as crianças internadas em ambiente hospitalar.

Para a faixa etária das crianças incluídas neste estudo, há uma discreta diferença nas amostras com presença de crescimento bacteriano, sendo maior nas amostras dos escolares. Sugere-se que a fase de aprendizagem das crianças pré-escolares e escolares não interferiu no fato da contaminação de suas mãos. Isso nos remete a uma questão de educação em saúde, uma vez que as crianças necessitam da orientação e da supervisão dos adultos para a aprendizagem de algumas ações, entre elas a lavagem das mãos. O resultado encontrado no estudo nos sugere que a incorporação desse hábito não está presente também para os adultos, consequentemente não sendo estendida para as crianças ${ }^{(76)}$.

Essa questão pode ser confirmada por meio de estudos que se referem à necessidade de inclusão de rotinas e padronizações para a lavagem das mãos, pois essa ação ainda não faz parte das atividades rotineiras até mesmo dos profissionais de saúde ${ }^{(48,49,77,78)}$. Estudo refere que os profissionais no ambiente hospitalar não demonstraram o hábito de lavar as mãos antes e após os cuidados, nem mesmo com as crianças portadoras de diarreia aguda, em especial os enfermeiros, mesmo sendo a lavagem das mãos um assunto comum entre os ambientes que prestam cuidados às crianças ${ }^{(49)}$. 
Ainda sugerindo a influência dos adultos na falha dos ensinamentos às crianças em relação à questão da higiene das mãos, a literatura traz um estudo que se refere às condições de higiene das mãos de pessoas manipuladoras de alimentos em refeitório onde encontrou que 50\% dos manipuladores apresentavam condições de higiene insatisfatória para tal prática ${ }^{(46)}$.

Outro estudo, analisando os conhecimentos e práticas de educadoras e trabalhadoras de creches, concluiu que o ítem lavagem das mãos com a intenção da não transmissão de infecção é pouco conhecido por essas educadoras. Esse resultado nos leva a refletir sobre a falta de hábito na lavagem das mãos de educadores, que são pessoas que estão diretamente ligadas às crianças, até mesmo como modelo, e que estão apresentando atitudes que serão consequentemente absorvidas pelas mesmas ${ }^{(77)}$.

Assim como as brincadeiras como: pular corda, brincar de escondeesconde e ciranda normalmente são estimuladas pelos adultos, os princípios básicos de higiene também deveriam ter esse estímulo. A conduta do adulto também é imitada pela criança. Ela poderá crescer com uma boa educação relacionada aos hábitos de higiene se aprendê-la com os seus pais e os educadores que, de alguma forma, estabeleceram estes valores para essa criança. Uma conduta natural do ser humano, que compreende além do respeito, amor, paciência e carinho. Para que a criança seja bem educada em higienização e desenvolva bons hábitos, é necessário que ela receba informações e exemplos ${ }^{(79)}$. 
Segundo a literatura ${ }^{(80)}$ por volta dos sete ou oito anos de idade, as crianças passam a racionalizar seus pensamentos e suas crenças, procurando as razões, os porquês dos problemas e dos fatos. Assim, as próprias crianças passam a analisar os padrões de comportamento ensinados pela família e sociedade e surgem as comparações com outras crianças da mesma idade. Estes dois fatos, somados ao crescimento da vida social, diminuem o favoritismo pela importância dos pais e da família como modelos de comportamento para a criança, e aumentam a importância dos amigos e dos professores.

Pórem os achados no presente estudo mostram que houve o predomínio de crescimento bacteriano nas amostras pesquisados das mãos da criança em idade escolar, o que pode corroborar com estudo ${ }^{(81)}$ que apresenta conclusão onde as crianças com idade dos seis aos dez anos não possuíam conhecimento das doenças transmitidas pelas mãos e o procedimento correto da lavagens das mãos. Esse estudo foi realizado com cerca de 300 crianças em escolas infantis onde após conclusão e divulgação houve um feedback dos pais para saberem mais sobre o tema.

Outro dado que nos chama atenção é a indiferença entre o crescimento bacteriano nas mãos pesquisadas, direita e esquerda. Esse resultado nos sugere que é pelo fato de a criança estar adquirindo habilidades motoras, o que vem de encontro com a literatura quando coloca que o ato de brincar na infância é uma ação onde as crianças utilizam as duas mãos, trazendo a questão do refinamento das habilidades motoras, que se inicia na fase pré- 
escolar e atinge seu ápice no início da idade escolar e do ato em si de segurar o brinquedo com mais segurança ${ }^{(80)}$.

Mais um dado importante do presente estudo é sobre a maior frequência de crescimento bacteriano nas amostras das crianças do sexo masculino. Esse resultado apresenta-se de acordo com as características de desenvolvimento da criança, uma vez que os meninos na faixa etária escolar tendem a um comportamento diferente das meninas, em relação aos tipos de brincadeiras que geralmente precisam da questão do toque corporal, do tipo lutas e empurrões e a exploração do ambiente. Inicia-se também a fase de desenvolvimento dos órgãos sexuais do corpo e da formação da autoestima onde as meninas dão mais importância à higiene corporal do que os meninos sugerindo a presença maior de crescimento de bactérias encontrada nas mãos dos meninos ${ }^{(81,82)}$.

Ao comparar os resultados encontrados em relação à identificação das bactérias isoladas nas mãos das crianças neste estudo com o achado em literatura sobre análise das mãos de manipuladores de alimentos ${ }^{(46)}$ e sobre análise da colonização bacteriana nas mãos dos profissionais ${ }^{(78) \text {, }}$ percebemos resultados semelhantes como o crescimento bacteriano de: Stafilococcus coagulase negativa, Stafilococcus aureus, Escheirichia coli, Pseudomona aeruginosa e Acinetobacter. Esses resultados vêm reforçar que as mãos são um veículo na transmissão de microrganismos, consequentemente a técnica da lavagem das mãos é um ato importante no controle da transmissão de microrganismos. 
Apesar dessa semelhança de resultados em diferentes locais de pesquisa, há o agravo das consequências da presença dessas bactérias no ambiente hospitalar, principalmente os que possuem atendimento para crianças, devido ao fato de a imunidade na criança desenvolver-se com a idade e de a queda da imunidade ocorrer com maior facilidade, deixando a criança mais suscetível a quadro de infecções ${ }^{(83)}$.

Um dado que nos chama atenção é do crescimento de Stafilococcus coagulase negativa na maioria das amostras seguido de 13 amostras com Stafilococcus aureus, tanto nas mãos do pré-escolar e do escolar. O resultado encontrado neste estudo difere do estudo com os manipuladores de alimentos onde a bactéria Stafilococcus aureus foi maioria nos achados ${ }^{(46)}$, talvez pelo fato de a análise ter ocorrido nas mãos dos profissionais. A quantidade de amostras com resultado de crescimento de Stafilococcus aureus $(7,22 \%)$ encontrado nesse estudo é um número preocupante, pois esta é uma bactéria patogênica que pode ser encontrada na pele e na região da nasofaringe e está presente em aproximadamente $15 \%$ dos indivíduos ${ }^{(81)}$.

Evidenciando o resultado encontrado neste estudo, onde bactérias de grande importância clínica e epidemiológica foram isoladas, a preocupação com as condições de higiene das mãos e de outros objetos que possam ser considerados veículos devem ser destacadas pensando na oferta de materiais de transmissão, uma vez que são facilmente encontrados, como por exemplo: na secreção nasal que pode conter Stafilococcus coagulase negativo e Stafilococcus aureus; na contaminação das mãos por material fecal relacionado com Escheirichia coli e Klebisiella e as bactérias Não Fermentadoras como 
Pseudomona aeruginosa e Acinetobacter indicando a utilização inadequada de produtos antissépticos ${ }^{(35,46)}$. Essa preocupação ainda é maior relacionada à criança, devido à questão da imaturidade da imunidade e da exploração dos ambientes utilizando as mãos ${ }^{(81-83)}$.

No que se refere às Pseudomonas aeruginosas, cabe a preocupação devido a estudo ${ }^{(65)}$ que levantou a presença de cepas desta bactéria em amostras de sangue, de cateteres venosos e também em amostras de urina. 0 que nos alerta para uma observação mais cautelosa sobre a higiene das mãos das crianças em idade pré-escolar e escolar antes das atividades na brinquedoteca e outras comuns sabendo que as mesmas ainda não possuem conhecimento ou habilidade na higiene corporal, como por exemplo, ao utilizarem o banheiro.

Ao analisar as condições bacteriológicas do brinquedo após a brincadeira, vê-se no presente estudo que houve a predominância da bactéria Stafilococcus coagulase negativa. Esse dado vem corroborar com estudo que relata a prevalência de Stafilococcus coagulase negativa nos brinquedos pesquisados em uma brinquedoteca hospitalar ${ }^{(31)}$ e também com outro estudo realizado com amostras de hemocultura dos bebês em maternidade na cidade de Natal-RN ${ }^{(84)}$.

Outro estudo que vem ao encontro dos achados deste, ao analisar os brinquedos em Unidade de Terapia Intensiva, neonatal concluiu que houve o crescimento microbiano após o contato da criança com o brinquedo. Ressalta ainda que naquela unidade havia processo de orientação aos profissionais e familiares sobre a lavagem das mãos na intenção de prevenir a disseminação 
de microrganismos, porém, não havia um processo de higiene dos brinquedos deixados nos leitos o que sugeriu que os pais e funcionários, apesar de lavar as mãos antes de ter contato com os bebês inaverditamente seguravam os brinquedos contaminados ${ }^{(63)}$.

Outro microrganismo isolado nesse estudo foram as Pseudomonas aeruginosas no brinquedo após a brincadeira tanto do pré-escolar quanto do escolar. Esses dados vêm ao encontro de estudo realizado em Unidade de Oncologia Pediátrica que analisou os brinquedos utilizados pelas crianças concluindo por meio da técnica da biologia molecular que as cepas isoladas das crianças eram as mesmas isoladas nos brinquedos ${ }^{(85)}$.

Outro estudo que corrobora com o presente achado associou surtos de infecções por Pseudomonas aeruginosa multirresistente como adquiridas por meio da transmissão pelos brinquedos compartilhados, comprovados pela análise do DNA bacteriano entre os achados patogênicos dos pacientes, brinquedos e caixa de armazenamento dos brinquedos contendo água ${ }^{(65)}$.

Também foram identificadas bactérias como Acinetobacter no presente estudo, nas amostras do brinquedo após a brincadeira o que acorda com estudo citado anteriormente sobre brinquedos em brinquedoteca hospitalar que também isolou essa bactéria em percentual menor ${ }^{(31)}$.

Em relação ao antibiograma das bactérias isoladas nesse estudo, obteve-se a predominância de Oxacilina Sensível para as bactérias Stafilococcus coagulase negativo e Stafilococcus aureus e obteve-se sensibilidade para Ceftazidima e Imipenem para as bactérias Pseudomonas 
aeruginosas e Acinetobacter. Esse resultado vem ao encontro da ação proposta para esses antibióticos ${ }^{(86)}$ e com estudos que encontraram bactérias sensíveis nas amostras pesquisadas ${ }^{(31,65,84,87)}$.

E ainda em relação aos resultados encontrados no atual estudo, isolaram-se também amostras com Stafilococcus coagulase negativo Resistente à Oxacilina. Esse achado vem corroborar com o estudo realizado com os estetoscópios em setores pediátricos de um hospital onde concluiu que esses equipamentos se apresentavam contaminados com Stafilococcus resistentes em uma minoria ${ }^{(88)}$, assim como o presente estudo.

Esses resultados contrariam a intenção proposta para o antibiótico Oxacilina, levando-nos a uma preocupação em relação às adaptações das bactérias frente aos antibióticos. A literatura traz a acentuada evolução do Staphylococcus aureus e do Staphylococcus coagulase negativa e a sua resistência a múltiplos antibióticos ${ }^{(89)}$. E nos gera a reflexão em torno do uso correto dos antibióticos, assim como em estudos que citam que o uso abusivo de drogas antimicrobianas tem-se constituído em importantes fatores na seleção de amostras multirresistentes e na transferência de genes de resistência ${ }^{(87,89)}$.

Ao analisar os produtos de higiene "in vitro", percebe-se que a clorexidina alcoólica $2 \%$ foi sensível seguida da clorexidina degermante 2\%, frente às bactérias isoladas nas amostras das mãos e dos brinquedos analisados. O presente achado corrobora com estudo sobre a eficácia da clorexidina "in vitro" e "in vivo" em humanos e animais que demonstrou resultado significativo na desinfecção da pele ${ }^{(90)}$ e com outros estudos sobre a 
higiene das superfícies com a clorexidina ${ }^{(91,92,93)}$. Ainda na revisão da literatura, foi encontrado apenas um estudo que utilizou a clorexidina alcoólica 2\% como desinfetante para os brinquedos, porém não esclarece se o mesmo é de uso de rotina ou apenas para o estudo ${ }^{(94)}$.

Isso nos sugere que a restrição do uso da clorexidina alcoólica $2 \%$, que mostrou ser eficaz, e a não utilização desse desinfetante para a higienização de materiais como, por exemplo, o brinquedo, possa ser pelo seu elevado custo, conforme descrito em estudo ${ }^{(92)}$.

Neste estudo foi identificado para o álcool $70 \%$ pouca sensibilidade frente às bactérias isoladas como: Stafilococcus coagulase negativa, Stafilococcus aureus, Pseudomonas aeruginosas e Acinetobacter. Esse resultado corrobora com os resultados do estudo onde se obtiveram amostras com pouca redução de bactérias ou até mesmo sem redução após a higiene com álcool $70 \%$ em leitos hospitalares ${ }^{(95)}$.

Tal achado no presente estudo vem ao encontro de pesquisas sobre desinfetantes em ambiente odontológico onde observaram a redução significativa de microrganismos com o uso do álcool etílico 70\% líquido, embora refiram não ser também o melhor desinfetante testado ${ }^{(91,92)}$.

O álcool 70\% segundo o Ministério da Saúde pode ser utilizado para a descontaminação de superfícies do hospital ${ }^{(71)}$ e é amplamente utilizado em atividades como higienização da pele e utensílios em geral principalmente por seu baixo custo, facilidade de aquisição, baixa toxicidade, estabilidade no 
armazenamento, ser incolor, evaporar sem deixar resíduos e por ser mais divulgado nas pesquisas microbiológicas ${ }^{(91,92,95)}$.

Estudo analisando os derivados de fenóis utilizados em limpeza afirma que seu efeito é reduzido quando há a presença de matéria orgânica e que sua ação é menos ativa em fungos e esporos ${ }^{(95)}$.

Quanto à análise do antisséptico hipoclorito 1\% "in vitro" neste estudo, achou-se que esse produto apresentou pouca sensibilidade em relação ao álcool $70 \%$, clorexidina degermante $2 \%$ e clorexidina alcoólica $2 \%$. Tal resultado vem corroborar com estudo realizado com a limpeza dos estetoscópios em um hospital na área pediátrica onde conclui que o hipoclorito reduziu a quantidade de bactérias, porém o álcool etílico $70 \%$ foi mais eficaz ${ }^{(88)}$, assim como no presente estudo.

Ao analisar a sensibilidade da água e sabão "in vitro" frente às bactérias isoladas no estudo, percebeu-se resistência bacteriana. Tal achado acorda com o achado de estudo anterior sobre a higiene dos banheiros, comparando os produtos álcool 70\%, hipoclorito 1\% e a mistura água e sabão "in vivo" onde concluiu que o álcool $70 \%$ e o hipoclorito apresentaram resultado significante na redução de bactérias enquanto a água com sabão apresentou ineficiência na proposta ${ }^{(96)}$.

Os achados desse estudo "in vitro" independente do produto de higiene utilizado e pesquisado vêm ao encontro dos resultados de sensibilidade dos produtos frente às bactérias isoladas apesar da ação mecânica e da ação residual do produto quando utilizado "in vivo" $(95,97)$. 
6. Canclusães 


\section{CONCLUSÕES}

$\checkmark \quad$ Há crescimento bacteriano nas mãos das crianças em idade préescolar e escolar,

$\checkmark$ Há crescimento bacteriano no brinquedo imediatamente após a brincadeira e depois do processo de higienização com álcool 70\%,

$\checkmark$ Há predomínio do crescimento bacteriano, nas mãos e no brinquedo, da bactéria Stafilococcus coagulase negativa em todos os momentos de coleta,

$\checkmark \quad$ Nas coletas do brinquedo, o maior percentual de crescimento bacteriano é no momento imediato após a brincadeira,

$\checkmark \quad$ A maioria das bactérias isoladas nas amostras das mãos e do brinquedo é sensível ao antibiótico Oxacilina,

$\checkmark \quad$ Quanto à sensibilidade "in vitro" dos produtos de higiene frente à bactéria isolada, nas amostras das mãos e do brinquedo, a clorexidina alcoólica $2 \%$ é a mais sensível, seguida da clorexidina degermante $2 \%$.

$\checkmark \quad$ O álcool 70\% e o hipoclorito de sódio 1\% apresentam pouca sensibilidade "in vitro" frente às bactérias isoladas das amostras das mãos e do brinquedo,

$\checkmark \quad$ A água e sabão comum são resistentes frente às bactérias isoladas nas amostras das mãos e do brinquedo,

$\checkmark \quad$ O brinquedo pode ser veículo na transmissão de microrganismo. 
7. Cansideraçães Finais 


\section{CONSIDERAÇÕES FINAIS}

$\checkmark \quad$ Com a diversidade de produtos químicos disponíveis hoje no mercado, há a necessidade de estudos e pesquisas para transparecer os benefícios de cada um, além de investimentos e treinamentos para os profissionais de saúde que aplicam essas técnicas e utilizam esses produtos,

$\checkmark$ Anseia-se que os resultados encontrados nesse estudo fundamentem decisões com a intenção de melhorias e existência de rotinas nos ambientes hospitalares, visando à diminuição de riscos aos pacientes durante sua internação,

Visando à garantia da brincadeira segura com brinquedos de plástico, sugere-se nesse estudo:

- Recomendações sobre a higienização dos brinquedos, - Descrição do processo de higienização dos brinquedos. 


\section{RECOMENDAÇÕES SOBRE A HIGIENIZAÇÃO DOS BRINQUEDOS E DESCRIÇÃO DO PROCESSO DE HIGIENIZAÇÃO DOS BRINQUEDOS DE PLÁSTICO EM UNIDADE DE INTERNAÇÃO PEDIÁTRICA}

Os brinquedos deverão ser higienizados nos horários:

- 08 horas, 12 horas e às 18 horas.

Quando ocorrer de o brinquedo ser retirado da brinquedoteca, ele deverá ser higienizado antes de retornar à brinquedoteca e também antes de ser entregue à outra criança,

Ao final das brincadeiras, os brinquedos deverão ser colocados em caixa de plástico para a realização das limpezas e desinfecções antes de serem armazenados.

\section{Definições:}

Limpeza- processo de remoção da sujeira mediante ação mecânica, química ou térmica num determinado tempo ${ }^{(52)}$;

Desinfecção- processo de destruição de microrganismos patogênicos na forma vegetativa, mediante ação física ou química ${ }^{(52)}$.

\section{Brinquedos de uso comunitário:}

1. Lavar o material com água e sabão em pia destinada para essa utilização,

2. Enxaguar em água corrente e deixar secar, 
3. Friccionar com um pano ou uma compressa limpa o brinquedo com a clorexidina alcoólica $2 \%$,

4. Deixar secar,

5. Armazenar em local seco e limpo.

\section{Brinquedos em contato com fluidos corporais ou em utilização de} pacientes sobre precauções especiais:

1. Lavar com água e sabão,

2. Enxaguar em água corrente,

3. Imergir em solução de hipoclorito * (1:10), por 10 a 20 minutos,

4. Remover e enxaguar,

5. Friccionar com um pano ou uma compressa limpa o brinquedo com a clorexidina alcoólica 2\%,

6. Deixar secar,

7. Armazenar em local seco e limpo.

*O hipoclorito 1\% é indicado para remover os fluidos corporais como o sangue ${ }^{(71,72)}$. 
8. Referências 


\section{REFERÊNCIAS}

1- Teixeira R. Breve reflexão sobre a história e o sentido atual dos hospitais da sociedade [Internet]. 2005 [acesso 02 Fev 2009]. Disponível em: http://www.hportugues.com.br/noticias/outras_ediçoes/folder.2005-02-03.53 03048370/docimagebig.2005-01-07.3844893676

2- Barros L. As consequências psicológicas da hospitalização infantil: prevenção e controle. Anal. Psicol. 1998; 1: 11-28.

3- Carvalho ES, Marques SR. Infecção hospitalar em Pediatria. J Pediatr. $1999 ; 75: 31-45$.

4- Lacerda RA. Produção científica nacional sobre infecção hospitalar e a contribuição da enfermagem: ontem, hoje e perspectivas. Rev Latino-am Enferm. 2002; 10:55-63.

5- Ministério da Saúde. DATASUS [Internet]. Brasília: Ministério da Saúde; 2004 [acesso 20 Jan 2009]. Disponível em: http://www.datasus.org.br

6- Mitre RMA, Gomes R. A perspectiva dos profissionais de saúde sobre a promoção do brincar em hospitais. Ciênc Saúde Coletiva. 2007; $12: 1277-84$.

7- Rodrigues AR, Pimentel HP, Barboti RA. Benefícios do brinquedo terapêutico no cuidado de enfermagem à criança hospitalizada [Internet]. [trabalho de conclusão de curso]. Santos: Universidade Paulista; 2008 [acesso 17 Set 2009]. Disponível em: www.webartigos.com/.../beneficiosdo-brinquedo-terapeutico...cuidado-de-enfermagem.../pagina1.html 
8- Furtado MCC, Lima RAG. Brincar no hospital: subsídios para o cuidado de enfermagem. Rev Esc Enferm USP. 1999; 33:364-9.

9- Ribeiro CA, Ângelo MO. O significado da hospitalização para a criança préescolar: um modelo teórico. Rev Esc Enferm USP. 2005; 39:391-400.

10- Martins MR, Ribeiro CA, Boraba RIH, Silva CV. Protocolo de preparo da criança pré-escolar para punção venosa, com utilização do brinquedo terapêutico. Rev Latino-am Enferm. 2001; 9:76-85.

11- Leite JA, Sandoval JMH. O brincar como estratégia comunicativa de promoção da saúde em crianças hospitalizadas [Internet]. [acesso 01 Jul 2008]. Disponível em: http://www.projetoradix.com.br/arq_artigo/VI_08.pdf

12- Schmitz SM, Piccoli M, Vieira CS. A criança hospitalizada, a cirurgia e o brinquedo terapêutico: uma reflexão para a enfermagem. Ciênc Cuid Saúde. 2003; 2:67-73.

13- Waksman RD, Harada MJCS. Escolha de brinquedos seguros para casa, ambulatório e hospital. Rev Paul Pediatr. 2005; 23:192-7.

14- Almeida FA. Brinquedo no hospital: em busca de evidências científicas para uma prática segura. In: Anais do $4^{\circ}$ Simpósio Internacional de Enfermagem; 2007; São Paulo. São Paulo: Einstein Instituto de Ensino e Pesquisa; 2007. v.5, p.S22.

15- Magalhães CMC, Pontes FAR. Criação e manutenção de brinquedotecas: reflexões acerca do desenvolvimento de parcerias. Psicol Reflex Crít. 2002; 15: $235-42$. 
16- Junqueira MFPS. O brincar e o desenvolvimento infantil. Psicologia em Pediatria [Internet]. [acesso 02 Jul 2008]. Disponível em: http://www. moreirajr.com.br/pediatriamoderna/ped1299/pedbrincar.htm

17- Françani GM, Zilioli D, Silva PR, Santana RPM, Lima RAG. Prescrição do dia: infusão de alegria. Utilizando a arte como instrumento na assistência à criança hospitalizada. Rev Latino-am Enferm. 1998; 6: 27-33.

18- Santos SMP. Brinquedoteca hospitalar [Internet]. [acesso 26 Maio 2008]. Disponível em: www.agab.com.br

19- Mitre RMA, Gomes R. A promoção do brincar no contexto da hospitalização infantil como ação de saúde. Ciênc Saúde Colet. 2004; 9:147-54.

20- Motta AB, Enumo SRF. Brincar no hospital: estratégia de enfrentamento da hospitalização infantil. Psicol Estud. 2004; 9:19-28.

21- Ribeiro CA. O brinquedo terapêutico na assistência à criança hospitalizada: significado da experiência para o aluno de graduação em enfermagem. Rev Esc Enferm USP. 1998; 32:73-9.

22- Paula EMAT, Foltran EP. Brinquedoteca hospitalar: direito das crianças e adolescentes hospitalizados [Internet]. [acesso 10 Ago 2008]. Disponível em: www.uepg.br/revistaconexao/revista/edicao03/artigo4.pdf

23- Ministério da Saúde. Portaria n. 2261. Aprova o Regulamento que estabelece as diretrizes de instalação e funcionamento das brinquedotecas nas unidades de saúde que ofereçam atendimento pediátrico em regime de internação. Diário Oficial. 24 Nov. 2005; Sec. 1, n. 225. 
24- Sabates AL. O brinquedo como instrumento na assistência de enfermagem à criança hospitalizada. In: Trabalho apresentado no $1^{\circ}$ Congresso Paulista de Enfermagem Pediátrica; 1995; São Paulo. São Paulo. p.37-52.

25- Cibreiros SA. A comunicação do escolar por intermédio dos brinquedos: um enfoque para a assistência de enfermagem nas unidades de cirurgia pediátrica. Rio de Janeiro: Editora da UFRJ; 2001.p.50-61.

26- Cintra SMP, Silva CV, Ribeiro CA. O ensino do brinquedo/brinquedo terapêutico nos cursos de graduação em enfermagem no Estado de São Paulo. Rev Bras Enferm. 2006,59: 497-501.

27- Petrillo M, Sanger S. Cuidado emocional del nino hospitalizado. México: La Prensa Medica Mexicana; 1972: v.5, p.111-49.

28- Conselho Regional de Enfermagem de São Paulo. Principais legislações para o exercício da enfermagem. São Paulo: Demais Editoração e Publicação; 2003.

29- Pinto JP, Fernandes RAQ, Teixeira M. A mãe e a punção venosa do filho hospitalizado: uma visão fenomenológica. Rev Paul Enferm. 2001; 20:12-9.

30- Pinto JP, Ribeiro CA, Silva CV. Procurando manter o equilíbrio para atender suas demandas e cuidar da criança hospitalizada: a experiência da família. Rev Latino-am Enferm. 2005; 13:974-81.

31- Freitas APCB, Silva MCF, Carvalho TC, Pedigone MAM, Martins CHG. Brinquedos em uma brinquedoteca: um perigo real? Rev Bras Anál Clín. 2007; 39: 291-4. 
32- Fernandes AT. Infecção hospitalar e suas interfaces na área da saúde. São Paulo: Atheneu; 2000. v.1.

33- Spaulding In, Cardoso MFS, Correa L, Medeiros ACT. A Higienização dos brinquedos no ambiente hospitalar. Rev Prát Hosp. 2005; 42:29-42.

34- Novaes LHVS, Isaacsson CB, Sandrini AH, Gruber C, Dalmora G, Gaspary LMB, et al. Brinquedo pode ser contagioso? Rev Paul Pediatr. 1997; $15: 77-81$.

35- Machado MB. Infecções hospitalares em Enfermaria de Pediatria. ANVISA. Pediatria: prevenção e controle de infecção hospitalar. Brasília; 2003. cap.5, p.63-75.

36- Glassy D, Romano J. Selecting appropriate toys for young children: the pediatrician's role. Pediatrics. 2003; 111:911-3.

37- Neves ZCP, Tipple AFV, Souza ACS, Pereira MS, Melo DS, Ferreira LR. Hand hygiene: the impact of incentive strategies on adherence among healthcare workers from a newborn intensive care unit. Rev Latino-am Enferm. 2006;14: 546-52.

38- Andrade D, Angerami ELS. Reflexões acerca das infecções hospitalares às portas do terceiro milênio. Medicina (Ribeirão Preto). 1999; 32: 492-7.

39- Souza ACS, Tipple AFV, Pereira MS, Prado MA. Desafios para o controle de infecção nas instituições de saúde: percepção dos enfermeiros. Ciênc Enferm. 2002; 8:19-30. 
40- Pereira MS, Souza ACS, Tipple AFV, Prado MA. A infecção hospitalar e suas implicações para o cuidar da enfermagem. Texto Contexto Enferm. $2005 ; 14: 25-7$.

41- Ministério da Saúde. Portaria $n^{\circ}$ 2616, de 12 de maio de 1998. Resolve expedir, na forma dos anexos I, II, III, IV e V, diretrizes e normas para a prevenção e o controle das infecções hospitalares, ficando revogada a portaria n 930. Diário Oficial da União; 13 Maio 1998. Sec. 1, p. 133-5.

42- Ministério da Saúde. Manual de controle de infecção hospitalar. Brasília: Centro de Documentação Científica do Ministério da Saúde; 1985. p.123.

43- Andrade D, Angerami ELS, Padovani CR. Condição microbiológica dos leitos hospitalares antes e depois de sua limpeza. Rev Saúde Pública. 2000; 34:163-9.

44- Fontana RT. As infecções hospitalares e a evolução histórica das infecções. Rev Bras Enferm. 2006; 59:703-6.

45- Sousa CMM, Feitosa MS, Moura MEB, Silva AO. Representações Sociais das implicações legais da infecção hospitalar e de seu controle. Rev Bras Enferm. 2007; 60:428-33.

46- Vasconcelos MAA, Castro AMV, Queiroz ALM, Araújo ELB, Nascimento GSM, Jesus IA, et al. Análise microbiológica de indústrias alimentares do município de João Pessoa - PB [Internet]. In: Anais do $10^{\circ}$ Encontro de Iniciação à Docência; 2008; João Pessoa. João Pessoa; 2008 [acesso 20 Mar 2009]. Disponível em: www.ufpb.br 
47- Ansari S. In vivo protocol for testing efficacy of hand-washing agents against viruses and bacteria: experiments with Rotavirus and Escherichia coli. Appl Environ Microbiol. 1989; 551:3113-8.

48- Correa I, Ranali J, Pignatari ACC. Observação do comportamento dos profissionais em relação ao procedimento da lavagem das mãos no plano assistencial à criança internada. Rev Téc Enferm Nursing. 2001; 4:18-21.

49- Correa I. Avaliação do procedimento da lavagem das mãos no plano assistencial à criança portadora de diarréia aguda bacteriana [tese]. Campinas: Universidade Estadual de Campinas; 1995.

50- Correa I, Ranali, J, Pignatari ACC. Avaliação da eficácia de dois produtos comerciais utilizados na lavagem das mãos no hospital das clinicas. Rev Téc Enferm Nurs. 2005; 52:15-21.

51- Haley RW, Garner JS. Infection surveillance and control programs. In: Bennett JV, Brachmann PS. Hospital infections. Boston: Little \& Brown; 1986. p. 39-50.

52- Cardoso MFS, Correa L, Medeiros ACT. A higienização dos brinquedos no ambiente hospitalar. Rev Prat. Hosp. 2005; 42:29-42.

53- Alves DCI, Évora YDM. Questões éticas envolvidas na prática profissional de enfermeiros da comissão de controle de infecção hospitalar. Rev Latinoam Enferm. 2002; 10:265-75. 
54- Tiplle AFV, Pereira MS, Hayashida M, Moriya TM, Souza ACS. O ensino do controle de infecção: um ensaio teórico-prático. Rev Latino-am Enferm. 2003; 11:245-50.

55- Bolick D. Segurança e controle de infecção. Rio de Janeiro: Reichmann \& Affonso Editores; 2000. p.105.

56- Costa SB, Pelli A, Carvalho GP, Oliveira AG, Silva PR, Teixeira MM e et al. Formigas como vetores mecânicos de microrganismos no Hospital Escola da Universidade Federal do Triângulo Mineiro. Rev Soc Bras Med Trop. 2006; 39: 527-9.

57- Araujo AA, Rocha CS, Soares GMV. O papel das formigas carreadoras de microrganismos patogênicos no ambiente hospitalar. In: Anais do $22^{\circ}$ Congresso Brasileiro de Microbiologia; 2003; Florianópolis, Florianópolis; 2003.p.240.

58- Ministério da Saúde. Secretaria Executiva. Subsecretaria de Assuntos Administrativos. Coordenação-Geral de Documentação. Estatuto da Criança e do Adolescente [Internet]. 3a ed. Brasília; 2006 [acesso 02 Ago 2009]. Disponível em: www.promenino.org.br

59- Agência Nacional de Vigilância Sanitária. Resolução de Diretoria Colegiada. RDC 50, de 21 de fevereiro de 2001. Dispõe sobre regulamento técnico para planejamento, programação, elaboração e avaliação de projetos físicos de estabelecimentos assistenciais de saúde [Internet]. Brasília; 2001 [acesso 02 Abr 2009]. Disponível em: http://www.anvisa.gov.br/legis/resol/2002/307_02rdc.htm 
60- Posfay-Barbe KM, Zerr DM, Pittet D. Infection control in pediatrics. Lancet Infect Dis. 2008; 8:19-31.

61- Hanrahan KS, Lofgren M. Evidence-based practice: examining the risk of toys in the microenvironment of infants in the neonatal intensive care unit. Adv Neonatal Care. 2004;4:184-201.

62- Ferrareze MVG, Leopoldo VC, Andrade D, Silva MFI, Haas VJ. Pseudomonas aeruginosa multiresistente em unidade de cuidados intensivos: desafios que procedem? Acta Paul Enferm. 2007; 20:7-11.

63- Pereira MG. Epidemiologia: teoria e prática. Rio de Janeiro: GuanabaraKoogan; 2001. cap.12, p.269-88.

64- Potter PA, Perry AG. Grande tratado de Enfermagem Prática: conceitos básicos, teoria e prática hospitalar. 3ª ed. São Paulo: Santos; 1998.

65- Davies MW, Mehr S, Garland ST, Morley CJ. Bacterial colonization of toys in neonatal intensive care cots. Pediatrics. 2000; 106:01-5.

66- McNemar Q. Nota sobre o erro de amostragem da diferença entre proporções correlacionadas ou porcentagens. Psychometrika. 1947; 2:153-57.

67- Coletânea de Regimentos do Hospital Estadual Bauru. Parte I - Regimento Geral do Hospital Estadual Bauru: Hospital Estadual Bauru: 2004. p. 7-9. 
68- Centers For Disease Control. Recommendations for prevention of HIV transmission in health-care settings [Internet]. Atlanta: CDC; 2009 [acesso 17 Set 2009]. Disponível em: http://www.cdc.gov/mmwr/

69- Instituto Nacional de Metrologia, Normalização e Qualidade Industrial [Internet]. Segurança de brinquedos: com esse assunto não se brinca. Brasília: Inmetro; 2009 [acesso 17 Set 2009]. Disponível em: http://www.inmetro.gov.br/noticias/conteudo/cartilha1.htm

70- Braz ACG, Corrêa I. Higienização das brinquedotecas no controle de transmissão de microrganismos. Braz Infect Dis. 2008; 12:213.

71- Ministério da Saúde. Coordenação de Controle de Infecção Hospitalar. Processamento de artigos e superfícies em estabelecimentos de saúde. 2ed. Brasília; Ministério da Saúde; 1994. 50 p.

72- Réus M. Biosegurança em consultório odontológico. Revista Racine. 2002. [Internet]. [acesso 14 de Jan 2010]. Disponível em: www.racine.com.br

73- Almeida KB, Jorge AOC. Avaliação de desinfecção de superfície em cadeira odontológica. Rev Biociênc. 2002; 8:19-2.

74- Bier O. Bacteriologia e imunologia. 20a ed. São Paulo: Melhoramentos; 1984.

75- Andrade GM. Proposta de diretrizes nacionais para política de antimicrobianos: Programa Nacional de Controle de Infecção em Serviços de Saúde [Internet]. Brasília: Agência Nacional de Vigilância Sanitária; 2002. [acesso 14 Jan 2010]. Disponível em: www.anvisa.gov.br/ servicosaude/controle/aula_1.ppt 
76- Francisco MF, Machado YL, Dipe VC. Higienização das crianças da educação infantil na escola municipal Sagrado Coração de Jesus. In: Congresso Paulistano de Educação Física Escolar. [Internet]; 22-24 jul 2009; Caraguatatuba: Centro Universitário módulo; 2009. [acesso 14 Jan 2010]. Disponível em: www.efescolar.pro.br/Arquivos/arq_2009_21.pdf

77- Nesti MMM, Goldbaum M. As creches e pré-escolares e as doenças transmissíveis. J Pediatr. 2007; 83:299-312.

78- Santos IBC, Filho LS, Xavier DE. Investigação sobre colonização bacteriana de mãos de profissionais de enfermagem. Rev SOBECC. 2004; 2:29-34.

79- Health Latin America. A importância da higiene como melhoria na qualidade de vida das crianças [Internet]. Belo Horizonte: Bibliomed Inc; 2010 [acesso 14 Jan 2010]. Disponível em: www.boasaude.com.br.

80- Teixeira P. Crianças não sabem lavar as mãos corretamente [Internet]. [acesso 14 Jan 2010]. Disponível em: http://jornal.publico.clix.pt/ noticias. $\operatorname{asp} ? \mathrm{a}=2006 \& \mathrm{~m}=07 \& d=31 \& u i d=\& i d=91632 \& \operatorname{sid}=9993$

81- Criança. In: Wikipédia: a enciclopédia livre [Internet]. [acesso 14 Jan 2010]. Disponível em:http://pt.wikipedia.org/wiki/Crian\%C3\%A7a

82- Enciclopédia Ilustrada de Saúde. [Internet]. [acesso 14 jan 2010]. Disponível em: http://adam.sertaoggi.com.br/encyclopedia/index.htm

83- Queiroz MJA, Alves JGB, Correia JB. Leishmaniose visceral: características clínico-epidemiológicas em crianças de área endêmica. J Pediatr. 2004; 2:141-6. 
84- Junior FC, Nunes EWF, Nascimento ED, Oliveira SM, Melo MCN, Fernandes MJBC. Prevalência de Staphylococcus spp resistentes à meticilina isolados em uma maternidade escola da Cidade de Natal, Estado do Rio Grande do Norte. Rev Soc Bras Med Trop. 2009; 42:179-82.

85- Buttery JP, Alabaster SJ, Heine RG, Scott SM, Crutchfield RA, Bigham A, et al. Multiresistant Pseudomonas aeruginosa outbreak in a pediatric oncology ward related to bath toys. Pediatr Infect Dis J. 1998; 17: 509-13.

86- PR. Vade-mécum Brasil. 2005/2006 [Intranet]. [acesso 14 Jan 2010]. Disponível em: file://C:\Arquivos de programaslEurofarmalPR2Klpr.htm

87- Cunha MLRS, Lopes CAM. Estudo da produção de b-lactamase e sensibilidade às drogas em linhagens de estafilococos coagulase-negativos isolados de recém-nascidos. J Bras Patol Med Lab. 2002; 38:281-90.

88- Xavier MS, Ueno M. Contaminação bacteriana de estetoscópios das unidades de pediatria em um hospital universitário. Rev Soc Bras Med Trop. 2009; 42:217-8.

89- Jones RN. Impact of changing pathogens and antimicrobial susceptibility patterns in the treatment of serious infections in hospitalized patients. Am J Med.1996; 100:1-12.

90- Fowler JL, Schuh JCL. Preoperative chemical preparation of the eye a comparison of chlorhexidine diacetate, chlorhexidine gluconate, and povidone-iodine. J Am Anim Hos Assoc. 1992; 28: 451-7. 
91- Silva CRG, Jorge AOC. Avaliação de desinfetantes de superfície utlizados em Odontologia. Pesquisa Odontol. Bras. 2002; 2:107-14.

92- Bambace AMJ, Barros EJA, Santos SSF, Jorge AOC. Eficácia de soluções aquosas de Clorexidina para desinfecção de superfícies. Rev Biociênc. 2003; 9:73-81.

93- Padovani CM, Graziano KU, Goveia VR. Avaliação microbiológica das diferentes formulações anti-sépticas, polivinilpirrolidona-iodo e clorexidina, após contaminação intencional das almotolias. Rev Latino-Am Enferm. $2008 ; 16: 1038-41$.

94- Avila-Aguero ML, German G, Paris MM, Herrera JF. Toys in a pediatric hospital: are they a bacterial source? Am J Infect Control. 2004; 32:287-90.

95- Andrade D, Ferrareze MVG, Santos LS, Moraes CM, Freire E, Ito IY. Uso de sabões e detergentes em serviços de saúde: novos contextos, outros olhares? Rev Panam Infectol. 2006; 8:33-7.

96- Scott E, Bloomfield SF. A bacteriological investigation of the effectiveness of cleaning and disinfection procedures for toilet hygiene. J Appl Bacteriol. 1985;59:291-7.

97- Souza ACS, Pereira MS, Rodrigues MAV. Descontaminação prévia de materiais médico-cirúrgicos: estudo da eficácia de desinfetantes químicos e água e sabão. Rev Latino-am Enferm. 1998; 6:95-105. 
9. Anexas 


\section{ANEXOS}

Anexo 1- Formulário A: Variável Dependente e Variáveis Complementares.

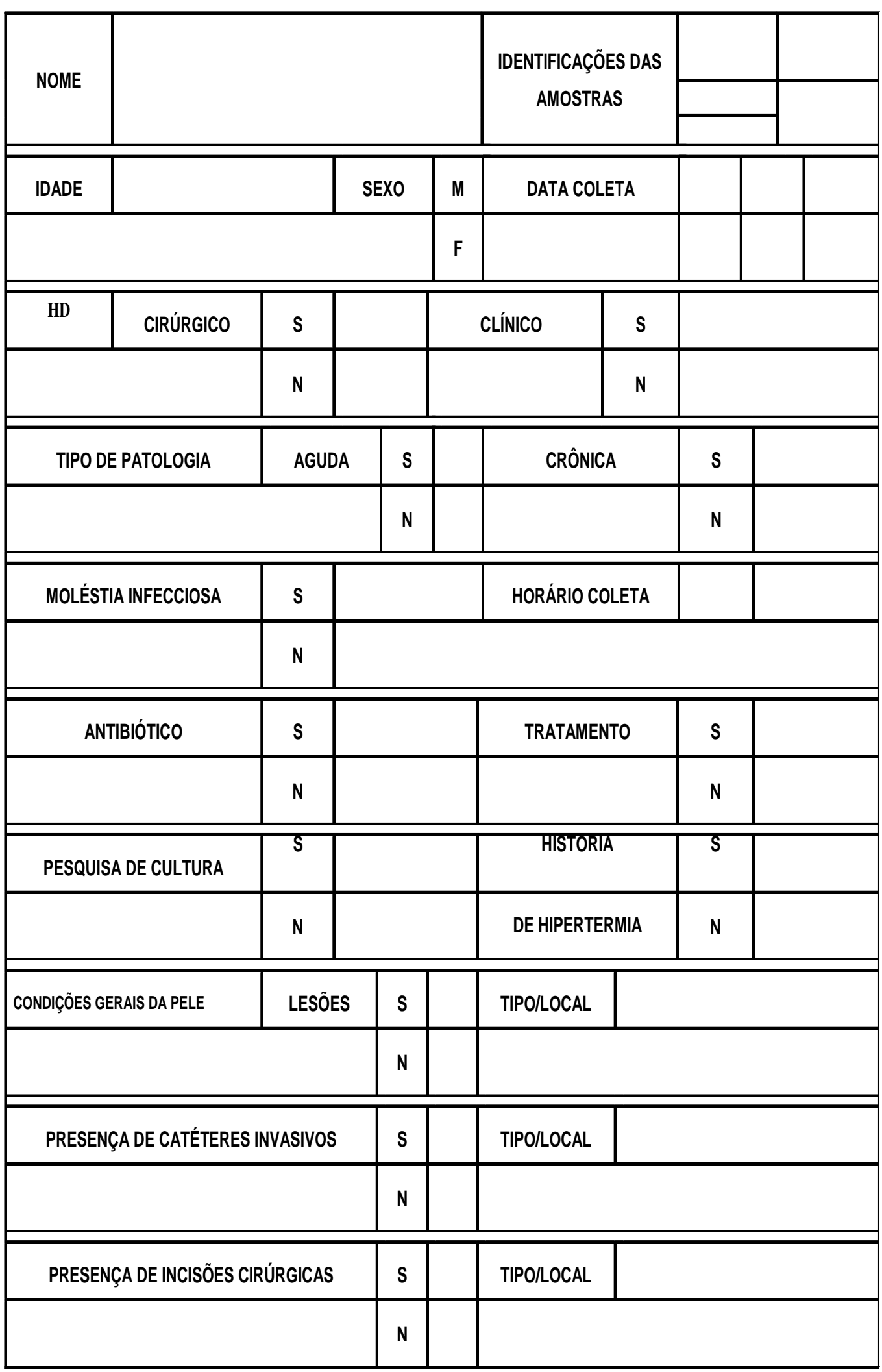


Anexo 2 - Formulário B: Variáveis da análise bacteriana - Mãos e Brinquedos.

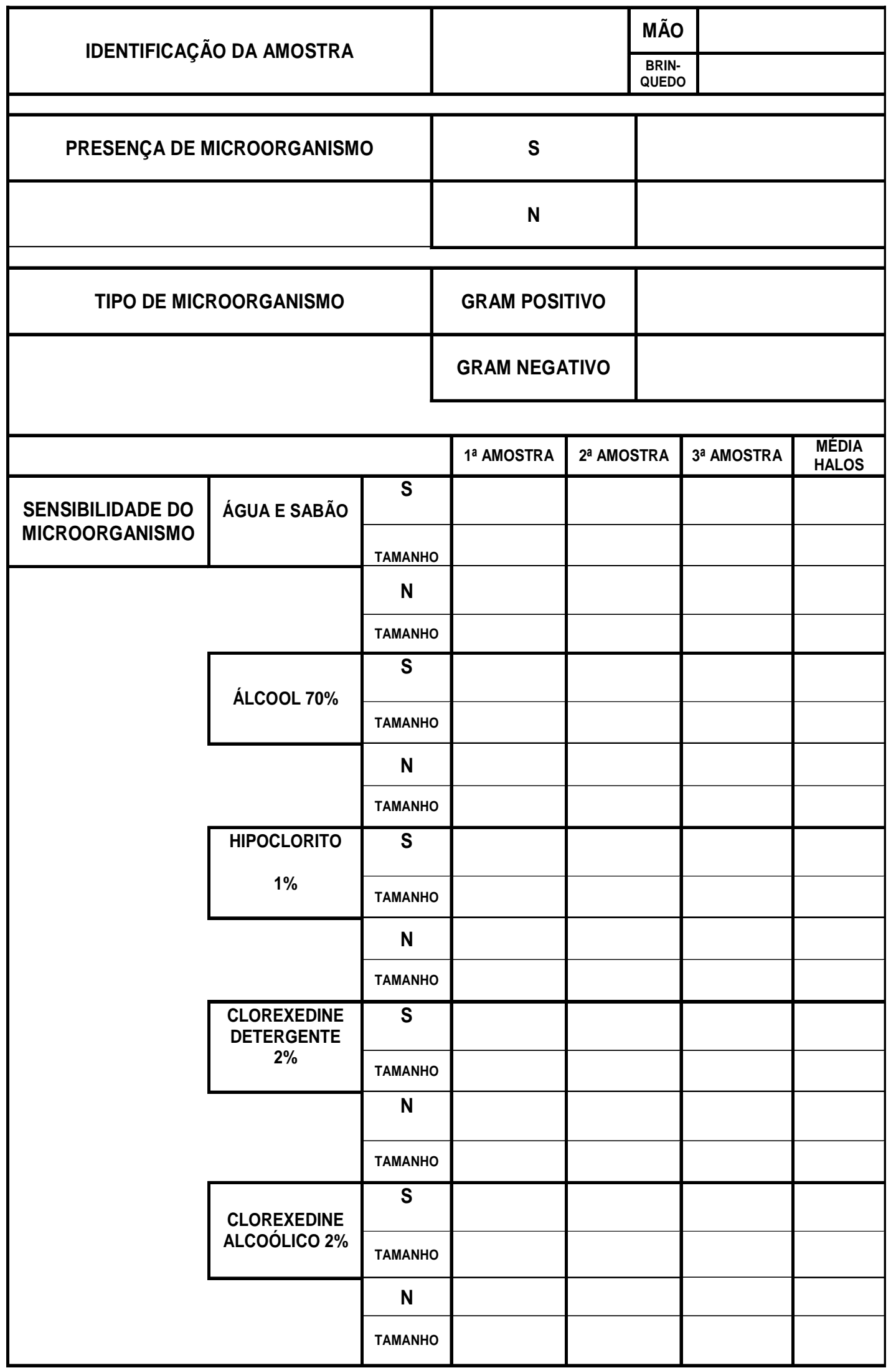


10. Apêndices 


\section{APÊNDICES}

APÊNDICE 1 - Termo de Consentimento Livre e Esclarecido.

\section{Termo de Consentimento Livre e Esclarecido}

Você está sendo convidada (o) a participar de um projeto de pesquisa, que tem como titulo "Condições bacteriológicas de brinquedos em uma Unidade de Pediatria", realizado pela Enfermeira Marcela C. Candido de Almeida, sob orientação da Prof ${ }^{\mathrm{a}}$ Ass. $\operatorname{Dr}^{\mathrm{a}}$ Ione Corrêa.

Este projeto de pesquisa tem como objetivo geral avaliar as condições microbiológicas dos brinquedos de plástico utilizados na Unidade de Pediatria do Hospital Estadual de Bauru, identificando os microrganismos nos brinquedos e avaliando a eficácia da higienização desses brinquedos utilizados nas atividades e brincadeiras.

Sendo você responsável por uma criança que utiliza esse brinquedo, peço autorização para realizar a pesquisa e caso concorde, solicito que assine o termo de consentimento. Fica claro que o responsável pela criança participante pode a qualquer momento retirar seu consentimento livre e esclarecido e deixar de participar desta pesquisa, sem interferir no tratamento e cuidados da criança.

Informo que não haverá nenhum marcador ou identificador na criança observada.

Declaro que o presente projeto de pesquisa foi explicado em detalhes quanto ao seu desenvolvimento e após aprovação do Comitê de Ética em Pesquisa da Faculdade de Medicina de Botucatu, será elaborado em duas vias, sendo uma cópia entregue ao sujeito da pesquisa e outra será mantida em arquivo pelo pesquisador.

Tendo sido satisfatoriamente informada sobre a pesquisa concordo em participar da mesma.

Bauru, 1

Responsável pelo Paciente

Marcela C. C. de Almeida 


\section{APÊNDICE 2 - Parecer de concordância do Comitê Científico do Hospital Estadual de Bauru.}

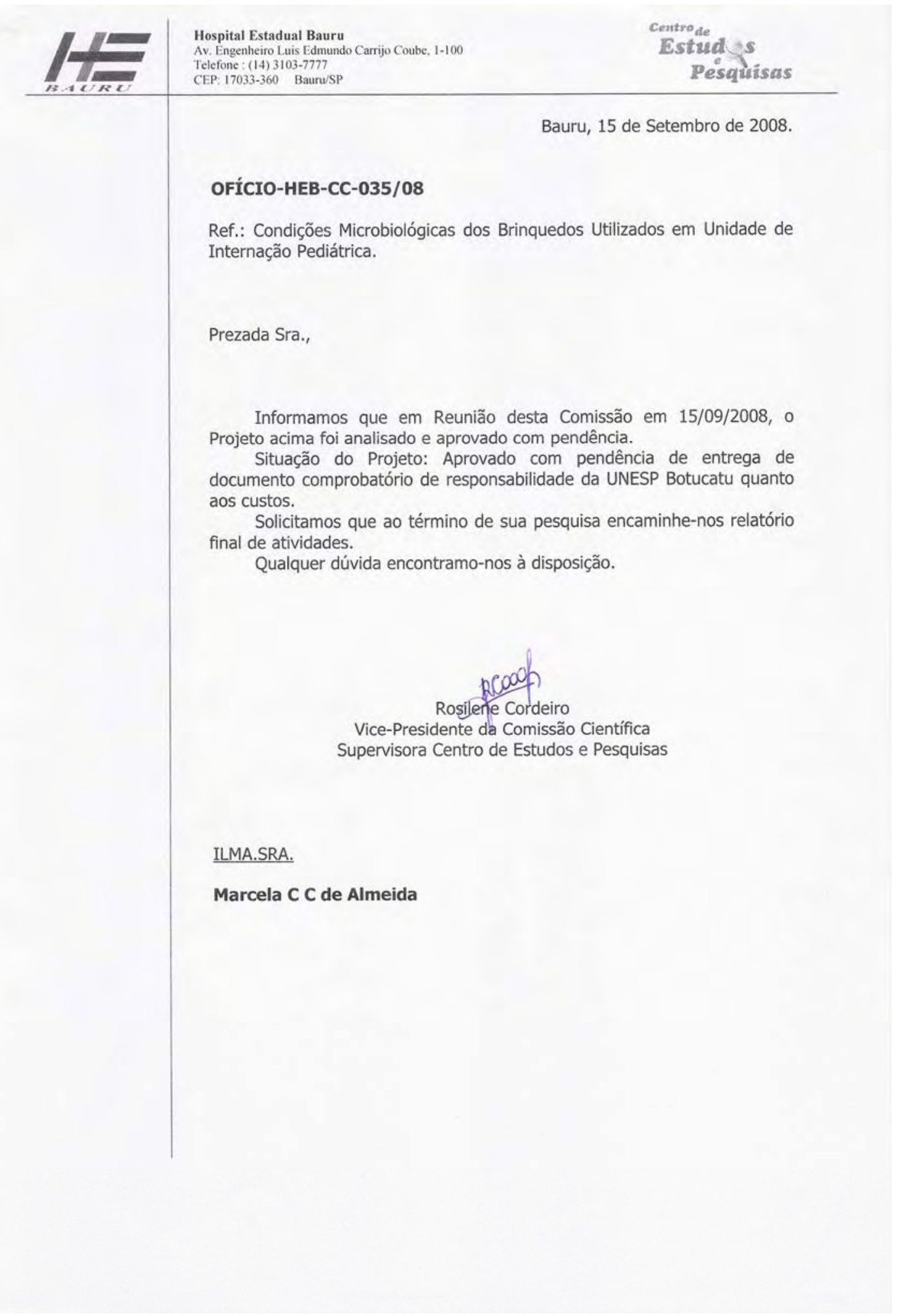




\section{APÊNDICE 3 - Parecer de concordância do Comitê Científico do Hospital} Estadual de Bauru.

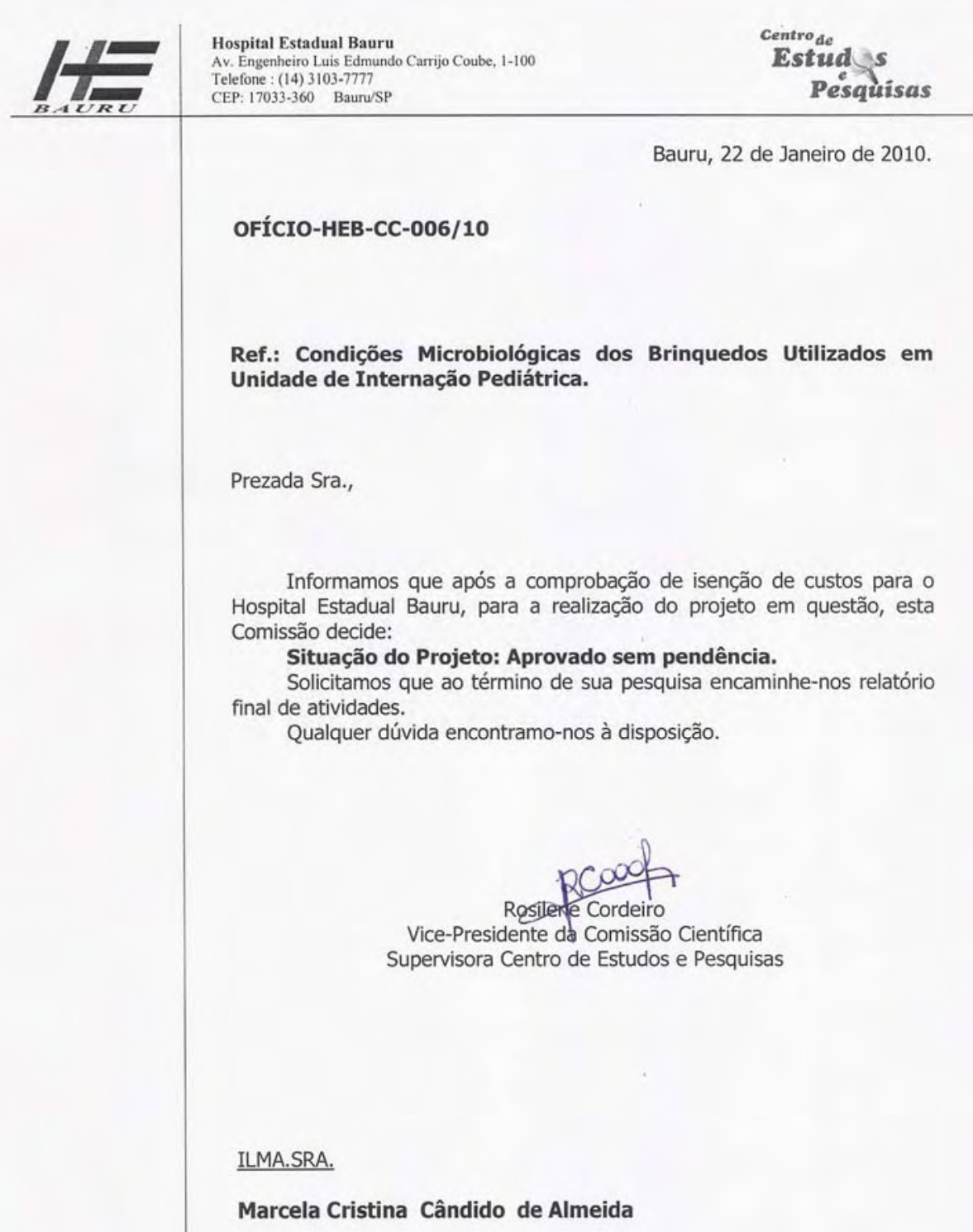




\section{APÊNDICE 4 - Parecer de aprovação do Comitê de ética da Faculdade de Medicina de Botucatu.}

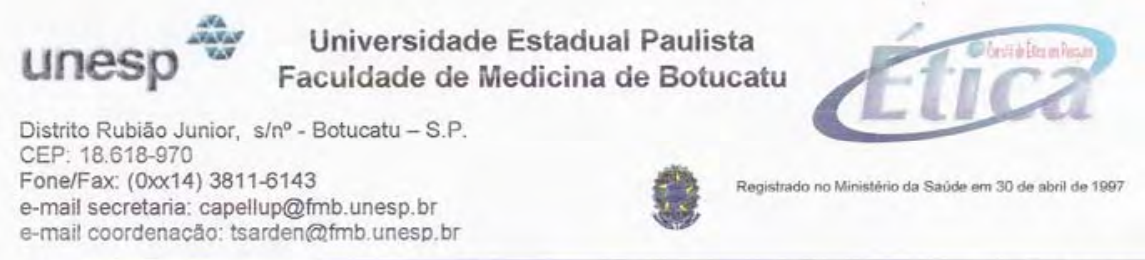

Botucatu, 06 de outubro de 2008

Of. 431/08-CEP

Ilustríssima Senhora

Prof ${ }^{a} D r^{a}$ Ione Corrêa

Departamento de Enfermagem da

Faculdade de Medicina de Botucatu.

Prezada Dra Ione,

De ordem do Senhor Coordenador deste CEP, informo que o Projeto de Pesquisa "Condições microbiológicas dos brinquedos utilizados em uma unidade de internação pediátrica", a ser conduzido por Marcela Cristina Candido de Almeida, orientada por Vossa Senhoria, recebeu do relator parecer favorável aprovado em reunião de 06 de outubro de 2.008.

Situação do Projeto: APROVADO. Apresentar Relatório Final de Atividades ao final da execução deste projeto.

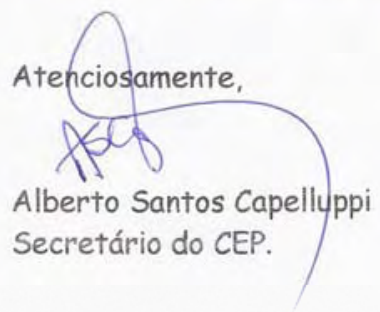


APÊNDICE 5 - Justificativa de alteração no título do projeto de pesquisa.

\section{unesp}

DIVISÃO TECNICA ACADEMICA
UNIVERSIDADE ESTADUAL PAULISTA

CÂMPUS DE BOTUCATU

FACULDADE DE MEDICINA

Seçãa de Pós-Graduaçãa
Fis.

Proc

Rub.

BOTUCATU, SP - RUBIÃO JÚNIOR - CEP 18618-970 - PABX (0x×14) 3811-6022

JUSTIFICATIVA DE ALTERAÇÃO NO TITULO DO PROJETO DE PESQUISA

Declaramos que o Projeto de Pesquisa "Condiçós microbiológicass dos brinquedor utilizados um uma unidade de inter nagas pediátuca " aprovado pelo CEP em 06/10/08, teve seu título alterado para "Descriças bacteriológica de brinquedo utili zado em unidade de inter nacas pediátrica "sem nenhuma alteração no seu contecido metodológico da época de apresentação para análise do CEP.

A presente alteração foi efetuada somente para ạdequação do títuio da Dissertação de Mestrado.

Botucatu, $15,01,2010$

NomerAssinatura do(a) aiuno(a) Marcela e e de thmeida.

Nome/Assinatura do(a) orientador (a)

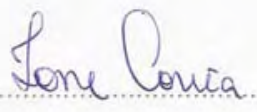

Programa de Pós Graduação em Enfum ... Enagem........

Preencher formulário em 2 vias e protocolar no respectivo CEP 